GIANCARLO OBANDO DIAZ

\title{
ANÁLISE DE SISTEMAS PARA O RESFRIAMENTO DE LEITE EM FAZENDAS LEITEIRAS COM O USO DO BIOGÁS GERADO EM PROJETOS MDL
}

Dissertação apresentada à Escola Politécnica da Universidade de São Paulo como requisito para obtenção do Título de Mestre em Engenharia.

São Paulo

2006 


\section{ANÁLISE DE SISTEMAS PARA O RESFRIAMENTO DE LEITE EM FAZENDAS LEITEIRAS COM O USO DO BIOGÁS GERADO EM PROJETOS MDL}

Dissertação apresentada à Escola Politécnica da Universidade de São Paulo como requisito para obtenção do Título de Mestre em Engenharia.

Área de concentração:

Engenharia Mecânica

Orientador:

Flávio Augusto Sanzovo Fiorelli

São Paulo 
Este exemplar foi revisado e alterado em relação à versão original, sob responsabilidade única do autor e com a anuência de seu orientador.

São Paulo, 01 de novembro de 2006.

Assinatura do autor

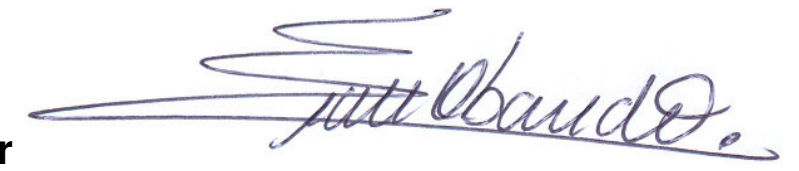

Assinatura do orientador

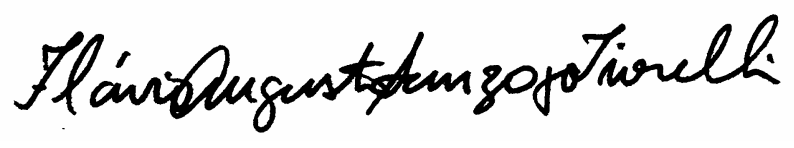

\section{FICHA CATALOGRÁFICA}

Obando Diaz, Giancarlo

Análise de sistemas para o resfriamento de leite em fazendas leiteiras com o uso do biogás gerado em projetos MDL / G.

Obando Diaz. -- ed.rev. --São Paulo, 2006.

$144 \mathrm{p}$.

Dissertação (Mestrado) - Escola Politécnica da Universidade de São Paulo. Departamento de Engenharia Mecânica.

1. Desenvolvimento rural 2. Tratamento de dejetos animais 3. Biodigestores 4. Biogás (Uso) 5 . Geração de energia elétrica 6. Projeto MDL I. Universidade de São Paulo. Escola Politécnica. Departamento de Engenharia Mecânica II. t. 
A mis padres les dedico el fruto de mi esfuerzo y la satisfacción depositada en esta disertación, con ella culmina una etapa más de mi vida. 


\section{AGRADECIMENTOS}

Hago extensivo mi agradecimiento a todas las personas que contribuyeron directa o indirectamente en esta etapa de mi vida. Gracias Paul por haberme incentivado y apoyado desde el inicio. Gracias Prof. Silvio de Oliveira Jr., por abrirme una puerta en esta prestigiosa Universidad y con eso la oportunidad de superación profesional. Gracias Prof. Fiorelli, por la confianza que depositó en mi, su apoyo fué fundamental en el inicio, el desarrollo y la culminación de este trabajo, gracias por todo Profesor. Agradezco también, a la Coordenação de Aperfeiçoamento de Pessoal de Nível Superior (CAPES) por el apoyo financiero.

El amor, apoyo y confianza que mi familia deposita en mi constituyen, sin duda alguna, la pieza fundamental de cada uno de mis logros, como el que hoy conmemoro junto a ellos. Gracias a mis padres por siempre creer en mi, gracias hermanos por su fuerza y alegría, gracias mamá Juana, por el amor, la fuerza y el ejemplo que cada día me transmites. A mis tíos Silvana y tío Rensso, les agradezco por velar mis pasos. En general, a toda mi familia, les agradezco por todo, gracias chibolo, porque siempre puedo contar contigo.

El Brasil me dió muchas alegrías y satisfacciones, dentro de esas me permitió conocer muy buenas personas, que hoy puedo considerarlos mis amigos, dentro de esas personas debo destacar el apoyo, la amistad y cariño de mi gran amigo Izeds, sin él, culminar esta etapa no hubiese sido posible, de la misma forma, hago extensivo este agradecimiento a su familia, cuyas oraciones y consejos me permitieron mantener la calma cuando la nostalgia e la inseguridad me invadían. Pero sobretodo, este país maravilloso me permitió conocer a una persona muy especial, Erika, mi enamorada, la que me brindó, además de amor y respeto, la fuerza para luchar y continuar luchando en esta vida llena de desafíos, a ti te agradezco por todo. 


\section{RESUMO}

O setor leiteiro brasileiro é caracterizado por um grande número de produtores, que, porém, apresentam baixos índices de produtividade e qualidade. Em relação à qualidade, é necessária a implantação de sistemas de resfriamento e conservação do leite na fazenda. Contudo, o investimento nesse tipo de equipamento é muitas vezes inviabilizado pelos baixos volumes de produção, bem como pela não disponibilidade de energia elétrica na área rural.

Nesse contexto, o objetivo deste trabalho é determinar qual a configuração ótima para o sistema de resfriamento de leite de uma fazenda leiteira de pequeno ou médio porte, que será inserida em um projeto de digestão anaeróbica no âmbito do Mecanismo de Desenvolvimento Limpo do Protocolo de Kyoto, implementado por uma empresa interessada na comercialização dos créditos de carbono.

Como esse projeto disponibilizará ao produtor um insumo energético renovável e de baixo custo (o biogás resultante da digestão), a determinação da configuração ótima considerou dois possíveis cenários: o de um produtor que ainda não conta com um sistema para resfriamento de leite in loco, e o de um produtor que já conta com esse sistema, acionado por energia elétrica, e estuda a viabilidade de investir na geração de energia usando o biogás na substituição da energia elétrica adquirida da rede pública de distribuição.

Foram analisados os aspectos técnicos ligados ao dimensionamento das configurações, avaliação do consumo dos diferentes insumos energéticos e quantificação dos créditos de carbono, bem como os aspectos econômicos envolvidos (investimentos, custos operacionais e de manutenção, recursos advindos da comercialização dos créditos de carbono). Foi também avaliado o impacto da introdução do sistema de refrigeração nos custos de produção do litro do leite e nos valores recebidos pelo produtor na venda do produto.

A análise mostra que a utilização de um gerador acionado por um motor de combustão interna de ciclo Otto movido a biogás é a melhor configuração para um novo sistema. Para sistemas já existentes, a substituição da compra de energia elétrica por geração in loco também é uma alternativa interessante, ainda que apresente um tempo de retorno de investimento relativamente elevado para os padrões brasileiros. 


\begin{abstract}
The Brazilian dairy sector is characterized by a great number of producers, presenting low productivity and product quality. Concerning to quality, it is necessary the implantation of cooling systems for milk and conservation on farm. However, a low milk production level and the electric power availability on rural areas sometimes make unfeasible investments on these types of coolers.

In this context, the goal of this work is to determine the best configuration of a milk cooling system for small and medium-scale dairy farms to be included in an anaerobic digestion project based on the Clean Development Mechanism of the Protocol of Kyoto. Such project is to be implemented by a company interested in commercialize the carbon credits generated.

Once the project will provide to the farmer a renewable and low-cost energy resource (the biogas resulting of the anaerobic digestion), it was considered two possible sceneries: a producer that does not count on a cooling system, and a producer that may want to replace purchased electricity by a generation system based on a biogas-fueled engine to power an already existing system for milk cooling.

The work analyzed several technical aspects connected to cooling system sizing, feasible configurations for supplying the cooling demand, evaluation of the consumption of the different energy inputs (electricity and biogas) of considered configurations.

It was evaluated the carbon credits generation, as well as the involved economical aspects (investments, operational and maintenance costs, earnings from commercialization of carbon credits). It was also evaluated the impact of introducing the cooling system on milk production costs and values received by the producer.

The analysis shows that a biogas-fueled Otto-engine electrical generator is the best configuration for a new system, and that the replacement of the electric power purchase for generation on farm is also an interesting alternative, although its payback time is relatively high for Brazilian standards.
\end{abstract}




\section{SUMÁRIO}

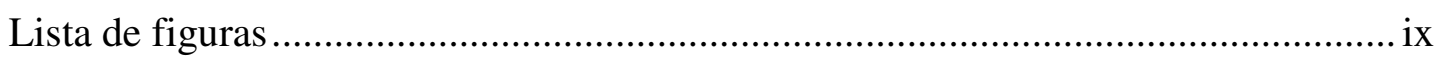

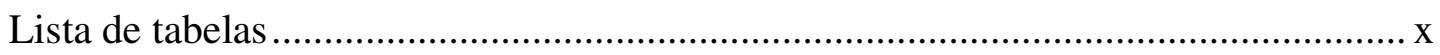

Lista de siglas e abreviaturas ....................................................................... $\mathrm{xi}$

Lista de símbolos .............................................................................................

Resumo

Abstract

1 INTRODUÇÃO E OBJETIVO ………………………………….. 1

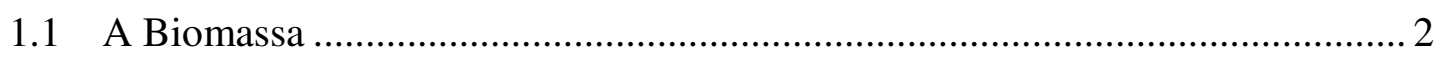

1.2 O Setor Leiteiro Brasileiro ........................................................................... 4

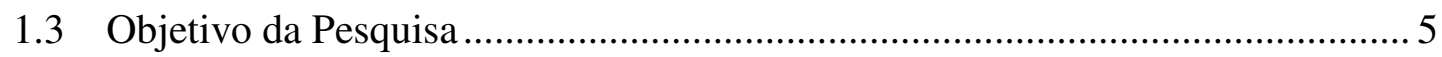

1.4 Desenvolvimento do Trabalho ……………………………………………... 6

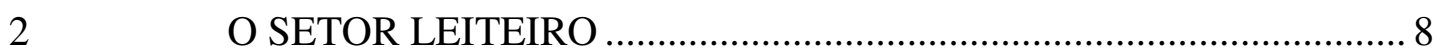

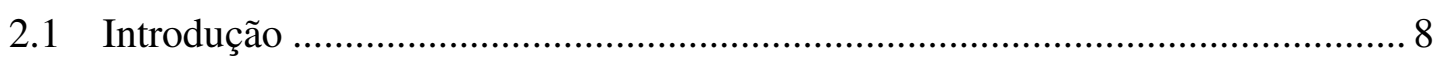

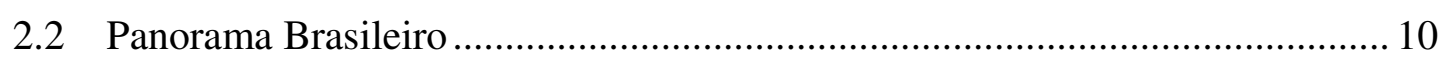

2.2.1 Competitividade da Cadeia Produtiva do Leite ……………………... 12

2.2.2 Normativa para o Gerenciamento ................................................... 13

2.2.3 Problemática do Setor .................................................................. 14

2.3 O Leite

2.3.1 Composição do Leite.......................................................................... 16

2.3.2 Propriedades do Leite........................................................................ 17

2.4 Tratamento do Leite ............................................................................. 18

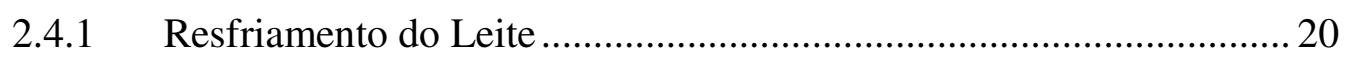

2.4.2 Retribuições econômicas................................................................. 21

3 TECNOLOGIAS DE DIGESTÃO ANAERÓBICA E PRODUÇÃO DE

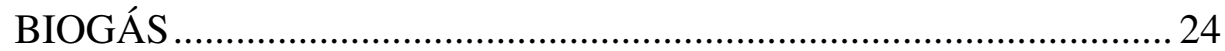

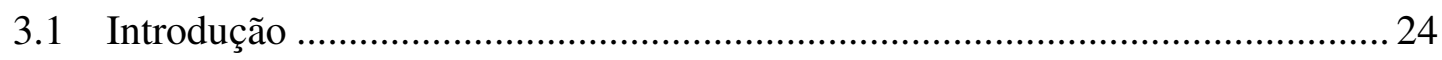

3.2 A Digestão Anaeróbica no Mundo.................................................................... 25

3.3 O Processo de Digestão Anaeróbica ………………………………………. 27

3.3.1 Fatores que Afetam a Digestão Anaeróbica...................................... 29 


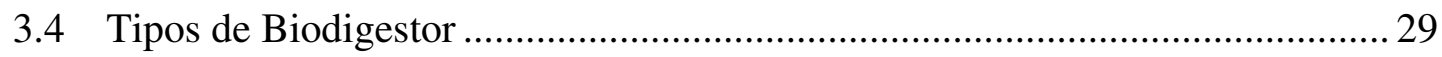

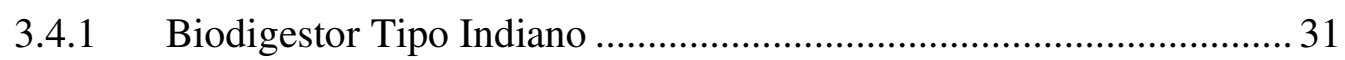

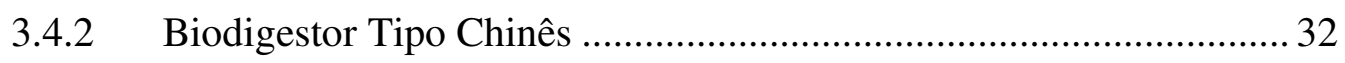

3.4.3 Biodigestor Tipo Lagoa Coberta (Covered-Lagoon) ........................ 33

3.4.4 Digestor Tipo Mistura Completa (Complete-Mix Digester) .............. 33

3.4.5 Digestor de Fluxo de Corrente (Plug-Flow Digester)....................... 34

3.4.6 Digestor de Polietileno de Baixo Custo (Low-Cost Digester) ............ 34

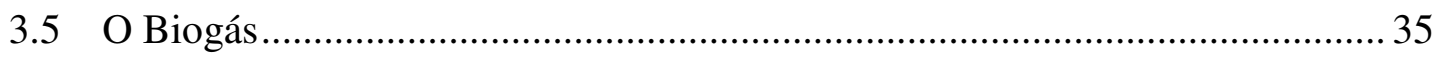

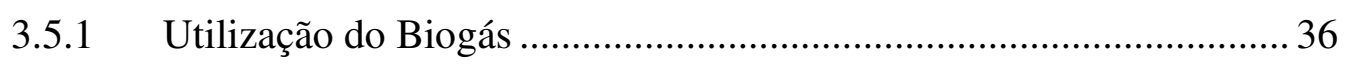

3.5.2 Tratamento do Biogás ................................................................ 37

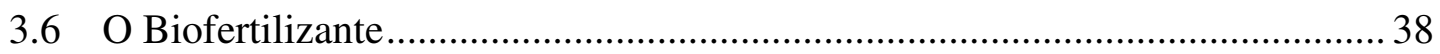

3.7 Escalas de Aproveitamento do Biogás ............................................................... 39

3.7.1 Utilização do Biogás em Pequenas Propriedades Familiares ............ 39

3.7.2 Utilização do Biogás em Médias e Grandes Propriedades................. 43

4 SISTEMAS DE GERAÇÃO DE ENERGIA E DE RESFRIAMENTO DE LEITE ............................................................................. 47

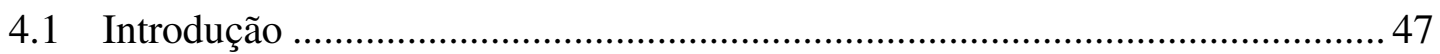

4.2 Motor de Combustão Interna (MCI) ……................................................... 48

4.2.1 Substituição Total de Gasolina por Biogás em MCI de Ciclo Otto ... 50

4.2.2 Substituição Parcial de Diesel por Biogás em MCI de Ciclo Diesel . 53

4.2.3 Manutenção de motores com substituição parcial ou total de biogás 56

4.3 Sistemas de Resfriamento de Leite ..................................................................... 56

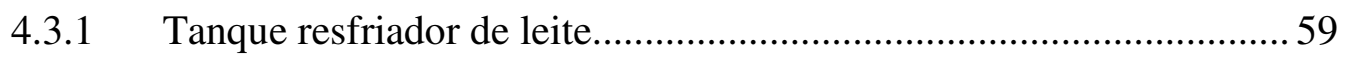

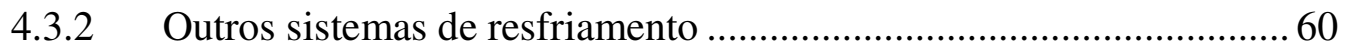

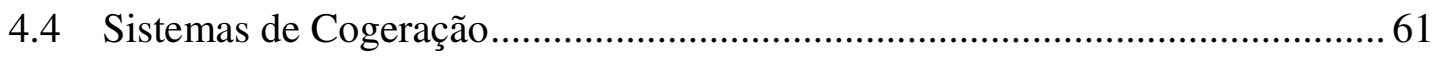

5 O EFEITO ESTUFA E O SETOR AGROPECUÁRIO.........................6 64

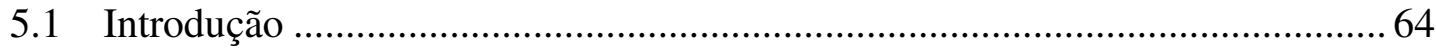

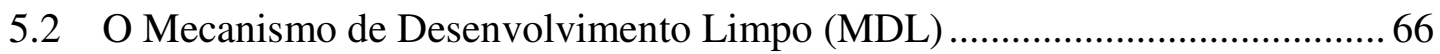

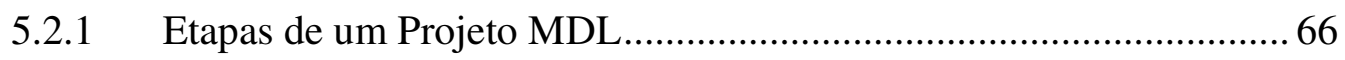

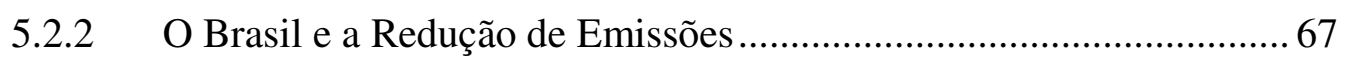

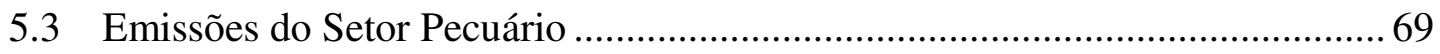

5.4 Projeto MDL para Fazendas Leiteiras............................................................. 70 
5.5 Quantificação das Emissões 72

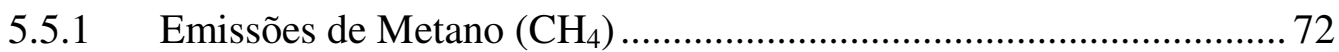

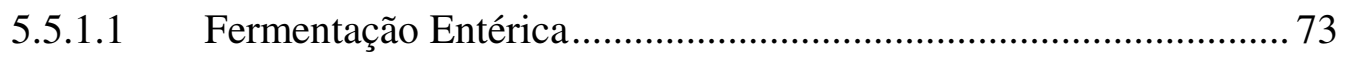

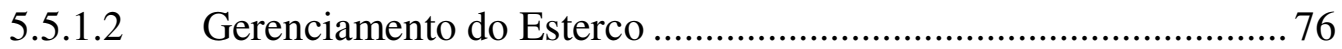

5.5.2 Emissões de Óxido Nitroso $\left(\mathrm{N}_{2} \mathrm{O}\right)$ dos SGEA ................................. 78

5.6 Redução de Emissões de GEE ...................................................................... 80

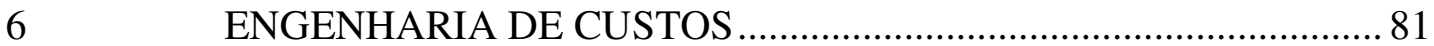

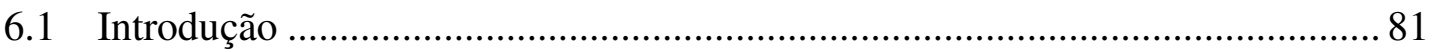

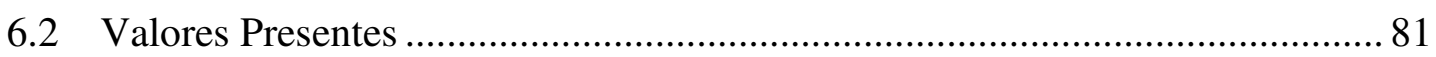

6.2.1 Valor Presente de Um Valor Futuro................................................... 81

6.2.2 Valor Presente de uma Série Uniforme de Montantes $\left(\mathrm{VP}_{\mathrm{S}}\right)$............. 82

6.3 Custo de Capital ou Investimento Total (IT) ............................................... 83

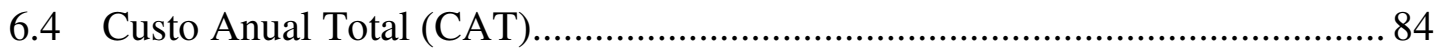

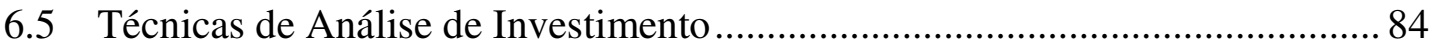

6.5.1 Método do Valor Presente Líquido (VPL) ......................................... 84

6.5.2 Método da Taxa Interna de Retorno (TIR) ...................................... 85

6.6 Comparação de Opções de Projeto em Termos de Custos................................. 86

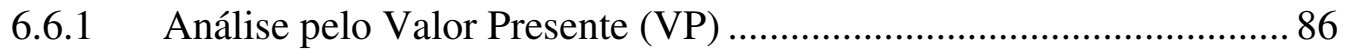

6.6.2 Análise da Economia de Ciclo de Vida (ECV) ............................... 87

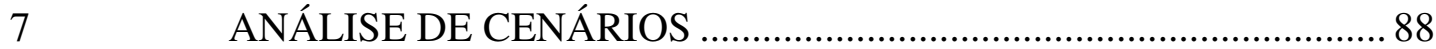

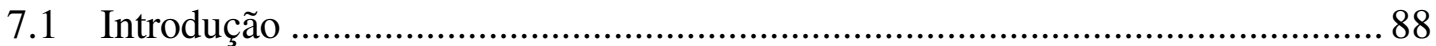

7.2 Dimensionamento do Sistema de Resfriamento de Leite ................................8 89

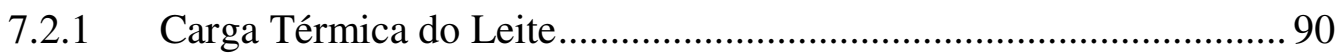

7.3 Quantificação das Emissões de GEE e dos Créditos de Carbono Gerados....... 92

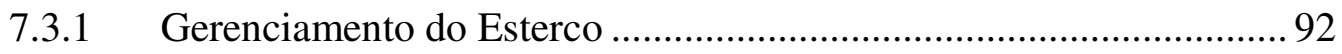

7.3.1.1 Emissões de Metano....................................................................... 93

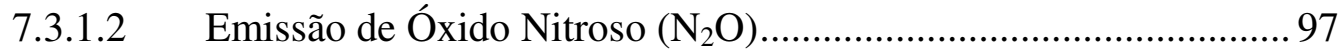

7.3.1.3 Quantificação da Emissão de GEE na Utilização do Biogás ......... 99

7.3.1.4 Emissão Total e Redução Líquida de GEE .................................. 100

7.4 Sistema de Produção de Biogás - O Biodigestor.............................................. 101

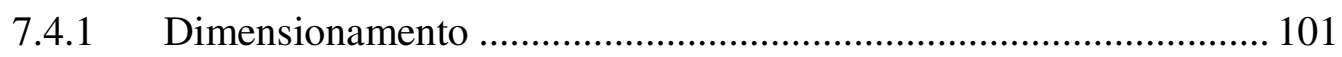

7.4.2 Uso do Biogás na Geração de Potência.............................................. 103 


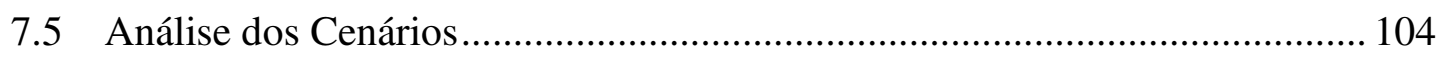

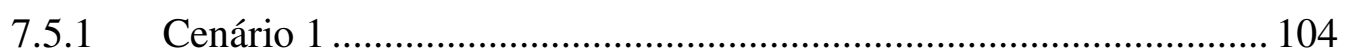

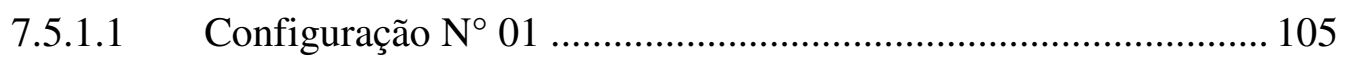

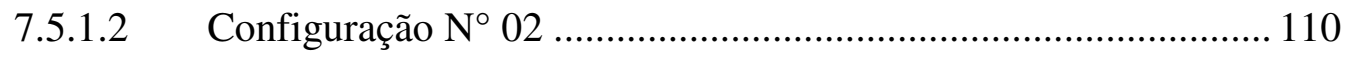

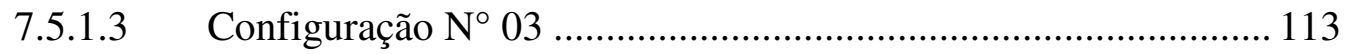

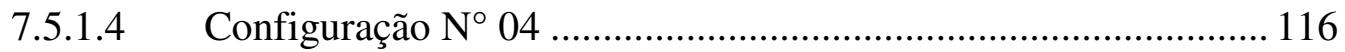

7.5.1.5 Outras Configurações Analisadas ............................................... 118

7.5.1.6 Comparação Econômica das Configurações ................................ 119

7.5.1.7 Custo de Resfriamento do Leite .................................................. 120

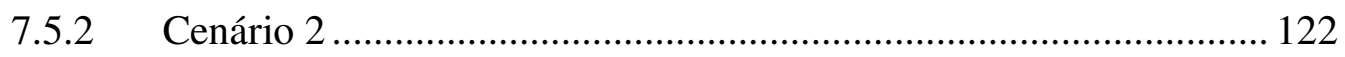

$8 \quad$ CONCLUSÕES E RECOMENDAÇÕES ......................................... 124

9 REFERÊNCIAS BIBLIOGRÁFICAS ............................................ 127

ANEXO A A INSTRUÇÃO NORMATIVA 51 .............................................. 136

ANEXO B A INSTRUÇÃO NORMATIVA 53 .............................................. 140 


\section{LISTA DE FIGURAS}

Figura 3.1. Estrutura de caixa-preta para o biodigestor....................................... 27

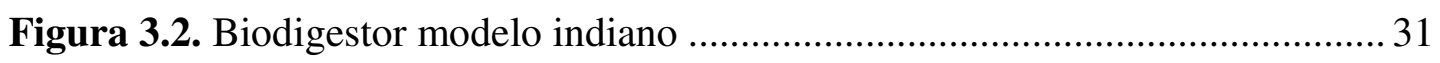

Figura 3.3. Biodigestor modelo chinês ................................................................. 32

Figura 3.4. Biodigestor de coberta hermética de PVC.............................................. 33

Figura 3.5. Biodigestor plástico de baixo custo ....................................................... 34

Figura 3.6. Integração da DA em sistemas agropecuários...................................... 40

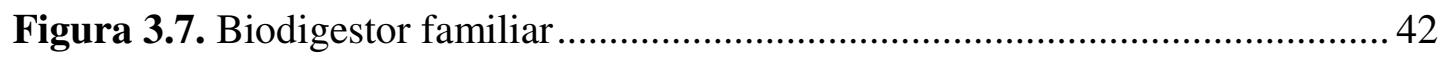

Figura 3.8. Componentes e produtos de um sistema de recuperação de biogás ....... 43

Figura 3.9. Sistema de Energia Integrado numa fazenda leiteira............................ 45

Figura 4.2. Comparação entre os ciclos por compressão de vapor e por absorção... 58

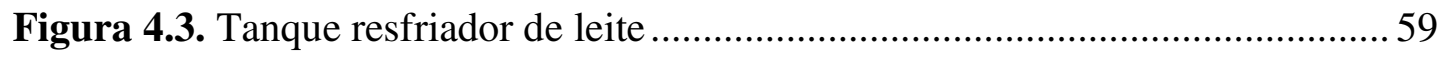

Figura 7.2. Gerenciamento do esterco por lagoa anaeróbica .................................. 95

Figura 7.3. Gerenciamento do esterco por biodigestor de lagoa coberta..................96

Figura 7.4. Unidade condensadora por compressão de vapor e tanque de

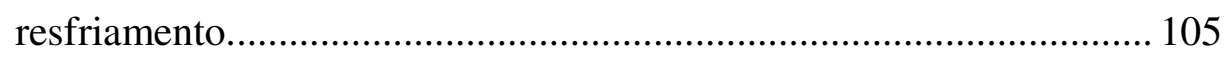

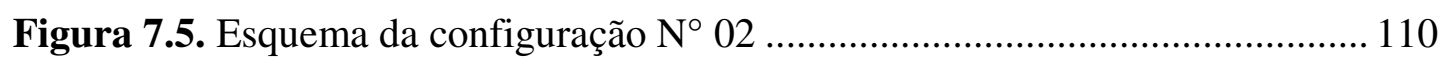




\section{LISTA DE TABELAS}

Tabela 2.1. Produção de Leite, Vacas Ordenhadas e Produtividade em Países Selecionados, 2005

Tabela 2.2. Composição quantitativa do leite de vaca

Tabela 2.3. Preço médio recebido pelos produtores de leite tipo C em julho de 2005

Tabela 2.4. Custo de produção de leite nas 5 principais bacias leiteiras do Brasil, agosto de 2000 a julho de 2001 22

Tabela 2.5. Principais características do PROLEITE 23

Tabela 3.1. Produção de biogás a partir de diferentes substratos 28

Tabela 3.2. Composição típica do biogás. 35

Tabela 3.3. Equivalência aproximada de $1,0 \mathrm{~m}^{3}$ de biogás..................................... 36

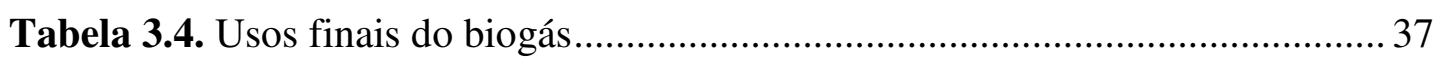

Tabela 5.1. Potencial de produção de metano e sólidos voláteis de gado leiteiro .... 77

Tabela 5.2. Fator de conversão de metano (FCM) .................................................. 78

Tabela 5.3. Taxa de excreção de nitrogênio segundo a região (kg/animal/ano) ........ 80

Tabela 5.4. Valores estimados para os fatores de emissão de $\mathrm{N}_{2} \mathrm{O}$ de diversos sistemas de gerenciamento de detritos animais $\left(\mathrm{kg}_{\mathrm{N} 2 \mathrm{O}-\mathrm{N}} / \mathrm{kg}_{\mathrm{Nex}}\right)$. 80

Tabela 7.1. Parâmetros para o cálculo da emissão de metano ................................... 93

Tabela 7.2. Ficha técnica do biodigestor selecionado........................................... 103

Tabela 7.3. Principais características do biogás considerado.................................. 103

Tabela 7.4. Tempo de operação em função da potência do MCI............................. 104

Tabela 7.5. Tanque de resfriamento de leite selecionado. ..................................... 106

Tabela 7.6. Tanque de resfriamento de leite selecionado ...................................... 107

Tabela 7.7. Tarifas médias para o setor rural. ........................................................ 110

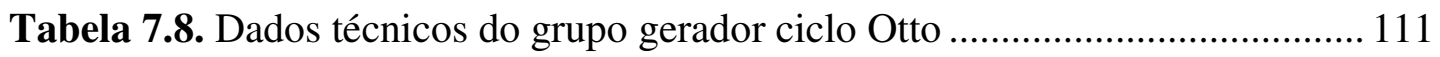

Tabela 7.9. Dados técnicos do moto-gerador a diesel.......................................... 114

Tabela 7.10. Dados técnicos do chiller de absorção ................................................ 117

Tabela 7.11. Comparação de custos para o cenário 1 ............................................. 119

Tabela 7.12. Análise de custos para o cenário 1 ................................................... 121

Tabela 7.13. Comparação de custos do cenário 2................................................. 123 


\section{LISTA DE SIGLAS E ABREVIATURAS}

\begin{tabular}{|c|c|}
\hline ANEEL: & Agência Nacional de Energia Elétrica \\
\hline BNDES: & Banco Nacional de Desenvolvimento Econômico e Social \\
\hline BIRD: & Banco Internacional de Reconstrução e Desenvolvimento \\
\hline CAL: & Cadeia Agroindustrial do Leite \\
\hline CCL: & Centro de coleta de leite \\
\hline CEPEA: & Centro de Estudos Avançados em Economia Aplicada \\
\hline CERs: & Certificados de Emissões Reduzidas \\
\hline CFC: & Cloro-Flúor-Carbono \\
\hline CIMGC: & Comissão Interministerial sobre Mudança Global do Clima \\
\hline CNPT: & Condições normais de pressão e temperatura \\
\hline CONSAGRO: & Conselho do Agronegócio \\
\hline DA: & Digestão anaeróbica \\
\hline DCP: & Documento de Concepção do Projeto MDL \\
\hline ECO-92: & $\begin{array}{l}\text { Conferência das Nações Unidas sobre o Ambiente e o } \\
\text { Desenvolvimento (segunda conferência) }\end{array}$ \\
\hline EMBRAPA: & Empresa Brasileira de Pesquisa Agropecuária \\
\hline EMBRATER: & Empresa Brasileira de Assistência Técnica e Extensão Rural \\
\hline EMATER: & Empresa de Assistência Técnica e Extensão Rural \\
\hline EOD: & Entidade Operacional Designada pela ONU \\
\hline EPA: & Agência de Proteção ao Meio Ambiente dos EUA \\
\hline EVT: & Estudo de viabilidade técnica \\
\hline FAO: & $\begin{array}{l}\text { Organização das Nações Unidas para a Agricultura e a } \\
\text { Alimentação (Food and Agriculture Organization) }\end{array}$ \\
\hline GEE: & Gases causadores do efeito estufa \\
\hline GLP: & Gás liquefeito de petróleo \\
\hline GN: & Gás natural \\
\hline GWP: & Potencial de aquecimento global (Global Warming Potential) \\
\hline IN51: & Instrução normativa 51 \\
\hline IPCC: & Painel Intergovernamental sobre Mudanças Climáticas \\
\hline MCI: & Motor de combustão interna \\
\hline MDL: & Mecanismo de Desenvolvimento Limpo \\
\hline MAPA: & Ministério da Agricultura, Pecuária e Abastecimento \\
\hline NAE: & Núcleo de Assuntos Estatísticos da Presidência da República \\
\hline ONU: & Organização das Nações Unidas \\
\hline O\&M: & Operação e manutenção \\
\hline PENSA: & Programa de Estudos dos Negócios do Setor Agroindustrial \\
\hline PNQL: & Programa Nacional da Qualidade do Leite \\
\hline PNUD: & Projeto das Nações Unidas Para o Desenvolvimento \\
\hline PROÁLCOOL: & Programa brasileiro de álcool \\
\hline PLANGÁS: & Plano nacional do gás \\
\hline PROINFA: & Programa de Incentivo às Fontes Alternativas de Energia Elétrica \\
\hline RTIQ'S: & Regulamentos Técnicos de Identidade e Qualidade \\
\hline SGC: & Centro de Gás da Suécia \\
\hline SGEA: & Sistema de gerenciamento de esterco animal \\
\hline
\end{tabular}


SRA:

TRH:

UNCED:

UNFCC:

UCCV:
Sistemas de refrigeração por absorção

Tempo de retenção hidráulica

Conferencia das Nações Unidas sobre o Meio Ambiente e Desenvolvimento

Convenção-Quadro das Nações Unidas sobre Mudança do clima Unidade de condensação por compressão de vapor 


\section{LISTA DE SÍMBOLOS}

Latinos

\begin{tabular}{|c|c|}
\hline AC: & Relação ar-combustível (kg ar/kg de combustível) \\
\hline $\mathrm{C}:$ & Custo $(\mathrm{R} \$)$ \\
\hline CAD: & Custos anuais diretos ( $\mathrm{R} \$ / \mathrm{ano})$ \\
\hline CAI: & Custos anuais indiretos (R $\$ / a n o)$ \\
\hline CAT: & Custos anuais indiretos ( $\mathrm{R} \$ / \mathrm{ano})$ \\
\hline CDT: & Custos diretos totais $(\mathrm{R} \$)$ \\
\hline CF: & $\begin{array}{l}\text { Custo de reformas dos equipamentos ao longo da vida do projeto } \\
\text { (R\$/ano, } \mathrm{R} \$ / \text { biênio) }\end{array}$ \\
\hline CIT: & Custos indiretos totais $(\mathrm{R} \$)$ \\
\hline CM1: & Custo de manutenção do tanque resfriador (R\$/ano) \\
\hline CM2: & Custo de manutenção de equipamentos ( $\mathrm{R} \$ / \mathrm{ano})$ \\
\hline CMT: & Custo de manutenção total (R $\$$ /ano) \\
\hline $\mathrm{CO}:$ & Custo de operação (R $\$$ /ano) \\
\hline COP: & Coeficiente de performance \\
\hline $\mathrm{COH}:$ & Custo de manutenção preventiva (R $\$$ /biênio) \\
\hline CRU: & Custo de unitário de resfriamento do leite $(\mathrm{R} \$ / \mathrm{l})$ \\
\hline EB: & Energia Bruta Ingerida (MJ/vaca/dia) \\
\hline EC: & Economia anual (R\$/ano) \\
\hline ECV: & Economia de ciclo de vida $(\mathrm{R} \$)$ \\
\hline ED: & Energia digestível (MJ/vaca/dia) \\
\hline EN/ED: & Coeficiente de digestibilidade (adimensional) \\
\hline ENcr/ED: & Coeficiente de digestibilidade-crescimento (adimensional) \\
\hline EM: & Energia metabolisável (MJ/vaca/dia) \\
\hline EN: & Requerimento Energético do Animal (MJ/vaca/dia) \\
\hline ET: & Emissão total de GEE (tonCO ${ }_{2}$-equiv/ano) \\
\hline FPP: & Fator de perda de potência (adimensional) \\
\hline FP: & Fator de produção $\left(\mathrm{kg} / \mathrm{m}^{3}\right)$ \\
\hline FC: & Fator de consumo de combustível $\left(\mathrm{m}^{3} / \mathrm{kWh}\right)$ \\
\hline FCM: & Fator de conversão de metano (\%) \\
\hline $\mathrm{FA}_{\mathrm{ar}}:$ & Fator de admissão de $\operatorname{ar}\left(\mathrm{m}^{3} / \mathrm{kWh}\right)$ \\
\hline FA: & Fator determinado pelo tipo de criação do animal (adimensional) \\
\hline FE: & Fator de emissão (kg/vaca) \\
\hline GWP: & Potencial de aquecimento global $\left(\mathrm{kg}_{\mathrm{CO} 2 \text {-equiv }} / \mathrm{kg}_{\mathrm{GEE}}\right)$ \\
\hline i: & Taxa de juros $(\%)$ \\
\hline IT: & Investimento total $(\mathrm{R} \$)$ \\
\hline $\mathrm{m}:$ & Massa (kg) \\
\hline $\mathrm{m}:$ & Vazão mássica de um fluido $(\mathrm{kg} / \mathrm{h}, \mathrm{kg} / \mathrm{s})$ \\
\hline Nex: & Excreção de nitrogênio (kg/animal/ano) \\
\hline $\mathrm{n}:$ & Anos de vida do projeto (anos) \\
\hline $\mathrm{P} / \mathrm{F}:$ & Fator de valor presente (adimensional) \\
\hline $\mathrm{P} / \mathrm{S}:$ & Fator de valor presente de séries (adimensional) \\
\hline PCI: & Poder calorífico inferior $\left(\mathrm{kJ} / \mathrm{m}^{3}\right.$ ou $\left.\mathrm{kJ} / \mathrm{kg}\right)$ \\
\hline
\end{tabular}


RE:

rpm:

SV:

SGEA:

S:

t:

$\mathrm{T}$ :

TCM:

TG:

TIR:

TRH:

TRI:

VP, P:

VPs:

VF, F:

VAL, VPL:

VR:

W:

Q:

$\mathrm{V}$ :

\section{Gregos}

$\eta:$

$\lambda$ :

$\Phi:$

\section{Subscritos}

$\begin{array}{ll}\text { ab: } & \text { absorvedor } \\ \text { agit: } & \text { Agitador } \\ \text { al: } & \text { Alimentação } \\ \text { b: } & \text { bomba } \\ \text { cd: } & \text { condensador } \\ \text { comb: } & \text { Combustão } \\ \text { comp: } & \text { Compressor } \\ \text { conserv: } & \text { Conservação } \\ \text { cr: } & \text { Crescimento } \\ \text { CR: } & \text { Configuração de referência } \\ \text { ef: } & \text { Efetiva } \\ \text { el: } & \text { Elétrica } \\ \text { ev: } & \text { evaporador } \\ \text { fe: } & \text { Fermentação entérica } \\ \text { g: } & \text { Relativo a ganho } \\ \text { ge: } & \text { gerador } \\ \text { l: } & \text { Lactação }\end{array}$

Rotações por minuto
Redução de emissões de GEE (ton CO2-equiv)

Sólidos voláteis ( $\mathrm{kg} / \mathrm{vaca}$.dia)

Sistema de gerenciamento de esterco animal

Série de valores

Tempo (h)

Temperatura $\left({ }^{\circ} \mathrm{C}\right)$

Taxa de conversão de metano (\%)

Teor de gordura $(\%)$

Taxa interna de retorno (\%)

Tempo de Retenção Hidráulica (dias)

Tempo de retorno do investimento (meses ou anos)

Valor presente $(\mathrm{R} \$)$

Valor presente de uma série $(\mathrm{R} \$)$

Valor futuro $(\mathrm{R} \$)$

Valor atual (presente) líquido ( $\mathrm{R} \$$ )

Valor de venda do equipamento no final da vida do projeto $(\mathrm{R} \$)$

Potência $(\mathrm{kW})$

Calor transferido $(\mathrm{kW})$

Vazão volumétrica de um fluido $\left(\mathrm{m}^{3} / \mathrm{h}, \mathrm{m}^{3} / \mathrm{s}\right)$

Eficiência energética (\%)

Taxa de excesso de ar

Razão de equivalência 
L: $\quad$ Leite

estq: $\quad$ Estequiométrica

m: Metabolismo

pr: $\quad$ prenhez

PR: $\quad$ Projeto (configuração alternativa)

queima: $\quad$ Combustão de insumo energético

resf: Resfriamento

vent: Ventilador 


\section{INTRODUÇÃO E OBJETIVO}

No decorrer do século XX, a demanda global de energia cresceu significativamente, e os combustíveis fósseis, principal fonte de energia, aumentaram sua participação na matriz energética mundial. É importante destacar que esse crescimento ocorreu principalmente nos países industrializados, que contam com $32 \%$ da população mundial e consomem $82 \%$ da energia produzida. $\mathrm{O}$ consumo de energia per capita, nesses países é, em média, 20 vezes maior que na África. (AN et $a l, 1997)$.

A crescente utilização de recursos energéticos não renováveis, somada ao crescimento acelerado da população mundial (de 2,5 bilhões em 1950 para cerca de 6 bilhões em 2006) e a questões geopolíticas entre produtores, desencadearam as crises do petróleo de 1973-1974 e 1979, por conta dos aumentos explosivos no custo do barril de petróleo.

Essas crises, porém, criaram uma consciência mundial da necessidade de otimizar processos e reduzir a dependência do petróleo e seus derivados, substituindo-os por fontes alternativas, preferencialmente renováveis. Assim, as questões ambientais têm contribuído no planejamento para a redução das emissões poluentes próprias, na sua maioria, da queima de combustíveis fósseis. Dessa forma, o desenvolvimento e uso de fontes de energia renováveis têm se tornado ambientalmente e até economicamente atraentes, além de serem utilizadas como marketing por diversas empresas com preocupações ecológicas.

Dentre as diversas fontes de energias renováveis, o aproveitamento da energia solar, eólica e de biomassa destacam-se como as mais promissoras. E, portanto, maiores esforços devem ser empregados a fim de consolidar sua viabilidade técnicoeconômica. Essas três fontes sempre foram aproveitadas para auxiliar as atividades 
humanas como a agricultura, o processamento de alimentos, a cocção e o conforto, entre outros. Porém, com a Revolução Industrial, em função da crescente demanda de energia, essas fontes foram sendo substituídas por outras fontes energéticas à época abundantes e de baixo custo, como o carvão mineral, o petróleo e seus derivados.

Como mencionado anteriormente, devido às crises do petróleo, as fontes renováveis estão sendo reabilitadas. Por exemplo, a Comunidade Européia, consciente do decréscimo gradual da oferta de derivados do petróleo e da importância de sua substituição por combustíveis sustentáveis, para garantir o atendimento de sua demanda, implantou um programa de substituição de recursos fósseis que prevê que a participação de bio-combustíveis na matriz energética seja de $5,75 \%$ ao final do ano de 2010 (JONSSON, 2004).

Países em desenvolvimento, como a China e a Índia, criaram programas para disseminação da tecnologia da digestão anaeróbica para diversificar a matriz energética e melhorar as condições de vida em áreas rurais, onde a disponibilidade de energia elétrica e/ou combustíveis comerciais é limitada ou muitas vezes inexistente. Já em países industrializados, principalmente da Europa, foram as motivações ambientalistas que incentivaram a difusão dessa tecnologia.

O Brasil, por sua vez, mediante a implantação de programas, como o PROÁlCOOL e o PLANGÁS, introduziu e aumentou a participação do álcool combustível e do gás natural na matriz energética nacional para diminuir a dependência dos derivados do petróleo, e com isso também diminuir tanto os gastos de importação quanto a emissão de poluentes. Mais tarde, o PROINFA foi criado com o intuito de produzir energia elétrica a partir de fontes renováveis de energia para diminuir a dependência pela hidroeletricidade (MME, 2005).

\subsection{A Biomassa}

A biomassa foi a principal fonte de energia até o início do século XX. Nos últimos anos, principalmente a partir da década de 1990, as diversas legislações 
ambientais impulsionaram a retomada das pesquisas tecnológicas sobre sistemas de conversão que aproveitam esse recurso. No entanto, o principal empecilho a uma maior utilização é sua baixa densidade energética em comparação com os combustíveis fósseis. Por consequiência, o estudo de processos termoquímicos (combustão direta e gaseificação) e biológicos (digestão anaeróbica) está permitindo o desenvolvimento de equipamentos capazes de melhorar o potencial energético dessa fonte e consolidar seu aproveitamento.

As maiores fontes de biomassa se encontram nas áreas rurais e agroindustriais, onde a quantidade de resíduos orgânicos é significativa e pode justificar a implantação de sistemas para seu aproveitamento energético. Para tanto, os tipos de recursos disponíveis (restos de culturas, esterco animal, madeira de reflorestamento para uso energético, efluentes agroindustriais) devem ser definidos, pois a viabilidade do projeto e a tecnologia de conversão de energia dependem diretamente desses recursos. Seus eventuais aproveitamentos em pequenas escalas podem permitir a criação de centrais de suprimento descentralizadas para produzir energia elétrica para consumo in loco por sistemas isolados e/ou para integração à rede pública.

No setor agropecuário, as fazendas leiteiras apresentam algumas particularidades que as tornam interessantes para a implantação de sistemas energéticos de pequena escala. Por um lado existe uma grande quantidade de detritos orgânicos (principalmente o esterco produzido pelos animais), para os quais é necessário dar-se um destino adequado, e, por outro, uma grande demanda de energia para o manejo, tratamento e conservação do leite, principalmente em fazendas mais afastadas dos centros de coleta.

O esterco bovino é uma boa matéria-prima para a produção de biogás (basicamente uma mistura de metano e dióxido de carbono) a partir de processos de digestão anaeróbica. O biogás pode ser utilizado como uma fonte de energia renovável e de menor impacto ambiental em lugar de combustíveis tradicionalmente utilizados em locais afastados das redes de transmissão de energia elétrica, como a lenha, o querosene e o óleo diesel. Além disso, o biogás pode ser utilizado no 
acionamento de grupos geradores baseados em motores de combustão interna para substituir a energia elétrica comprada da rede de distribuição.

\subsection{O Setor Leiteiro Brasileiro}

O setor leiteiro brasileiro tem como característica o grande número de produtores, que, porém, apresentam baixos índices de produtividade e qualidade. Isso representa um empecilho a esses produtores na hora de competir, no mercado local, com produtos vindos de outros mercados interligados, como, por exemplo, o Mercosul. Representa também uma dificuldade para aumentar a capacidade exportadora do país, em virtude das crescentes exigências sanitárias e de qualidade dos mercados internacionais.

Esse quadro caracteriza a necessidade de mudanças estruturais para reverter essa situação e permitir que os produtores locais atinjam níveis de competitividade para um adequado atendimento do mercado interno e a exportação de excedentes, como é o caso de outros países.

Portanto, existe um longo caminho a ser percorrido pela pecuária leiteira nacional, caminho esse que passa pela profissionalização de toda a cadeia, que apresenta grandes diferenças tecnológicas e gerenciais nos seus diversos níveis. Assim, são necessários investimentos para a implantação de tecnologia dentro das atividades de produção de leite, tais como a refrigeração e a ordenha mecânica, entre outras, que muitas vezes são inviabilizados por conta dos baixos volumes de produção, principalmente de pecuaristas não especializados.

Particularmente para a refrigeração, os dois principais entraves para uma maior utilização de tecnologias, além dos aspectos culturais, são o acesso a formas de financiamento e a disponibilidade de energia elétrica. Uma alternativa que se coloca para vencer essas dificuldades é a implantação, no âmbito do Mecanismo de Desenvolvimento Limpo (MDL) do Protocolo de Kyoto, de projetos de instalação de biodigestores para o gerenciamento adequado dos detritos animais visando à redução das emissões de gases causadores do efeito estufa (GEE). 
Esses biodigestores possibilitam a geração de recursos econômicos, pela comercialização dos créditos de carbono, e de um insumo energético renovável (o biogás) de baixo custo. Além do biogás, o efluente resultante da digestão anaeróbica pode ser utilizado (e conseqüentemente comercializado) como substituto de fertilizantes químicos. Isso poderia auxiliar na viabilização econômica da implantação de sistemas de resfriamento para atender as crescentes exigências de qualidade do leite.

\subsection{Objetivo da Pesquisa}

Este trabalho considera dois aspectos complementares ao desenvolvimento sustentável de atividades leiteiras. São avaliadas situações/configurações técnica e economicamente adequadas para o resfriamento de leite, e por outro lado é quantificado o potencial de redução de emissões de gases de efeito estufa decorrente da inclusão da fazenda leiteira em projetos MDL de instalação de biodigestores para o gerenciamento adequado dos detritos animais.

Assim, o objetivo deste trabalho é determinar qual a melhor configuração para o sistema de resfriamento de leite de uma fazenda leiteira de pequeno ou médio porte, que será inserida em um projeto MDL implementado por uma empresa interessada na comercialização dos créditos de carbono. Essa determinação tem como critério a configuração que apresente o menor custo final para o produtor, e considera dois possíveis cenários:

- o de um produtor que ainda não conta com um sistema para resfriamento de leite in loco;

- o de um produtor que já conta com um sistema de resfriamento de leite acionado por energia elétrica e estuda a viabilidade de investir em um sistema de geração de energia para aproveitar o biogás gerado no processo de digestão anaeróbica dos detritos animais na substituição dessa energia elétrica adquirida da rede pública de distribuição. 
Serão analisados os aspectos técnicos ligados ao dimensionamento das configurações, avaliação do consumo dos diferentes insumos energéticos (eletricidade e biogás) e quantificação dos créditos de carbono, bem como os aspectos econômicos envolvidos (investimentos, custos operacionais e de manutenção, recursos advindos da comercialização dos créditos de carbono). Será também avaliado o impacto da introdução do sistema de refrigeração nos custos de produção do litro do leite e nos valores recebidos pelo produtor na venda do produto.

Adicionalmente, será demonstrado que os produtores leiteiros não especializados, mediante a implantação dessa tecnologia, podem melhorar sua atividade produtiva, reduzindo o risco de perda de produto por proliferação de agentes patogênicos e produzindo um leite de melhor qualidade, atendendo assim às crescentes exigências sanitárias e garantindo sua permanência no mercado. Conseqüentemente, as despesas podem ser reduzidas e eventualmente a receita incrementada por meio da venda de excedentes de energia.

\subsection{Desenvolvimento do Trabalho}

O capítulo 2 apresenta uma panorâmica do setor leiteiro brasileiro, seus problemas e as regulamentações sanitárias vigentes. Apresenta, também, uma descrição das principais características e propriedades do leite e a questão de seu tratamento e resfriamento.

No capítulo 3, são abordados os diversos aspectos tecnológicos ligados à digestão anaeróbica e utilização do biogás como insumo energético. A seguir, o capítulo 4 discute os equipamentos para geração de energia e sistemas de resfriamento que podem ser utilizados em fazendas leiteiras.

O capítulo 5 introduz a questão do controle das emissões de gases causadores do efeito estufa (GEE), o Protocolo de Kyoto e o Mecanismo de Desenvolvimento Limpo (MDL). A seguir é descrita a metodologia para quantificação das emissões de carbono em fazendas leiteiras. Já o capítulo 6 apresenta o equacionamento utilizado para a análise econômica. 
O capítulo 7 desenvolve a análise técnico-econômica para as diferentes configurações de sistemas de resfriamento de leite. O capítulo se inicia com a avaliação da demanda de carga térmica a ser atendida pelo sistema de refrigeração, a quantificação dos créditos de carbono gerados pela substituição de uma lagoa anaeróbica (manejo convencional) pelo biodigestor, indicando o volume total de recursos gerados pela venda desses créditos a preços atuais de mercado e a parcela desses recursos que cabe ao fazendeiro.

A seguir são analisados tecnicamente os cenários já destacados anteriormente. É apresentado o dimensionamento das configurações consideradas e a avaliação dos consumos energéticos anuais. Por fim, são avaliados os custos totais (investimentos, operação e manutenção) em termos de valores presentes (VP) e da economia do ciclo de vida (ECS), a partir dos quais se indicam as configurações economicamente mais atraentes para o produtor.

Concluindo o trabalho, o capítulo 8 apresenta recomendações para trabalhos futuros, destacando-se estender o presente estudo para atender a todas as demandas energéticas da fazenda leiteira, e não apenas a do sistema de resfriamento de leite, bem como a possibilidade de se utilizar sistemas de cogeração para produção de água quente, outra demanda comum em fazendas leiteiras. 


\section{O SETOR LEITEIRO}

\subsection{Introdução}

O setor agropecuário se destaca como um importante fixador de mão-de-obra no campo e gerador de renda. Além da sua importância nutritiva, o leite desempenha um relevante papel social em países em desenvolvimento como o Brasil, principalmente na geração de empregos, pois é produzido principalmente em pequenas propriedades rurais, em que a mão-de-obra familiar é empregada. Em 2003, no país eram mais de um milhão e cem mil propriedades que exploravam leite, ocupando diretamente 3,6 milhões de pessoas (CARVALHO et al., 2003).

Vilela (2002) estima que para cada $\mathrm{R} \$ 1,00^{1}$ investido na produção do Sistema Agroindustrial (SAG) do leite, registra-se um crescimento de $\mathrm{R} \$ 5,00$ no produto interno bruto (PIB) do país, o que coloca esse setor à frente de outros tão importantes como a siderúrgica e a indústria têxtil.

O desenvolvimento da indústria leiteira nos diferentes países é influenciado por fatores como a relativa importância de sua população urbana e rural, a experiência da indústria leiteira e sua adaptação aos avanços tecnológicos, e a educação dos consumidores com respeito ao consumo do leite e seus derivados.

O aprimoramento desses fatores tem levado certos países a se tornarem os principais produtores de leite no mundo (Tab. 2.1). Dentre esses, os, altos índices de produtividade alcançados pelos Estados Unidos o tornaram líder absoluto em produção de leite, e hoje esse país responde por $15 \%$ da produção mundial.

\footnotetext{
${ }^{1}$ Cotação aproximada do dólar americano (agosto de 2006): US\$ 1,00 = R \$ 2,15
} 
Tabela 2.1. Produção de Leite, Vacas Ordenhadas e Produtividade em Países Selecionados, 2005.

\begin{tabular}{cccc}
\hline País & $\begin{array}{c}\text { Produção anual de leite } \\
\text { (milhões de litros ) }\end{array}$ & $\begin{array}{c}\text { Vacas } \\
\text { ordenhadas } \\
\text { (mil cabeças) }\end{array}$ & $\begin{array}{c}\text { Produtividade } \\
\text { (litros/vaca/ano) }\end{array}$ \\
\hline Estados Unidos & 80.150 & 9.025 & 8.881 \\
Índia & 38.500 & 38.500 & 1.000 \\
Federação Russa & 30.600 & 9.792 & 3.125 \\
Alemanha & 27.600 & 4.286 & 6.440 \\
França & 25.282 & 3.861 & 6.548 \\
Brasil & 25.000 & 20.500 & 1.220 \\
China & 24.530 & 8.632 & 2.842 \\
Nova Zelândia & 14.625 & 3.977 & 3.677 \\
Reino Unido & 14.577 & 2.090 & 6.975 \\
Ucrânia & 14.000 & 4.395 & 3.185 \\
Polônia & 12.400 & 2.730 & 4.542 \\
Países Baixos & 10.532 & 1.471 & 7.160 \\
Itália & 10.500 & 1.913 & 5.489 \\
Austrália & 10.150 & 2.040 & 4.975 \\
México & 9.874 & 6.870 & 1.437 \\
Canadá & 8.100 & 1.066 & 7.598 \\
Argentina & 8.100 & 2.000 & 4.050 \\
Chile & 2.365 & 1.765 & 1.340 \\
Outros países & 162.948 & 114.267 & 1.426 \\
\hline TOTAL & 529.833 & 239.180 & 2.215 \\
\hline & & &
\end{tabular}

Fonte: EMBRAPA (2006a)

A existência de muitos produtores com baixa produtividade e qualidade do leite (Tab. 2.1), caracteriza a necessidade de mudanças estruturais que permitam, a qualquer país, alcançar um nível de competitividade em que o mercado interno seja atendido e os excedentes exportados.

Essas mudanças passam pela profissionalização de toda a cadeia, particularmente em países como o Brasil, que apresenta grandes diferenças 
tecnológicas e gerenciais nos seus diversos níveis. As profundas mudanças aplicadas ao Sistema Agroindustrial do leite brasileiro desde 1991 permitiram registrar, no período entre 1991 e 2000, um crescimento acumulado de aproximadamente $40 \%$ na produção de leite, tornando-o no $6^{\circ}$ produtor mundial de leite (posição que disputa com a China).

Anos de experiência mostraram aos principais produtores leiteiros do mundo que a especialização na produção de leite, por meio do melhoramento genético e alimentar do rebanho e a inserção de tecnologia para o tratamento do leite, entre outros, possibilita aumentar a produtividade, rentabilidade e competitividade do negócio.

Além disso, o cooperativismo é indicado como o melhor sistema econômico para os produtores pecuários se defenderem de uma estrutura de mercado desequilibrada, onde existem muitos vendedores fracos para poucos compradores fortes. Por exemplo, nos Estados Unidos $70 \%$ do leite passa pelas cooperativas. $\mathrm{Na}$ Nova Zelândia uma cooperativa controla toda a exportação de lácteos. Na Holanda toda a inseminação do gado leiteiro é feita por uma cooperativa (LEITE BRASIL, 2001).

No Brasil, o cooperativismo teve uma fase empolgante que se caracterizou pela formação de centenas de cooperativas regionais e sete grandes centrais. O sistema chegou a controlar $80 \%$ do leite produzido no país, com o conseqüente domínio do mercado varejista das grandes capitais. Essa fase estendeu-se até início dos anos 90, quando o cooperativismo entrou em profunda crise. Muitas das centrais e dezenas de cooperativas regionais fecharam ou foram vendidas para multinacionais. No começo do século XXI, o leite oriundo do cooperativismo representava menos de $50 \%$ da produção nacional (LEITE BRASIL, 2001).

\subsection{Panorama Brasileiro}

A década de 1990 foi palco de diversas e importantes transformações na cadeia de produção de leite no Brasil. Nesse período registrou-se um crescimento médio de 
cerca de $4 \%$ ao ano, porém acompanhado de uma gradativa redução dos preços pagos ao produtor pelo litro de leite, o que poderia configurar um certo contra-senso visto que, em um mercado competitivo, quando há redução dos preços ocorre um desestímulo ao aumento da produção (SHIAVI, 2005).

Dentre as mudanças mais importantes destacam-se o fim do tabelamento de preços do leite pago ao produtor, controlado pelo governo por mais de 50 anos, a redução significativa da sazonalidade de produção (período de entressafra), a abertura de novas fronteiras de produção de leite (como exemplo o caso de Goiás que passou a ser o segundo maior estado produtor de leite), e a melhoria da produtividade dos rebanhos e redução do número de cabeças.

Já nos últimos anos, dificuldades organizacionais como a importação de produtos lácteos subsidiados na origem e o aumento da informalidade do setor, têm entravado os esforços para aperfeiçoar o setor leiteiro; por outro lado, a estabilização econômica, trouxe um aumento na demanda por produtos lácteos, como o iogurte e bebidas lácteas.

Entre todos os fatos marcantes que envolveram a Cadeia Agroindustrial do Leite (CAL), a gradativa e crescente preocupação com a melhoria da qualidade do leite se destaca como um dos principais. Atualmente, a demanda de produtos lácteos com maiores prazos de validade e manutenção de suas características organolépticas, nutritivas e de segurança são requisitos cada vez mais importantes para o consumidor, para a indústria e, conseqüentemente, para o produtor.

Em função de todos esses aspectos, em setembro de 2002 foi editada pelo Ministério da Agricultura, Pecuária e Abastecimento a Instrução Normativa $n^{\circ} .51$ (IN51), visando modernizar a antiga legislação vigente, datada em 1952, para o novo cenário brasileiro e mundial. Dentre os aspectos mais significativos destaca-se a qualidade microbiológica do leite, que se tornou mais rígida, o resfriamento do leite na fazenda e a coleta a granel (SANT'ANNA et al., 2003).

Esses dois últimos aspectos, ambos estimulados pelas indústrias coletoras de leite, foram as medidas que, isoladamente, trouxeram maior e mais rápido impacto 
sobre a melhoria da qualidade do leite. Cabe ressaltar que é impossível melhorar a qualidade do leite depois que ele deixa o local de produção. Portanto, a fazenda deve ser vista como o ponto de partida na implementação de exigências sanitárias mais restritas.

\subsubsection{Competitividade da Cadeia Produtiva do Leite}

Com a finalidade de aumentar a competitividade da cadeia produtiva do leite no país, foi criada a Câmara Setorial da Cadeia Produtiva do Leite e Derivados, no âmbito do Conselho do Agronegócio (CONSAGRO) do Ministério da Agricultura, Pecuária e Abastecimento (MAPA), da qual participam representantes dos produtores, da indústria, do varejo e do governo.

Segundo Martins (2004), algumas medidas estão sendo discutidas à procura de soluções para os problemas da cadeia do leite e são relevantes para dar maior transparência e equidade na cadeia produtiva do leite no Brasil. Dentre essas:

- fortalecimento do associativismo;

- treinamento e capacitação de produtores e trabalhadores rurais;

- contratos de fornecimento/preços antecipados aos produtores;

- linhas de crédito;

- intensificar o programa de melhoria da qualidade do leite;

- implementação de programas institucionais;

- consolidação do Brasil no mercado internacional de lácteos.

Dentro das ações que tanto o setor privado como o governo deve aprimorar no intuito de promover o aumento da competitividade da Cadeia Produtiva do Leite no mercado internacional, podem ser destacadas as seguintes:

- promover as exportações de leite e derivados;

- estimular o consumo mediante o marketing para o fortalecimento do setor; 
- desonerar os produtos lácteos na reforma tributária.

O Brasil tem chances reais de ser uma grande plataforma exportadora de lácteos. Não apenas porque produz leite a custo imbatível, trunfo decisivo num mercado altamente competitivo, mas também porque as condições naturais do país fazem com que a produção nacional seja elástica, podendo ser aumentada de acordo com as necessidades.

\subsubsection{Normativa para o Gerenciamento}

O Programa Nacional de Melhoria da Qualidade do Leite (PNQL) foi implementado em 1996 pelo Ministério de Agricultura, Pecuária e Abastecimento (MAPA) com o objetivo de elaborar, diagnosticar e formular estratégias para a melhoria da qualidade do leite produzido no Brasil. Fruto desse programa, em 2002 foi publicada a Instrução Normativa $\mathrm{n}^{\circ}$. 51 (IN51), com novas normas de produção leiteira, visando o aumento da competitividade e a modernização do setor leiteiro no Brasil (NERO et al., 2005).

A IN51 apresenta Regulamentos Técnicos de Identidade e Qualidade (RTIQ’s) de leite tipo A, B, C, leite cru refrigerado, leite pasteurizado, bem como a refrigeração do leite na propriedade rural e o seu transporte a granel. Portanto regulamenta a conservação, coleta e transporte de leite cru refrigerado.No caso de pequenos produtores, é prevista a possibilidade de aquisição de tanques resfriadores comunitários, para evitar sua exclusão por não contarem com recursos financeiros para adquirir equipamentos de refrigeração.

A coleta a granel do leite resfriado é efetuada por caminhões-tanque, que o encaminha aos laticínios para processamento. Na recepção dos laticínios, esse leite não deverá apresentar temperaturas superiores a 4 e $7^{\circ} \mathrm{C}$ para os leites tipo $\mathrm{B}$ e $\mathrm{C}$, respectivamente (NERO et al., 2005). Por outro lado, é permitido o transporte de leite em latões à temperatura ambiente, desde que se atendam os padrões fixados de qualidade. Onde a planta processadora concorde em trabalhar com esse tipo de matéria-prima, essa deverá ser entregue em no máximo até 2 horas após a ordenha. 
O anexo A apresenta, com maior nível de detalhamento, as diversas disposições da Instrução Normativa $n^{\circ} .51$

\subsubsection{Problemática do Setor}

Apesar dos enormes e inegáveis benefícios oriundos do resfriamento do leite na fazenda e granelização do transporte, uma série de fatores limitantes merecem ser mencionados e ponderados, como é o caso da eletrificação rural ${ }^{2}$, a estrutura viária, o custo dos equipamentos e o treinamento dos produtores. Esses fatores podem levar à marginalização/exclusão dos produtores.

No Brasil é possível classificar inúmeros tipos de produtores de leite, porém costuma-se classificar por produtores especializados e não-especializados. Para os primeiros, a produção de leite representa sua principal atividade, obtida a partir de rebanhos leiteiros especializados onde a genética e a alimentação são aprimoradas e a tecnologia é inserida para auxiliar na produção de leite de qualidade.

Já para os produtores não-especializados, chamados de "extratores", o leite ainda é um subproduto da pecuária de corte (ou vice-versa, dependendo da época do ano). Eles encontram no leite uma atividade típica de subsistência, portanto nãoempresarial, que serve mais como uma fonte adicional de liquidez mensal. São eles os principais responsáveis pela formação de excedentes de leite de baixa qualidade, devido à ausência de sistemas de refrigeração (PENSA, 1998).

A refrigeração e a coleta a granel do leite (granelização) representam a médio prazo um forte impacto sobre o produtor não-especializado de leite. Isto porque a granelização força a homogeneização do leite na linha de coleta. Dessa forma, os produtores que não se adaptarem à nova regra deverão obrigatoriamente deixar de

\footnotetext{
${ }^{2}$ Em muitas regiões o custo da extensão de redes de transmissão/distribuição é considerado alto, em função de diversos fatores: grandes distâncias, vegetação, rios, etc., de forma que normalmente não é economicamente viável, pois o consumo esperado de energia nessas regiões é muito baixo.
} 
entregar o produto, sob pena de prejudicar os demais. Dessa forma os produtores são excluídos do mercado ou simplesmente entram na informalidade.

No entanto, um resfriador de leite, mesmo em pequenas dimensões, representa um investimento significativo para uma pequena unidade de produção. Algumas estatísticas apontam como média nacional uma produção de 47 litros de leite por dia, um volume considerado insuficiente para custear um tanque de resfriamento (PENSA, 1998).

Por outro lado, a simples instalação de um tanque de resfriamento na fazenda não é a solução imediata para todos os males da qualidade do leite. É fundamental que o produtor saiba operar corretamente o novo equipamento, fator extremamente importante em um programa de disseminação de resfriamento de leite (GONÇALVES, 2006).

Problemas técnicos ou no fornecimento de energia determinam, na maioria das vezes, a perda completa da produção ou o comprometimento de todo o leite de um caminhão-tanque. A implantação de um sistema de resfriamento de leite e coleta a granel exige um cuidadoso estudo por parte das indústrias, produtores e transportadores de leite.

Contudo, é importante salientar que, a curto e médio prazo, os produtores médios e médios-grandes são, no geral, aqueles que estão correndo maior risco de abandonar a atividade por operarem com custos maiores decorrentes de tecnologias por vezes custosas e da mão-de-obra assalariadas. Esses produtores são, na prática, os que mais rapidamente abandonaram a atividade nos últimos anos (JANK, 1998). Já o produtor de pequena escala, consegue suportar altas oscilações de preços, uma vez que também produz animais de corte e se dedica a diversas atividades agrícolas em pequena escala.

Portanto, assegurar a permanência desse produtor em um mercado cada vez mais competitivo, em que novas exigências de qualidade vêm sendo adotadas, estudos tecnológicos devem ser desenvolvidos para a adequação de novas alternativas de geração de energia às atividades de produção de leite nas fazendas. 
Simultaneamente, políticas de compensação não excludentes devem ser implementadas, para que os custos sociais sejam diminuídos (SANT'ANNA et al., 2003).

\subsection{O Leite}

O leite pode ser definido como o fluido normalmente secretado pelas fêmeas dos mamíferos para a nutrição de suas crias. A intervenção na seleção e criação dos animais, como a vaca, tem aumentado tanto a qualidade como a capacidade produtiva do leite, tornando-o melhor para o consumo humano.

O leite, devido à sua riqueza de nutrientes, é considerado um alimento quase completo para o homem, e portanto amplamente comercializado e consumido pela população mundial. Na literatura, o termo leite é usado para indicar leite cru (in natura) produzido por vacas leiteiras. Para especificar uma outra origem do leite, o nome do animal produtor é adicionado.

\subsubsection{Composição do Leite}

O leite é composto basicamente por $87,5 \%$ de água e $13 \%$ de sólidos totais (com exceção da gordura, são chamados de sólidos não gordurosos) que estão suspensos ou dissolvidos na água (Tab. 2.2). O leite contém quantidades variadas de lipídios, proteínas e carboidratos que são sintetizados dentro da glândula mamária, bem como quantidades menores de minerais e outros componentes lipossolúveis e hidrossolúveis. 
Tabela 2.2. Composição quantitativa do leite de vaca

\begin{tabular}{ccc}
\hline Componente & Limites de variação $(\%)$ & Valor médio (\%) \\
\hline Água & $85,5-89,5$ & 87,5 \\
Sólidos totais & $10,5-14,5$ & 13,0 \\
Gordura & $2,5-6,0$ & 3,9 \\
Proteínas & $2,9-5,0$ & 3,4 \\
Lactose & $3,6-5,5$ & 4,8 \\
Minerais & $0,6-0,9$ & 0,8 \\
\hline
\end{tabular}

Fonte: Alfa Laval (1990)

O leite oferece condições excelentes para a multiplicação de microrganismos em curto espaço de tempo. As características físico-químicas do leite podem ser alteradas devido a alguns fatores tais como: nutricionais, ambientais, fraudes do produto. Por outro lado, as condições climáticas da região, higiene na ordenha e manejo do leite, entre outros, podem comprometer a qualidade microbiológica do leite.

A composição da população bacteriana do leite cru na fonte de produção depende da higiene das superfícies com que o leite entra em contato (filtros, latões de transporte, tanques, agitadores, etc.). Desse modo, o leite pode conter desde alguns milhares de bactérias por mililitro, em fazendas com boas práticas de higiene, até vários milhões se o padrão de limpeza, desinfecção e resfriamento forem ruins.

\subsubsection{Propriedades do Leite}

O leite é uma substância líquida dispersa num meio líquido, sendo considerado, portanto, uma emulsão, com as seguintes propriedades típicas (ALFA LAVAL, 1990):

- massa específica: 1.027 a $1.035 \mathrm{~kg} / \mathrm{m}^{3}\left(20^{\circ} \mathrm{C}\right.$, $\left.\mathrm{p}_{\mathrm{atm}}\right)$ 
- viscosidade dinâmica: $2,13 \times 10^{-3}$ Pa.s $\left(20^{\circ} \mathrm{C}\right)$

- $\mathrm{pH}: 6,4$ a 6,8 (para leite recém ordenhado)

- $\quad$ ponto de ebulição: $100,2^{\circ} \mathrm{C}$

- ponto de congelamento: de $-0,55^{\circ} \mathrm{C}$ a $0,53^{\circ} \mathrm{C}$, em função do valor do $\mathrm{pH}$ e da quantidade da lactose, entre outros fatores.

- Calor específico: 3,94 kJ/kg.C

O leite com alto teor de gordura apresenta maior densidade em relação ao leite com baixo teor de gordura, em razão do aumento do extrato seco desengordurado que acompanha o aumento no teor de gordura.

A qualidade do leite é controlada pelos institutos de saúde pública, por meio de testes específicos que envolvem a determinação da densidade, teor de gordura, rancidez, acidez e a presença de aditivos usados para conservação ou materiais estranhos ao leite para esconder a sua mistura com água, por exemplo.

\subsection{Tratamento do Leite}

O leite requer métodos adequados para sua extração, manejo, conservação e transporte, a fim de inibir a proliferação ou destruir microrganismos contaminantes. Em primeiro lugar, boas práticas de higiene durante a ordenha e manuseio são fundamentais para sua conservação. Um produtor que consegue controlar esses fatores apresenta um leite com menor contagem de agentes patogênicos.

Esses métodos podem ser físicos, químicos ou biológicos. Qualquer que seja o método para a conservação do leite, ele deve ser aplicado logo após a ordenha e o quanto antes possível, a fim de aproveitar a ação de alguns inibidores naturais presentes no leite durante a ordenha. Dentre os métodos físicos, a refrigeração e a pasteurização se destacam como os mais utilizados. 
A produção tradicional de leite cru envolve a ordenha manual e a utilização de latões para armazenagem e transporte por caminhão até o centro de beneficiamento. Nessa realidade, o transporte do produto representa um dos principais entraves ao desenvolvimento da atividade leiteira, pois a qualidade do produto é comprometida por conta do tempo que o leite é mantido a temperaturas inadequadas (falta de refrigeração).

Segundo o tratamento aplicado na fazenda, a IN51 estabeleceu graus e padrões para o leite, denominando de leite tipo A, ao leite pasteurizado e empacotado na fazenda, leite tipo $\mathrm{B}$ ao leite resfriado na fazenda e processado em uma planta especializada (centro de processamento) e leite tipo $\mathrm{C}$ ao leite coletado sem tratamento térmico na fazenda e/ou resfriado somente em centros de coleta de plantas de processamento.

Sob essa padronização, o produtor leiteiro determina, dentro de suas possibilidades, que tipo de leite é capaz de produzir a fim de formalizar o contrato de compra-venda com a planta coletora. Muitas vezes, como mencionado anteriormente, baixos volumes de produção de leite inviabilizam a aquisição individual de um resfriador adequado, e por isso têm surgido, por intermédio de cooperativas, pontos de coleta e/ou Centros de Coleta de Leite (CCL), para manter o pequeno produtor no mercado.

O ponto de coleta é um tanque coletivo em que o leite é depositado em até duas horas após a ordenha, conforme a legislação brasileira, e transportado pela coletora. Já no CCL o leite deve ser coletado e resfriado a menos de $4^{\circ} \mathrm{C}$ até no máximo 3 horas após a ordenha, e sua capacidade varia de 500 a 16.000 litros/dia (DELAVAL, 2005).

Transportar o leite resfriado de um tanque de armazenamento da fazenda ou do CCL representa uma grande vantagem para os laticínios em termos de logística, uma vez que estes podem organizar um sistema de transporte mais eficiente, em que a coleta pode ser feita a qualquer hora do dia e com frequiências maiores ( 2 a 3 dias), evitando-se gerar horários de pico na operação de recepção do leite no centro de processamento. 


\subsubsection{Resfriamento do Leite}

A conservação do leite mediante o resfriamento é imprescindível em todas as fases de beneficiamento do leite. Seu uso ainda é limitado principalmente por problemas técnicos e socioeconômicos, geralmente de difícil solução em curto prazo. Para os produtores de pequena escala nem sempre é possível justificar a implementação do resfriamento de leite cru, pois os baixos volumes do produto junto com fatores como investimento, manutenção, limitações técnicas, controle de alta complexidade, etc., na maioria dos casos, influenciam na decisão.

$\mathrm{Na}$ fazenda, o resfriamento é requerido já que inibe o crescimento bacteriano, e prolonga o armazenamento na fazenda, diminuindo os custos de transporte.

No resfriamento do leite, a temperatura adequada de armazenamento é tão importante quanto o tempo requerido para atingi-la. Abaixo de $10^{\circ} \mathrm{C}$ tanto os processos químicos como o crescimento microbiano é retardado e a qualidade do leite é mantida. Já com temperaturas menores a $5^{\circ} \mathrm{C}$, essas atividades são quase que interrompidas (ALFA LAVAL, 1990).

Na fazenda o leite é extraído mediante ordenha manual ou mecânica com uma temperatura aproximada de $38^{\circ} \mathrm{C}$. Com a manipulação (ordenha, transporte, armazenamento, etc.) essa temperatura cai para cerca de $35^{\circ} \mathrm{C}$. No processo de resfriamento, o leite é levado para os $4^{\circ} \mathrm{C}$ (valor ideal) por meio do contato térmico com um portador frigorífico (agente refrigerante).

Para o dimensionamento de um sistema adequado que atenda certa demanda e que garanta um resfriamento eficiente, é preciso conhecer:

- o volume diário de produção de leite;

- o número de ordenhas por dia;

- as condições climáticas;

- disponibilidade de tecnologia adequada. 


\subsubsection{Retribuições econômicas}

Os consumidores, geralmente mal informados, consideram que o produto vindo direto do sítio (fazenda) é melhor que o produto processado. Conseqüentemente, cria-se uma oportunidade de produtores não-especializados se manterem no mercado, representando um atraso à modernização do setor leiteiro.

Como parte do incentivo à especialização da produção de leite vem-se implantando formas de pagamento diferenciado. Por exemplo, bonificações por qualidade e volume de leite já são praticadas por algumas empresas (SBRISSIA e PONCHIO, 2004), Embora uma bonificação por volume não garanta um leite de qualidade, permite ao centro de processamento planejar a logística de suas operações.

Os incentivos outorgados pelas plantas processadoras aos produtores para investirem no resfriamento do leite in loco, derivam da redução de custos de investimento, operação e manutenção correspondentes às labores de limpeza, esterilização, resfriamento e transporte, entre outros. Essa economia é repassada aos produtores (VEIGA DOS SANTOS e FONSECA, 2003).

Os benefícios por resfriamento do leite são repassados ao produtor em forma de 2 incentivos sobre o preço do leite. O primeiro corresponde a um incremento de $5 \%$ por entrega de leite frio e o segundo consiste na redução de $50 \%$ dos custos de transporte tradicional (SANT'ANNA et al., 2003).

Sendo o custo de investimento proporcional ao tamanho do tanque resfriador de leite e inversamente proporcional ao risco de investimento, tais incentivos podem não ser suficientes para o pequeno produtor adotar o resfriamento de leite in loco. Por isso, o resfriamento coletivo é apontado como uma solução plausível no curto prazo, considerada como uma estratégia sustentável para a criação de cooperativas e difusão de tecnologias de alimentação e criação do rebanho, por meio de assessoria técnica.

O recenseamento das cooperativas leiteiras de 2002 mostrou que os produtores recebiam incentivos por volume de leite entregue aos laticínios, correspondente a 5 $10 \%$ sobre o preço médio do leite (cf. FARINA et al., 2005). Na Tab. 2.3 são 
mostrados os preços médios praticados por alguns laticínios e cooperativas nas 5 principais bacias leiteiras.

O informe econômico da EMBRAPA (2003) caracteriza os custos de produção do leite nas 5 principais regiões do país (Tab. 2.4). Com referência nesses custos e nos custos associados com o resfriamento do leite, pode ser determinada qual a economia esperada pelo produtor se inserir essa tecnologia dentro de sua atividade produtiva.

Tabela 2.3. Preço médio recebido pelos produtores de leite tipo C em julho de 2005

\begin{tabular}{cc}
\hline Estado & Preço líquido (R $\$ /$ litro) \\
\hline PR & 0,4832 \\
RS & 0,4985 \\
GO & 0,5316 \\
SP & 0,5454 \\
MG & 0,5472 \\
Média & 0,5212 \\
\hline
\end{tabular}

Fonte: CEPEA (2005)

Tabela 2.4. Custo de produção de leite nas 5 principais bacias leiteiras do Brasil, agosto de 2000 a julho de 2001

\begin{tabular}{cccc}
\hline Região & $\begin{array}{c}\text { Custo capital } \\
(\mathrm{R} \$ / \text { litro })\end{array}$ & $\begin{array}{c}\text { Custo variável } \\
(\mathrm{R} \$ / \text { litro })\end{array}$ & $\begin{array}{c}\text { Custo total } \\
(\mathrm{R} \$ / \text { litro })\end{array}$ \\
\hline GO & 0,055 & 0,228 & 0,283 \\
MG & 0,047 & 0,258 & 0,305 \\
SP & 0,058 & 0,282 & 0,340 \\
PR & 0,041 & 0,218 & 0,258 \\
RS & 0,041 & 0,215 & 0,256 \\
Média & 0,0481 & 0,2400 & 0,2881 \\
\hline
\end{tabular}

Fonte: EMBRAPA (2003) 
Com o intuito de financiar a realização de investimentos em equipamentos de resfriamento e coleta a granel para produtores de leite, necessários para a modernização da produção leiteira, por meio da resolução $\mathrm{n}^{\circ} 3.088 / 2003$ criou-se o PROLEITE, um dos programas especiais de apoio ao setor agroindustrial operado pelo BNDES (Banco de Desenvolvimento Econômico e Social) por meio de instituições financeiras credenciadas o financiamento (FAO, 2004). Na Tab. 2.5 são mostradas algumas das principais características desse programa.

Tabela 2.5. Principais características do PROLEITE

\begin{tabular}{cc}
\hline Parâmetros & Características e valores \\
\hline Taxa de juros & $8,75 \%$ \\
Amortização & Mensal ou semestral \\
Prazo total & 60 meses \\
Nível de participação & Até $100 \%$ \\
Limite de valor do financiamento & R $\$ 80.000$ por cliente* \\
Garantias & Acordadas entre a instituição credenciada e o cliente \\
\hline
\end{tabular}

* No caso de uma cooperativa esse valor pode ser repassado a cada um dos participantes; por exemplo, para 10 participantes o montante do financiamento não poderá exceder R $\$ 800.000$.

Fonte: FAO (2004) 


\section{TECNOLOGIAS DE DIGESTÃo ANAERÓBICA E PRODUÇÃo DE BIOGÁS}

\subsection{Introdução}

Hoje em dia, no mundo, fatores como a disponibilidade de energia, a otimização de processos e as crescentes exigências ambientais vêm promovendo o desenvolvimento sustentável para o acompanhamento do crescimento econômico dos países. Os sistemas energéticos baseados em fontes renováveis de energia vem contribuindo com esse objetivo, cumprindo um papel importante na substituição do petróleo e derivados.

Dentre essas fontes, no setor pecuário, destaca-se o biogás, produto do gerenciamento dos detritos animais por digestão anaeróbica, cuja captura e combustão representa uma forma relativamente simples de reduzir emissões de metano, disponibilizar um combustível e até gerar uma receita adicional por meio da geração de créditos de carbono mediante a implantação de projetos MDL.

A instalação de um biodigestor no meio rural também surge como uma solução para evitar a degradação da terra, devido à redução no consumo de lenha (biomassa) como combustível. Portanto sua viabilidade não pode considerar apenas o retorno financeiro, mas também outros aspectos sociais e ambientais, tais como a melhoria da qualidade de vida de mulheres e crianças, uma vez que se elimina o trabalho de coletar lenha, conseqüentemente diminuem o desmatamento, reduzem-se as emissões de CO na cozinha e a fuligem típica da queima de lenha (PRESTON e RODRIGUEZ, 2002). 


\subsection{A Digestão Anaeróbica no Mundo}

A inserção do processo de digestão anaeróbica dentro das atividades humanas, trouxe como resultado benefícios energéticos, ambientais e econômicos, principalmente como decorrência da redução de até $90 \%$ da matéria orgânica produzida, por meio do confinamento dos detritos animais e restos de cultura na ausência de oxigênio em câmaras de fermentação, chamados de biodigestores, digestores ou plantas de biogás.

O aproveitamento das propriedades combustíveis e fertilizantes dos produtos da degradação da matéria orgânica, o biogás e o efluente, respectivamente, incentivou a disseminação da tecnologia da Digestão Anaeróbica (DA). Países como a Índia (a partir da década de 1960) e a China (a partir da década de 1970) implementaram programas nacionais de construção de digestores para atender às demandas básicas de energia, como a cocção de alimentos e iluminação. Segundo Gustavsson (2000), dentro do programa de extensão e desenvolvimento implantado pelo governo indiano, até o ano de 1996 haviam sido instalados 2,6 milhões de digestores.

Por outro lado, nos países industrializados, principalmente da Europa, o incentivo à utilização dessa tecnologia foi motivado mais por questões ambientais do que puramente energéticas. Em 2002, a produção de biogás na Europa foi de aproximadamente 92 PJ/ano (7,4 milhões de tep ${ }^{3}$ ). Para o ano de 2020 se estima uma produção de 770 PJ/ano (62 milhões de tep). Jonsson (2004) estima que nesse ano havia mais de 4.500 plantas de biogás na Europa.

Na Alemanha, no final do ano de 2001, havia 1.650 digestores instalados na área rural (com volumes de 200 a $700 \mathrm{~m}^{3}$ ) para geração de eletricidade a partir de esterco de vaca (principalmente) e de porco, sendo eventualmente adicionados restos de cultura, grãos e outros (SOGARI, 2003).

\footnotetext{
${ }^{3}$ tep $=$ tonelada equivalente de petróleo
} 
Na Dinamarca, os Ministérios da Agricultura, Energia e Meio Ambiente iniciaram em 1985 um programa conjunto para avaliar o potencial de grandes plantas de digestão anaeróbica como produtores de energia elétrica. Assim, em 199719 grandes plantas tratavam conjuntamente resíduos de origem industrial, urbana e resíduos de gado, com metas de duplicar a produção para o ano 2000, e continuar aumentando até 2030 (AHRING e ANGELIDAKI, 1997).

Em 1994, a Agência de Proteção ao Meio Ambiente (EPA) dos EUA implantou o programa AgSTAR, em conjunto com os departamentos de Agricultura e de Energia, para promover o uso adequado de sistemas de gerenciamento de esterco visando a redução da emissão de poluentes, mediante a implantação da tecnologia da digestão anaeróbica.

Segundo relatórios desse programa, em 2002 eram 40 plantas de biogás operando em fazendas dos EUA (suinocultura: 9, pecuária leiteira: 29, avicultura: 1, criação de patos: 1). Eletricidade e calor eram produzidos por $87.5 \%$ dessas plantas. Assim mesmo, instalaram-se três sistemas centralizados para o tratamento do esterco de fazendas vizinhas. Conseguiu-se uma redução acumulada de aproximadamente 124.000 toneladas de carbono-equivalente e uma geração de cerca de 30 milhões de kWh (AGSTAR, 2002).

No Brasil, com as crises do petróleo, na década de 1970, foi trazida a tecnologia dos biodigestores, sendo os principais modelos implantados o Chinês e o Indiano. Na região Nordeste, foram implantados programas para a difusão dos biodigestores, mas os benefícios trazidos pelo biogás e o biofertilizante, subprodutos de excelente qualidade, não foram suficientes, à época, para dar continuidade a esses programas.

Na Paraíba, por exemplo, na década de 1980 a EMATER (Empresa de Assistência Técnica e Extensão Rural) implantou, em convênio com o Ministério de Minas e Energia, cerca de 200 biodigestores em propriedades rurais. Em 1999, segundo avaliação do Núcleo de Energia da Universidade Federal da Paraíba, desse universo apenas nove $(4,6 \%)$ estavam em funcionamento e a quase totalidade dos proprietários não desejavam reativar os demais (ROSTAND, 2004). 


\subsection{O Processo de Digestão Anaeróbica}

A Digestão Anaeróbica (DA) consiste em um processo de dois estágios para decompor a matéria orgânica (sólidos voláteis) na ausência de oxigênio, produzindo biogás como produto residual. No primeiro estágio, os sólidos voláteis (SV) são convertidos em ácidos graxos por bactérias anaeróbicas conhecidas como formadoras de ácidos. No segundo estágio, os ácidos são convertidos em biogás por outras bactérias conhecidas como formadoras de metano.

Para entender melhor a tecnologia do biogás, pode-se imaginar a planta de biogás como uma caixa-preta (Fig. 3.1) em que basicamente três insumos são transformados em dois produtos. Aspectos econômicos, experiência e disponibilidade de espaço devem também ser considerados.

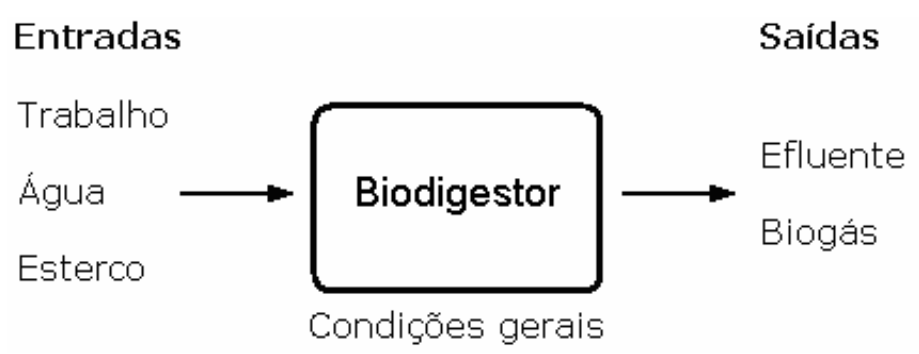

Figura 3.1. Estrutura de caixa-preta para o biodigestor.

Dentre as atividades agropecuárias, a suinocultura e a bovinocultura tem-se destacado como as principais fontes para recuperação de biogás, a primeira por apresentar um elevado potencial de produção de biogás ( $\mathrm{m}^{3}$ de biogás/kg de esterco), e a segunda por produzir grande quantidade de esterco ( $\mathrm{kg}$ de esterco/vaca).

A produção diária de esterco fresco (sólidos e líquidos) de vacas leiteiras varia principalmente em função do tipo e idade biológica do animal (vaca leiteira, novilha, 
boi, bezerro, entre outros) e sua alimentação. Para Generoso (2001) esses dejetos representam de 8 a $11 \%$ do peso do animal. Já Gaspar (2003) considera um fator de produção de $0,019 \mathrm{~kg}$ de esterco por unidade de peso $(\mathrm{kg})$ da vaca. Verastegui e Matero (1979), por sua vez, consideram uma produção de $16 \mathrm{~kg}$ por vaca (Tab. 3.1). Independentemente da quantidade exata de esterco produzido, torna-se necessário o seu manejo adequado a fim de evitar a acumulação e suas conseqüências (emissões poluentes, mau cheiro, atração de moscas, entre outras).

A valorização dos produtos da digestão anaeróbica pode atender algumas das necessidades básicas dos fazendeiros. O biogás apresenta propriedades combustíveis que podem ser aproveitadas na geração de energia e o efluente pode ser utilizado como adubo para os cultivos devido a suas propriedades fertilizantes.

Tabela 3.1. Produção de biogás a partir de diferentes substratos

\begin{tabular}{|c|c|c|c|c|c|}
\hline \multirow{3}{*}{ Substrato } & \multicolumn{5}{|c|}{ Rendimento } \\
\hline & \multicolumn{2}{|c|}{ Dejetos $^{*}$} & \multicolumn{3}{|c|}{ Biogás } \\
\hline & (kg/unid./ano) & (kg/unid./dia) & $\left(\mathrm{m}^{3} / \mathrm{kg}_{\text {fresco }}\right)$ & (m³/unid./ano) & ( $\mathrm{m}^{3} /$ unid./dia) \\
\hline $\begin{array}{c}\text { Esterco de } \\
\text { vaca }\end{array}$ & $6.000,00$ & 16,44 & 0,04 & 223,00 & 0,61 \\
\hline $\begin{array}{l}\text { Esterco de } \\
\text { cavalo }\end{array}$ & $5.000,00$ & 13,70 & 0,06 & 286,00 & 0,78 \\
\hline $\begin{array}{l}\text { Esterco de } \\
\text { porco }\end{array}$ & $3.000,00$ & 8,22 & 0,05 & 156,00 & 0,43 \\
\hline $\begin{array}{c}\text { Esterco de } \\
\text { ovelha }\end{array}$ & 800,00 & 2,19 & 0,15 & 121,00 & 0,33 \\
\hline $\begin{array}{l}\text { Esterco de } \\
\text { aves }\end{array}$ & 25,00 & 0,07 & 0,09 & 2,28 & 0,01 \\
\hline $\begin{array}{l}\text { Esterco } \\
\text { humano }\end{array}$ & 250,00 & 0,68 & 0,04 & 12,00 & 0,03 \\
\hline $\begin{array}{l}\text { Restos de } \\
\text { milho }\end{array}$ & $9.988,00$ & 27,36 & 0,19 & $1.898,00$ & 5,20 \\
\hline $\begin{array}{c}\text { Restos de } \\
\text { arroz }\end{array}$ & $3.379,00$ & 9,26 & 0,19 & 642,00 & 1,76 \\
\hline
\end{tabular}

* por unidade animal/humano ou hectare

Fonte: Verástegui e Matero (1979) 


\subsubsection{Fatores que Afetam a Digestão Anaeróbica}

A eficiência do processo de digestão (volume de biogás produzido por quilograma de material digerível) depende basicamente dos seguintes fatores:

- temperatura: afeta diretamente a velocidade do metabolismo das bactérias, o equilíbrio iônico e a solubilidade dos substratos; a temperatura de trabalho deve ser adotada segundo a disponibilidade de recursos para instalação de um sistema de aquecimento no biodigestor, verificando-se o custo - benefício;

- composição do substrato orgânico: principal responsável pela qualidade e quantidade de gás produzido, varia com a qualidade de alimentação, a idade biológica e o tipo de animal; a Tab. 3.1 compara o rendimento de alguns substratos;

- Tempo de Retenção Hidráulica (TRH): tempo que o substrato orgânico deve permanecer no digestor para que seja digerido pelas bactérias anaeróbicas;

- acidez/alcalinidade: é necessário manter sempre o $\mathrm{pH}$ na faixa de 6,0 a 8,0, para assegurar a estabilidade do processo de digestão da matéria orgânica;

- substâncias tóxicas: a entrada de desinfetantes e sarnicidas, dentre outros, podem paralisar a atividade bacteriana.

\subsection{Tipos de Biodigestor}

Um sistema adequado de recuperação de biogás considera fatores como a quantidade de esterco a ser manejada, o tipo de criação (pastagem ou confinamento) e a freqüência de captação do esterco, assim como a disponibilidade de água. Para a seleção da opção adequada, aspectos financeiros, econômicos (custo de investimento, operação e manutenção), assim como a destreza necessária para manter e reparar o biodigestor, devem ser considerados.

A prática ensina que um biodigestor deve ser desenvolvido de acordo com as necessidades do local no momento da instalação. Já no dimensionamento devem ser considerados outros parâmetros como o tempo de retenção, a profundidade da 
câmara de fermentação, a relação largura/comprimento e a caixa de carga e de descarga.

Segundo Harris (1998), os biodigestores podem ser classificados, de acordo com o princípio de operação, em:

- descontínuos (batch);

- de expansão contínua (continuously expanding);

- de fluxo contínuo (continuous flow);

- de fluxo de corrente (plug flow);

- de contato.

Os mais difundidos são os digestores descontínuos (ou em batelada) e os de fluxo contínuo. Ambos, basicamente, contam com uma câmara de fermentação, um acesso de carga e outro de descarga, e uma saída de biogás. Os descontínuos foram os primeiros a serem utilizados, são carregados de uma só vez e mantidos fechados por um período de 20 a 50 dias, dependendo da temperatura de operação, até a produção de biogás cair sensivelmente. Posteriormente, a matéria orgânica fermentada é descarregada. É recomendado para operação com materiais orgânicos de decomposição lenta ou para locais em que a disponibilidade de material é periódica. Segundo Ortolani et al. (1991), modelos desse tipo são utilizados em áreas rurais do Brasil.

Os biodigestores de fluxo contínuo apresentam carregamento periódico, geralmente diário, e praticamente uma produção constante de biogás e efluente. Com isso, são muito utilizados quando se dispõe de fornecimento regular de matéria prima, como o esterco de gado, sendo muito utilizados em comunidades rurais de pequeno e médio porte.

Existem duas plantas de biogás básicas que tem se popularizado em práticas agropecuárias: as de campana flutuante e as de domo fixo, sendo o modelo indiano e 
o modelo chinês os mais difundidos, respectivamente. Segundo Benincasa et al. (1990), cada metro cúbico da câmara de fermentação pode produzir, à temperatura de 30-35 ${ }^{\circ} \mathrm{C}$, de 0,15 a $0,20 \mathrm{~m}^{3}$ de biogás/dia, requerendo geralmente um TRH de 30 a 50 dias, dependendo da temperatura onde o biodigestor esteja instalado.

\subsubsection{Biodigestor Tipo Indiano}

Este biodigestor (Fig. 3.2) caracteriza-se por dispor de uma cúpula móvel de ferro ou de fibra de vidro. À medida que o gás se forma vai sendo armazenado sob a cúpula. Devido à formação incessante de gás, este mantém uma pressão constante que permite usá-lo ininterruptamente. Apresenta uma parede central que divide o tanque de fermentação em duas câmaras, permitindo a separação da biomassa já fermentada e sua posterior descarga (BENINCASA et al., 1990).

A capacidade da planta varia segundo o tamanho da propriedade rural. Assim um biodigestor com capacidade de 5 a $15 \mathrm{~m}^{3}$ é usado em propriedades pequenas e médias e de 20 a $100 \mathrm{~m}^{3}$ em grandes propriedades (WERNER et al., 1989).

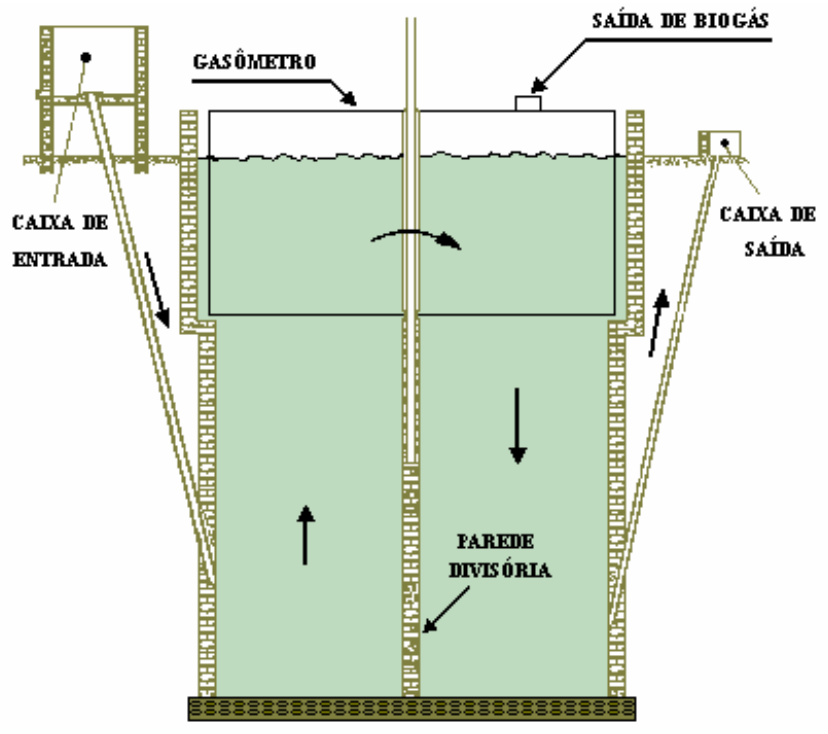

Figura 3.2. Biodigestor modelo indiano

Fonte: Benincasa et al. (1990) 
Por ser construído enterrado no solo o processo de fermentação sofre pouca variação de temperatura, e dispensa o uso de reforços nas paredes, o que diminui o custo de instalação. A cúpula metálica está sujeita à corrosão, e a comunicação por meio de tubos, entre a caixa de carga e a câmara, pode entupir ocasionalmente.

\subsubsection{Biodigestor Tipo Chinês}

Este é formado por uma câmara cilíndrica de alvenaria para a fermentação e um teto abobadado, impermeável, destinado ao armazenamento do biogás (Fig. 3.3). O reator funciona com base no princípio de prensa hidráulica, de modo que há aumentos da pressão do gás no interior do biodigestor, o que desloca a biomassa da câmara de fermentação para a caixa de saída e em sentido contrário, quando há descompressão (BENINCASA et al., 1990). É o modelo mais indicado para a produção de biofertilizante, pois possui uma cúpula fixa que permite pouca acumulação de gás. Ocupa pouco espaço na superfície do solo e está sujeito a pouca variação da temperatura de trabalho por estar completamente enterrado (digestor e gasômetro). É mais barato que os demais, pois a cúpula é feita de alvenaria, e por isso normalmente requer seladores especiais, por conta da porosidade na alvenaria.

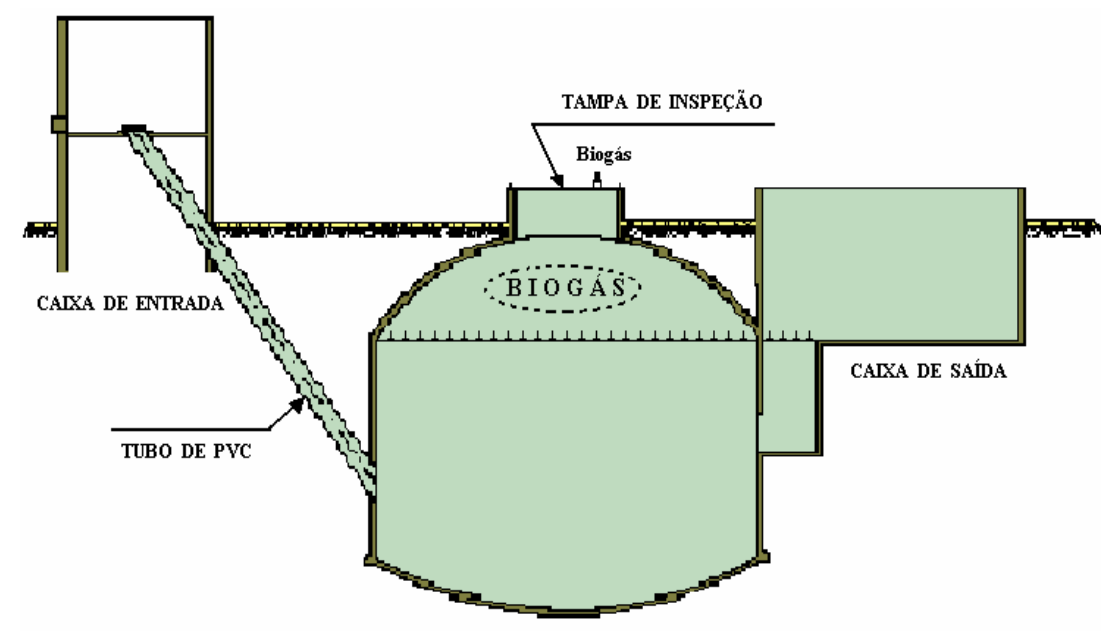

Figura 3.3. Biodigestor modelo chinês

Fonte: Benincasa et al. (1990) 


\subsubsection{Biodigestor Tipo Lagoa Coberta (Covered-Lagoon)}

Nesse tipo de biodigestor a captura do biogás é feita por uma coberta hermética

instalada sobre uma vala na qual é depositado o substrato. É mais usado em regiões quentes, onde o próprio ambiente ajuda a manter a temperatura no biodigestor. Esse é o modelo com menores custos de instalação e operação (Fig. 3.4). Os dejetos são manejados como líquido, portanto muito aplicado em fazendas leiteiras que usam água para lavar as instalações (curral, estábulo, sala de ordenha, entre outras) e com conteúdo de sólidos menor a $2 \%$. Usualmente tem uma taxa de carga de sólidos voláteis de $0,1 \mathrm{~kg} / \mathrm{m}^{3}$ (BALSAM, 2002).

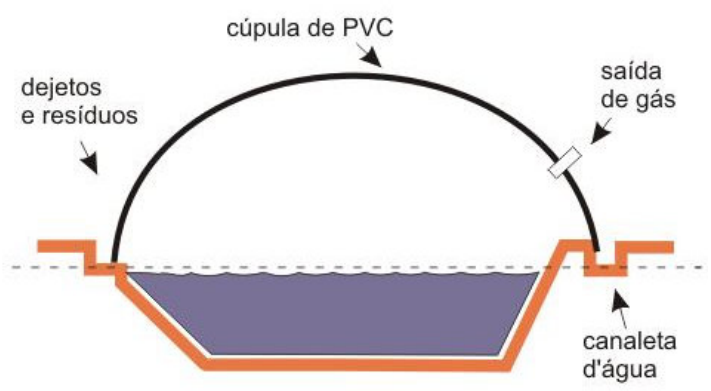

Figura 3.4. Biodigestor de coberta hermética de PVC

Fonte: Recolast (2006)

\subsubsection{Digestor Tipo Mistura Completa (Complete-Mix Digester)}

Consiste num silo (tanque) com cobertura hermética, no qual o esterco é aquecido e misturado. É o sistema com maior custo de instalação e operação, projetados para manejar esterco com 2 a $10 \%$ de sólidos totais. O esterco é conduzido para um tanque de pré-tratamento e mistura, onde é adicionada água ou esterco sólido para obter a concentração ótima de sólidos voláteis de $1,2 \mathrm{~kg} / \mathrm{m}^{3}$. São mais eficientes do que os anteriores porque são aquecidos e misturados (BALSAM, 2002). 


\subsubsection{Digestor de Fluxo de Corrente (Plug-Flow Digester)}

Consiste em um tanque circular, no qual o esterco é alimentado por um terminal (de entrada), deslocando uma quantidade similar no outro terminal (de saída). É mais apropriado para operações que removem o esterco mecanicamente. O esterco é pré-tratado num tanque de mistura antes de entrar no digestor. São de volume constante, não misturados, com controle de temperatura e manejam esterco com concentração de sólidos totais acima de 10\% (BALSAM, 2002).

\subsubsection{Digestor de Polietileno de Baixo Custo (Low-Cost Digester)}

Os grandes investimentos requeridos na construção de estruturas fixas têm provado ser o principal impedimento para que pequenos empreendedores rurais adotem a tecnologia da digestão anaeróbica. Na década de 1960, isso motivou os engenheiros de uma província de Taiwan a criar biodigestores com materiais flexíveis de menor custo. Inicialmente foram utilizados nylon e borracha sintética (neoprene), mas se mostraram relativamente custosos (AN et al., 1997).

O maior desenvolvimento aconteceu nos anos 1970, quando foram combinados PVC com resíduos da refinarias de alumínio para produzir o produto chamado red mud PVC. Posteriormente, ele foi substituído por polietileno de baixo custo, nascendo o biodigestor plástico de baixo custo (Fig. 3.5), que se tornou o mais comum na América Latina, Ásia e África (AN et al., 1997).

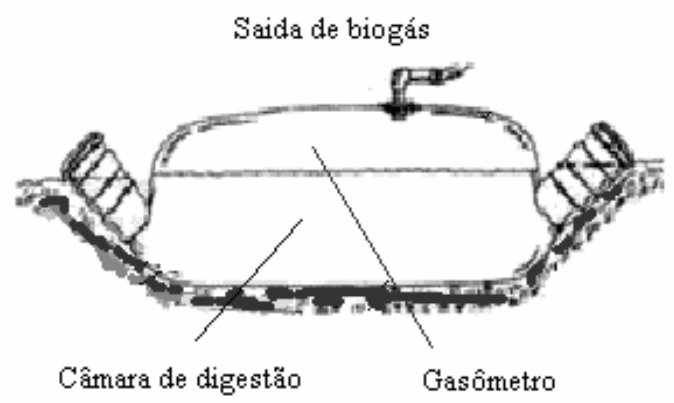

Figura 3.5. Biodigestor plástico de baixo custo

Fonte: Recolast (2006) 


\subsection{O Biogás}

O biogás é basicamente uma mistura de metano e gás carbônico, além de outros gases em pequenas quantidades. Essa composição, assim como sua taxa de produção, indica a eficiência do processo de DA e são usados como parâmetros no controle da digestão, verificando alterações no processo de fermentação.

A determinação da taxa volumétrica de metano é importante para os estudos da cinética da fermentação anaeróbica. Sua intensificação tem contribuído para um melhor entendimento do processo biológico do tratamento de resíduos e do desenho de reatores, bem como para predizer a estabilidade desses sistemas, a qualidade dos efluentes e a estabilização dos resíduos (CAETANO, 1985).

Dentre os parâmetros termodinâmicos mais importantes do biogás, pode-se destacar o poder calorífico e a densidade, que influenciam na operação do equipamento conversor e no dimensionamento dos equipamentos de armazenamento e compressão, respectivamente.

Esses parâmetros variam segundo com a composição do biogás (Tab. 3.2), que por sua vez, variam com a qualidade da matéria orgânica e as características do processo de digestão, principalmente. No geral, considera-se que o poder calorífico inferior (PCI) de um biogás com conteúdo de 50 a $80 \%$ de metano, varia entre 17.820 e $28.440 \mathrm{~kJ} / \mathrm{m}^{3}$. Já o metano puro em condições normais $(\mathrm{p}=1,0 \mathrm{~atm}$, $\mathrm{T}=0^{\circ} \mathrm{C}$ ) tem um valor de $35.640 \mathrm{~kJ} / \mathrm{m}^{3}$ (CCE apud BAYER et al., 2000).

Tabela 3.2. Composição típica do biogás

\begin{tabular}{cc}
\hline Componente & Biogás \\
\hline $\mathrm{CH}_{4}$ (metano), \% em volume & $55-70$ \\
$\mathrm{CO}_{2}$ (dióxido de carbono), \% em volume & $30-45$ \\
$\mathrm{~N}_{2}$ (nitrogênio), \% em volume & $0-2$ \\
$\mathrm{H}_{2} \mathrm{~S}$ (gás sulfídrico), ppm & $\sim 500$ \\
$\mathrm{NH}_{3}$ (amoníaco), ppm & $\sim 100$ \\
\hline
\end{tabular}

Fonte: Jensen e Jensen (2000) 
Por outro lado, Wright (2001) afirma que para um biogás com $60 \% \mathrm{CH}_{4}$ e $40 \%$ de $\mathrm{CO}_{2}$, apresenta um PCI é de $20.120 \mathrm{~kJ} / \mathrm{m}^{3}$ (considerando para o metano, 33.980 $\mathrm{kJ} / \mathrm{m}^{3}$ nas CNPT). Já, Jensen e Jensen (2000) atribuem ao biogás um conteúdo energético médio da ordem de $23.300 \mathrm{~kJ} / \mathrm{m}^{3}$. A Tab. 3.3 apresenta a equivalência entre o biogás e os combustíveis mais utilizados na área rural.

Tabela 3.3. Equivalência aproximada de $1,0 \mathrm{~m}^{3}$ de biogás

\begin{tabular}{cc}
\hline Combustível & Equivalência \\
\hline Gás Natural & $0,60 \mathrm{~m}^{3}$ \\
Propano & 0,881 \\
Butano & 0,791 \\
Gasolina & 0,631 \\
Óleo combustível & 0,571 \\
Carvão betuminoso & $0,70 \mathrm{~kg}$ \\
Lenha úmida (10\%) & $1,60 \mathrm{~kg}$ \\
\hline
\end{tabular}

Fonte: Walsh et al. (1988)

\subsubsection{Utilização do Biogás}

As propriedades combustíveis do biogás podem ser aproveitadas pelo produtor rural para geração de energia e suprimento da demanda energética própria da atividade desenvolvida, como a produção de leite, por exemplo, enquanto as emissões de metano são reduzidas. Um projeto típico para a geração de energia a partir de biogás consiste, basicamente, de um biodigestor, um sistema de manejo do gás e um equipamento conversor.

Dos usos finais do biogás, a combustão direta e a operação de motores de combustão interna, são os mais comuns em explorações rurais de pequeno, e de meio e grande porte, respectivamente (Tab. 3.4).

Segundo Werner et al. (1989) a produção de biogás de um biodigestor simples com volume de 8 a $10 \mathrm{~m}^{3}$ é da ordem de 1,5 a $2,0 \mathrm{~m}^{3} / \mathrm{dia}$, usando o esterco de 3 a 5 
cabeças de gado ou 8 a 12 porcos. Essa quantidade é suficiente para que uma família com 6 a 8 membros possa cozinhar de 2 a 3 refeições, ou operar uma geladeira por todo o dia e duas lâmpadas por 3 horas, ou operar um moto-gerador de $3 \mathrm{~kW}$ por 1 hora.

Tabela 3.4. Usos finais do biogás

\begin{tabular}{cc}
\hline Utilização & Consumo \\
\hline Cocção para uma pessoa & $0,24-0,33 \mathrm{~m}^{3} / \mathrm{dia}$ \\
Iluminação (lâmpada 40W) & $0,283 \mathrm{~m}^{3} / \mathrm{h}$ \\
Iluminação (lampião) & $0,12 \mathrm{~m}^{3} / \mathrm{h}$ \\
Geração de Eletricidade & $0,62 \mathrm{~m}^{3} / \mathrm{kWh}$ \\
Geladeiras por absorção & $0,7-2,5 \mathrm{~m}^{3} / \mathrm{dia}$ \\
Acionamento de MCI & $0,424 \mathrm{~m}^{3} / \mathrm{h} / \mathrm{HP}$ \\
\hline
\end{tabular}

Fonte: Massotti (2003); Werner et al. (1989)

\subsubsection{Tratamento do Biogás}

O processo a ser empregado para a purificação depende da composição e aplicação do biogás, características físicas, energia e recursos disponíveis, subprodutos gerados e do volume do gás a ser tratado. Assumindo um grau de purificação suficiente do biogás, este pode ser utilizado em todas as aplicações projetadas para gás natural (ZICARI, 2003).

A remoção do $\mathrm{CO}_{2}$ diluído no $\mathrm{CH}_{4}$ permite elevar o poder calorífico do biogás e facilita a compressão do biogás (WALSH et al., 1988; JENSEN e JENSEN, 2000). Já a remoção do sulfeto de hidrogênio $\left(\mathrm{H}_{2} \mathrm{~S}\right)$ evita a deterioração prematura das máquinas transformadoras de energia, pois este sulfeto, quando misturado com água, forma ácido sulfídrico, que é altamente corrosivo.

Zicari (2003), divide os processos de purificação de gás em 5 categorias:

- $\quad$ absorção por um líquido; 
- $\quad$ adsorção por um sólido;

- $\quad$ separação por diferença de permeabilidade em membrana;

- conversão química em outro componente;

- condensação.

Dentre esses, o uso de lã de ferro tem-se popularizado como uma técnica acessível e de baixo custo relativo para remoção do $\mathrm{H}_{2} \mathrm{~S}$, por meio do processo de corrosão desse material. Esse material é muito utilizado em pequenos biodigestores rurais (RODRIGUEZ et al., 1998).

Para Magalhães et al. (2004) a lavagem com água (water scrubber technology) representa a tecnologia mais usada na purificação do biogás. Em uma primeira etapa o $\mathrm{CO}_{2}$ é removido e em seguida remove-se o resto de contaminantes, presentes em menores concentrações $\left(\mathrm{H}_{2} \mathrm{~S}\right.$, por exemplo).

Os autores construíram e avaliaram um sistema simples, versátil e de baixo custo, aproveitando a grande solubilidade do $\mathrm{CO}_{2}$ e do $\mathrm{H}_{2} \mathrm{~S}$ na água conseguiram uma remoção de $18 \%$ do conteúdo original de $\mathrm{CO}_{2}$ (inicialmente $33 \%$ ), resultando em um biogás com $85 \%$ de metano; um incremento de $27 \%$ no poder calorífico $\left(23.760\right.$ para $\left.30.240 \mathrm{~kJ} / \mathrm{m}^{3}\right)$ e uma redução de $20 \%$ na massa específica $(0,88$ para $\left.0,71 \mathrm{~kg} / \mathrm{m}^{3}\right)$.

Em 2003, o Centro de Gás da Suécia (SGC) avaliou o desempenho técnicoeconômico da purificação do biogás em 11 plantas, com maior experiência de operação, determinando que os custos associados são proporcionais com o tamanho de planta. Nas plantas maiores (200 a $300 \mathrm{~m}^{3} / \mathrm{h}$ ) esse custo representa cerca de um terço do custo de uma planta menor $\left(100 \mathrm{~m}^{3} / \mathrm{h}\right)$ (SGC, 2005).

\subsection{O Biofertilizante}

O efluente, um outro subproduto da digestão anaeróbica, apresenta uma alta qualidade para o uso como fertilizante agrícola, pois contêm matéria orgânica com 
teor reduzido de carbono (por conta de sua perda na forma de $\mathrm{CH}_{4} \mathrm{e} \mathrm{CO}_{2}$ ) e alto teor de fósforo. Seu grau avançado de decomposição faz com que o solo absorva com maior facilidade os nutrientes.

Diversas pesquisas (PRESTON e RODRIGUEZ, 2002; RODRIGUEZ et al., 1998; MOOG et al., 1997) mostram os benefícios da utilização do efluente em substituição a fertilizantes químicos na produção de mandioca (cassava), espinafre, plantas aquáticas, entre outros.

\subsection{Escalas de Aproveitamento do Biogás}

Segundo Moser (1997), o planejamento para operação de uma planta de biogás deve ser desenvolvido para determinar os possíveis usos finais da máxima produção de biogás. Para isso é necessário determinar a quantidade e qualidade dos resíduos orgânicos a serem gerenciados, que por sua vez dependem do número e tipo de animais, assim como de seu regime de criação e alimentação.

Na maioria dos casos o biogás simplesmente substitui a queima direta de algum outro combustível convencional (derivados do petróleo, lenha, entre outros), porém a produção de eletricidade envolve outros cenários interessantes.

Em função do exposto anteriormente, nos itens a seguir são consideradas duas escalas de aproveitamento: em pequenas propriedades familiares e em médias e grandes propriedades.

\subsubsection{Utilização do Biogás em Pequenas Propriedades Familiares}

A difusão da tecnologia do biogás em pequena escala, tem-se destacado como uma das maiores tentativas para difundir a tecnologia nas áreas rurais nos países em desenvolvimento. Gustavsson (2000) estima que o investimento inicial para a instalação de um biodigestor familiar de baixo custo é pelo menos igual ao requerido para comprar um botijão de GLP. 
Para validar a adoção da tecnologia do biogás é necessário avaliar o número de cabeças de gado que o produtor possui (disponibilidade de esterco), geralmente associada com a quantidade de terra que cultiva. Para Gustavsson (2000), uma produção de 44 a $55 \mathrm{~kg} /$ dia de esterco bovino úmido ou 48 a $60 \mathrm{~kg} /$ dia de esterco de búfalos é adequada para uma propriedade familiar.

Nas pequenas propriedades familiares, o principal benefício da utilização do biogás é a substituição do querosene e da lenha, principalmente, por meio da combustão direta para cocção e iluminação (MOOG et al. 1997; RODRIGUEZ et al. 1998).

Rodriguez et al. (1998) também afirmam que as atividades agrícolas e pecuárias podem ser integradas para aproveitamento conjunto do biogás e do efluente. Dessa forma, o biogás é usado basicamente para o cozimento de alimentos e o efluente como fertilizante de cultivos (mandioca, plantas forrageiras, entre outras) e como fonte de nitrogênio para plantas aquáticas. Esses cultivos, por sua vez, incluindo as folhas da mandioca, são aproveitados como alimento para os animais do sistema (farming system), como mostrado na Fig. 3.6.

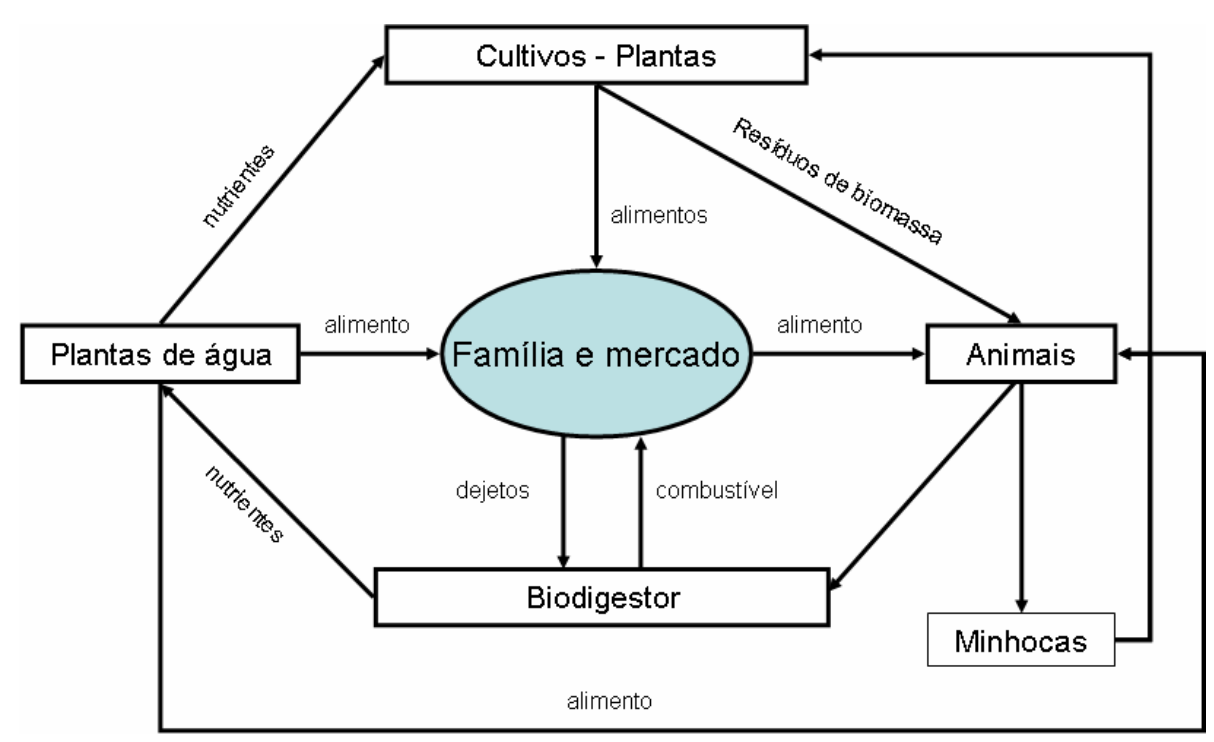

Figura 3.6. Integração da DA em sistemas agropecuários.

Fonte: Preston e Rodriguez (1996) 
Em países como Colômbia, Etiópia, Tanzânia, Vietnã e Camboja o biodigestor de baixo custo vem sendo utilizado para atender as necessidades de pequenos produtores, por conta de sua construção estar baseada em materiais já disponíveis nos locais, simplificando, as tarefas de instalação, operação e manutenção (RODRIGUEZ et al., 1998).

O preço de um biodigestor de concreto instalado para uma família média no Vietnã, segundo An (1997), variava de US\$ 180,00 a 340,00/m². Os chineses tentaram diminuir esse custo para US $\$ 25,00$ a $30,00 / \mathrm{m}^{3}$ com os biodigestores redmud, mas esse valor ainda é alto quando comparado com os biodigestores de polietileno (US $\left.\$ 5,00 / \mathrm{m}^{3}\right)$.

Com a finalidade de viabilizar esse tipo de empreendimento, diversos tipos de biodigestores devem ser testados para avaliar os custos e os impactos de sua instalação em diversos locais (regiões), para incentivar a utilização do biogás como suporte da economia familiar (SINGH e SOOCH, 2004).

Além dos benefícios econômicos, do uso de biodigestores de baixo custo em pequenas propriedades sem acesso ou acesso limitado a combustíveis comerciais, o abastecimento de energia pode ser descentralizado. Além disso, benefícios sociais podem ser atingidos, por meio da geração de emprego, estimulando, com isso, o desenvolvimento rural, diminuindo o êxodo às grandes cidades.

Dentre os grandes empecilhos para uma maior difusão de uso do biogás, destacam-se a falta de recursos econômicos para a compra e instalação dos equipamentos necessários e a falta de conhecimento técnico dos proprietários.

Em países como Vietnã, Tanzânia e Filipinas, onde foram implantados programas para introduzir os biodigestores de plástico de baixo custo em fazendas leiteiras de pequena escala (Fig. 3.7), foram relatados problemas como danos no plástico por ação do sol ou perfurações acidentais (por animais, pessoas, condições climáticas), falta de financiamento, problemas técnicos e preparação técnica ineficiente (ESQUIVEL et al., 2002). 


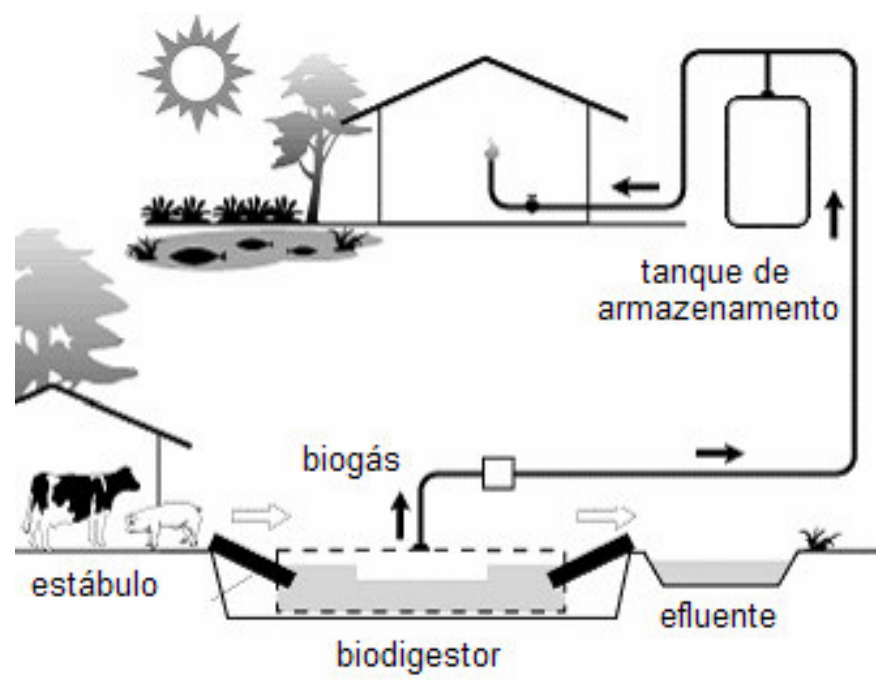

Figura 3.7. Biodigestor familiar

Fonte: An (1997)

Khang e Tuan (2002) estimaram que o custo (operação e capital) de um biodigestor plástico de baixo custo de $10 \mathrm{~m}^{3}$ de capacidade é de US\$100,00 e com uma taxa de juros de $6 \%$, o tempo de retorno seria de 1,5 anos, para um custo equivalente ao gasto mensal para compra de gás para cozinha (US\$6,00/mês).

Na Índia, Jash e Basu (1999) desenvolveram um mini-digestor para iluminação de residências rurais por quatro horas, substituindo a popular lâmpada a querosene, construído com materiais locais de baixo custo (argila, tijolo, entre outros) e para operar com os resíduos de dois bovinos (cerca de $12 \mathrm{~kg}$ de esterco por dia) que por sua vez apresentam uma produção diária de $0,5 \mathrm{~m}^{3}$ de biogás.

Esses autores afirmam ainda que para operar um biodigestor modelo indiano de $2 \mathrm{~m}^{3}$ são requeridos de 6 a 8 animais. Aproximadamente de 3 a $4 \%$ da população rural, que por sua vez representa $60 \%$ da população total da Índia, tem gado suficiente para isso. A maioria conta com 2 a 3 cabeças de gado.

Por outro lado, Rubab e Kandpal (1996) afirmam que assumindo uma produção de $0,04 \mathrm{~m}^{3} / \mathrm{kg}$ de esterco bovino e uma eficiência de coleção de $75 \%$, na maioria de 
estados da Índia seria necessário os resíduos de 3 cabeças de gado para a instalação de um biodigestor de $1,0 \mathrm{~m}^{3}$.

\subsubsection{Utilização do Biogás em Médias e Grandes Propriedades}

Em fazendas leiteiras de médio e grande porte, além das demandas básicas listadas anteriormente, existem outras demandas por energia na forma de calor/frio ou eletricidade. São exemplos a demanda por água quente para a limpeza dos equipamentos que manejam o leite, por geração de frio para resfriamento do leite, e a energia elétrica para acionamento de sistemas de ordenha, iluminação, entre outros. O biogás pode ser utilizado como combustível em sistemas de cogeração e satisfazer a maioria dessas demandas energéticas (Fig. 3.8).

Para se ter uma idéia dessas demandas, o resfriamento de leite geralmente requer de 100 a $120 \mathrm{MJ}$ de energia elétrica por tonelada de produto, incluindo o processo de bombeamento do leite e da água para lavar os recipientes e equipamentos (RIVA, 1992). Os relatórios do programa AgSTAR indicam que o préresfriamento do leite produzido por uma vaca só requer $15 \%$ do potencial de geração de biogás dessa mesma vaca (MEARS, 2001).

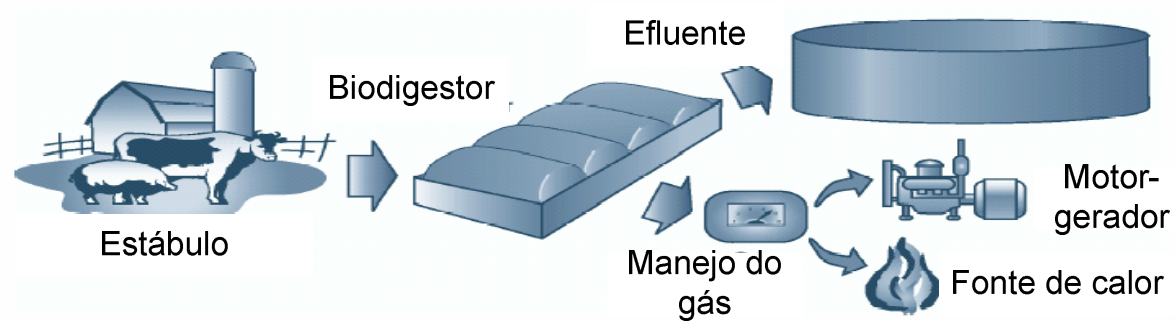

Figura 3.8. Componentes e produtos de um sistema de recuperação de biogás

Fonte: AgSTAR (2002) 
Para suprir a eletricidade necessária nas atividades da fazenda leiteira em áreas isoladas da rede, normalmente são usados grupos geradores acionados por motores de combustão interna, de ciclo Otto e ciclo Diesel, ambos disponíveis nessa área, especialmente o motor a diesel. Esses motores apresentam a versatilidade de serem modificados para operarem com substituição parcial ou total de biogás, uma alternativa técnica e até economicamente interessante desde que os próprios recursos da fazenda sejam utilizados.

A fazenda leiteira de grande escala, que incorpora princípios de ecologia industrial, tentando melhorar a eficiência e desenvolvimento sustentável de um sistema, otimizando o uso da energia e materiais enquanto são minimizados os resíduos e os poluentes, é considerada por Zicari (2003) como um Sistema de Energia Integrado (Integrated Farm Energy - IFE, Fig. 3.9).

A energia gerada dentro desses sistemas pode ser usada in loco para atender total ou parcialmente às necessidades de eletricidade, calefação, resfriamento, entre outros, e/ou vendida à vizinhança ou rede pública de distribuição de energia, conforme a configuração escolhida para o aproveitamento do potencial combustível do biogás. Conseqüentemente, a dependência de fontes externas de energia pode ser minimizada/eliminada e a receita incrementada. 


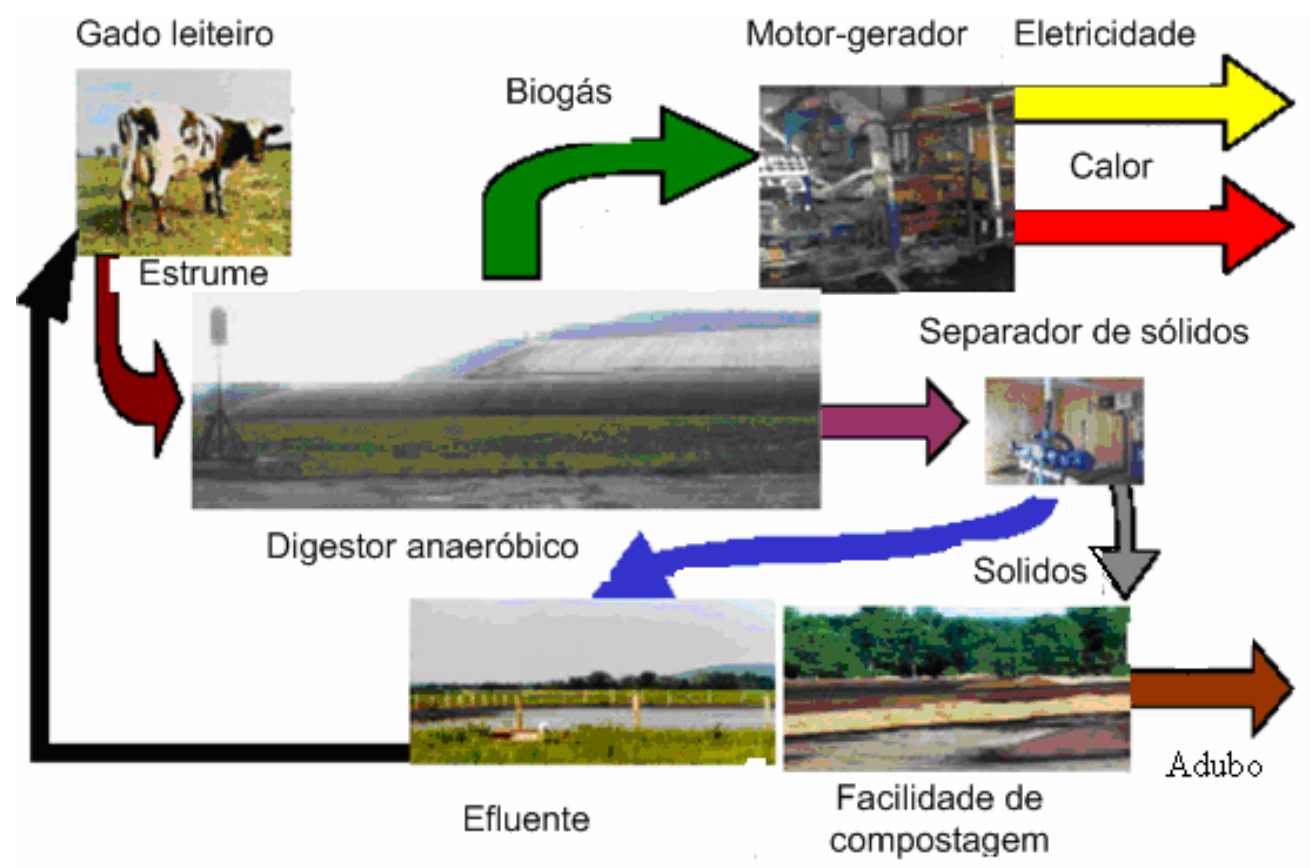

Figura 3.9. Sistema de Energia Integrado numa fazenda leiteira

Fonte: Zicari (2003)

Segundo Zicari (2003), com a utilização do biogás uma fazenda leiteira com 300 vacas pode economizar pelo menos US\$2.000,00/ano, enquanto que para uma fazenda com 1.000 cabeças essa economia pode chegar a US\$ 7.000,00/ano. Ainda segundo esse autor, um estudo realizado nos EUA mostrou que se todo o esterco do estado de New York fosse coletado, processado usando digestão anaeróbica e utilizado para geração de energia por grupos geradores acionados por motor de combustão interna, seriam produzidos anualmente $280 \mathrm{GWh}$, suficiente para cobrir a demanda elétrica de cerca de 47.000 casas, além das necessidades das próprias fazendas.

Soares et al. (2005) estimaram, baseados numa exploração hipotética de 115 bovinos (80 vacas leiteiras e outros), uma produção diária de $4.500 \mathrm{~kg}$ de resíduos, $173,9 \mathrm{~m}^{3}$ de biogás para operar um motor de $11 \mathrm{~kW}$. Determinou-se que os gastos envolvidos na instalação, €83.163,00 (sendo $49 \%$ correspondente às instalações do biodigestor e $51 \%$ ao sistema de geração de energia), conseguiriam abater só $66 \%$ da 
fatura energética anual da propriedade (redução de $€ 23.874,00$ ), e com isso o tempo de retorno do investimento (TRI) seria superior em 4,3 anos aos 10 anos estabelecidos como horizonte de vida da instalação. Os autores estimaram ainda que a instalação seria economicamente viável se o número de vacas leiteiras fosse superior às 525 (TRI $=7$ anos).

Portanto a viabilização econômica de um sistema de produção e valorização de biogás é condicionado pelas características da exploração, o número de animais, tipo de estabulação e regime de limpeza do estábulo, influenciam nas características dos substratos que são confinados no biodigestor. Segundo Burke (2001), nos EUA o custo de investimento de um sistema de digestão, processamento de sólidos e geração de energia é de aproximadamente US\$500,00 a 800,00 por vaca. 


\section{SISTEMAS DE GERAÇÃO DE ENERGIA E DE RESFRIAMENTO DE LEITE}

\subsection{Introdução}

Nas áreas rurais mais afastadas, em países em desenvolvimento, a dificuldade de acesso a recursos energéticos comerciais, principalmente a energia elétrica, é um fator que limita as pequenas atividades agroindustriais. Normalmente, por estarem no final das linhas de transmissão, as propriedades rurais arcam com elevados custos de instalação e recebem uma energia de baixa qualidade, sujeita a muitas variações de tensão e interrupções de fornecimento.

Assim, como mencionado no capítulo anterior, sistemas de geração de energia capazes de aproveitar os recursos disponíveis no setor rural (como o biogás) caracterizam uma alternativa interessante para o atendimento da própria demanda de energia e a venda dos excedentes às propriedades vizinhas (ou à própria rede, quando isso é possível).

Na figura 4.1 é descrito qual o possível uso do biogás para o atendimento do resfriamento do leite na fazenda leiteira. Dessa forma é destacada a importância do gerenciamento adequado do esterco.

Dentre os sistemas de geração de energia, uma configuração interessante para pequenos e médios produtores é a utilização de motores de combustão interna, operados com biogás, acoplados a geradores para suprir a demanda de energia elétrica na fazenda. Diversas pesquisas foram desenvolvidas na década de 70 e 80, e atualmente esse interesse vem sendo retomado. 


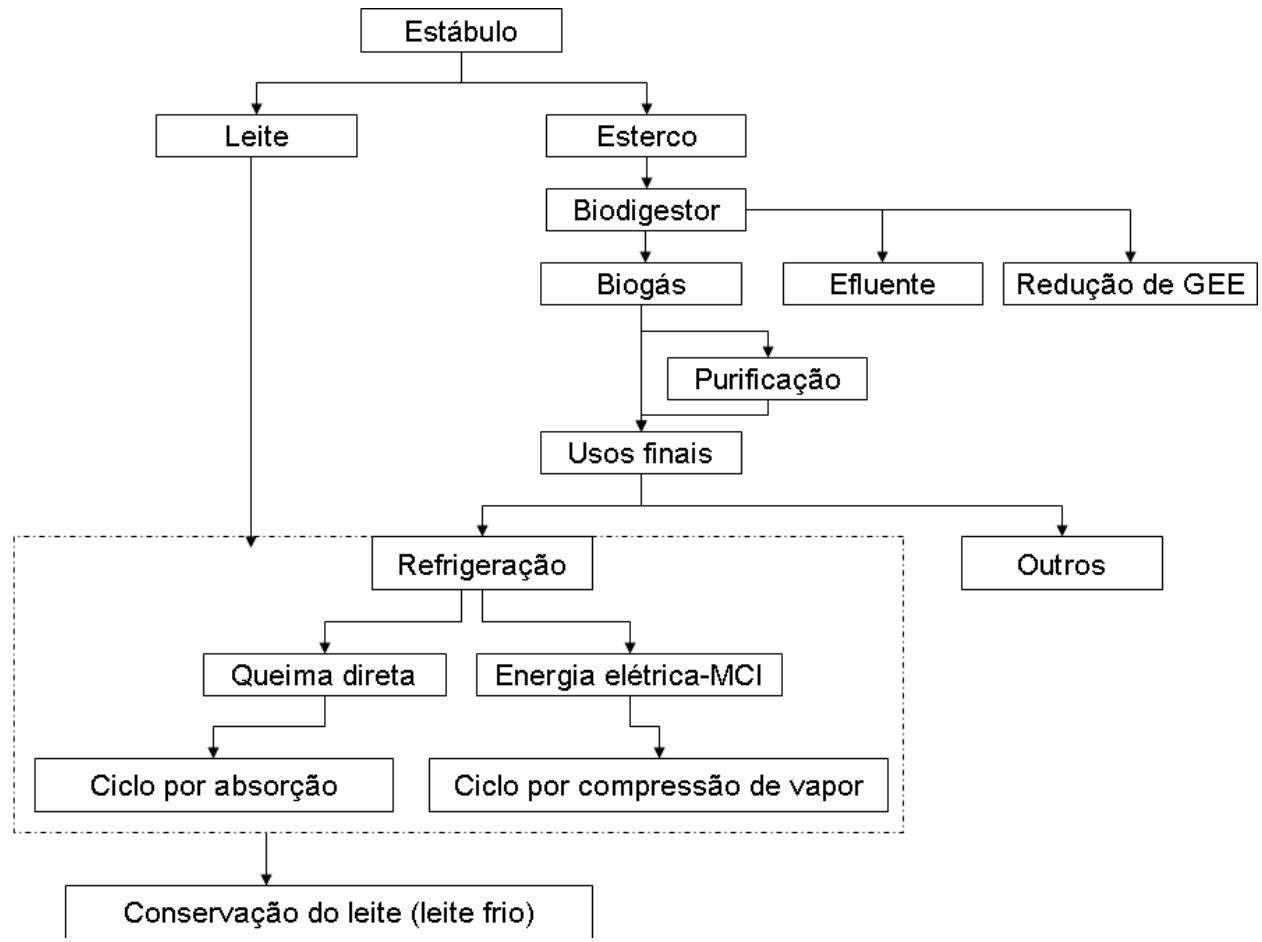

Figura 4.1. Uso do biogás no resfriamento do leite na fazenda leiteira

\subsection{Motor de Combustão Interna (MCI)}

Nos últimos anos, as pesquisas em energia têm sido orientadas, principalmente, no desenvolvimento de sistemas mais eficientes, na redução dos níveis de emissão de poluentes e no desenvolvimento de combustíveis alternativos, em função da competitividade, da legislação restritiva de emissões cada vez mais rigorosa e da decrescente disponibilidade de combustíveis, respectivamente (ALEGRE, 1993).

Quando avaliadas as necessidades de energia do setor rural, o MCI pode ser considerado como uma excelente alternativa para a implantação de um sistema de geração de energia, pelo fato de já existir uma cultura de utilização e por poderem ser facilmente adaptados para operação com combustíveis alternativos em distintos processos e sob diversos regimes de operação. O motor a diesel tem concentrado 
maior interesse, uma vez que são mais resistentes e mais comuns no setor rural (CAVIDAD, 1998).

Um aspecto interessante na utilização de MCI é a sua versatilidade em operar, além dos combustíveis convencionais (gasolina e diesel), outros combustíveis alternativos fósseis como o gás natural (GN) e gás liquefeito de petróleo (GLP), bem como combustíveis renováveis como o biogás, o álcool e o biodiesel, ou mesmo com misturas de diferentes combustíveis. Um exemplo típico dessa versatilidade é a recente popularização, no Brasil, dos veículos automotivos bi ou multi-combustíveis (tecnologia "flex-fuel").

O biogás pode ser utilizado diretamente do biodigestor em motores estacionários e assim auxiliar no suprimento de energia em regiões remotas. Para unidades móveis, a purificação e o armazenamento são requeridos, o que condiciona sua viabilidade. Silva (1995) indica que motores a álcool, de grande disponibilidade no mercado brasileiro e, por apresentarem uma razão de compressão mais elevada, os torna interessantes para serem operados com biogás.

Segundo o Catálogo Metano Automotivo RODAGÁS (1984 apud SILVA, 1995), o sistema de alimentação de motores com metano, quer para o ciclo Otto ou Diesel, está composto basicamente pelos mesmos equipamentos: reservatório de metano, válvula redutora de pressão e misturador de ar e gás. Para um motor estacionário, alimentado com biogás, o sistema de alimentação precisaria só do misturador, uma vez que o digestor faz às vezes de reservatório e a pressão do gás já está em níveis adequados para sua utilização (alimentação do motor).

Diversos estudos têm avaliado o comportamento do MCI quando o combustível original (gasolina, diesel) é substituído parcial ou totalmente por biogás (CAVIDAD, 1998; MOUSTAFA et al., 1991; MITZLAFF, 1988; WERNER et al., 1989, entre outros), outros têm avaliado uma mistura de $\mathrm{CO}_{2}$ e $\mathrm{CH}_{4}$ (ou gás natural) para simular o comportamento do biogás (EMBRATER, 1984; HENHAM e MAKKAR, 1998; BARI, 1996; JAWUREK e RALLIS, 1984; JAWUREK et al., 1987). Esses estudos mostraram que a qualidade do biogás afeta a operação e, portanto, o rendimento do MCI. 
Jawurek e Rallis (1984) avaliaram o comportamento da substituição total de gasolina por biogás em moto-geradores em aplicações rurais de pequena escala (menores que $10 \mathrm{~kW}$ ), determinando que a eficiência energética era maior que quando alimentado só com gasolina, e se registrou um aumento de 80 a $100^{\circ} \mathrm{C}$ na temperatura de trabalho e menor formação de carbono na câmara de combustão.

Quando considerado o acoplamento de um gerador em um motor, deve se levar em conta o tipo de transmissão de potência que será utilizado. Mitzlaff (1988) indica que quando a transmissão é direta, a perda de potência pode ser desconsiderada. Quando utilizado um sistema de polias, a perda de potência varia entre 3 e $8 \%$ para correias em V e entre 10 e $20 \%$ para correias planas. Assim mesmo, alguns autores (WALSH et al., 1988; JEWELL et al., 1986) sugerem que a unidade não deve operar a menos de $60 \%$ da potência máxima.

Para produtores de leite de pequena escala, a micro-cogeração constitui uma alternativa mais atrativa, devido à possibilidade de recuperação e aproveitamento de distintas formas de energia, capazes de justificar o investimento. Esse sistema pode ser aproveitado para gerar energia elétrica (quando associado com geradores) e/ou trabalho de eixo para acionamento de equipamentos como compressores, além de permitir a recuperação de calor dos gases de escape, da água de resfriamento e do óleo lubrificante.

Além disso, sistemas de cogeração com MCI podem ser associados com equipamentos de refrigeração e/ou bombas de calor por absorção, uma vez que estes necessitam de uma fonte de calor na faixa de 80 a $200^{\circ} \mathrm{C}$, temperaturas típicas obtidas na recuperação de calor em MCI's.

\subsubsection{Substituição Total de Gasolina por Biogás em MCI de Ciclo Otto}

Por conta do menor conteúdo energético, o biogás apresenta uma menor velocidade de combustão. Portanto, para facilitar a ignição, recomenda-se a admissão de misturas pobres próximas da estequiométrica, bem como um avanço no sistema de ignição. Misturas mais pobres, permitem a utilização de taxas de compressão mais 
elevadas e evitam a auto-ignição, porém prejudicam o início da combustão (SILVA, 1995).

Segundo Walsh et al. (1988), a modificação do motor, envolve:

- Carburação, que consiste em incrementar a capacidade de entrada de combustível e restringir a entrada de ar de combustão;

- Centelha de ignição mediante a regulagem da abertura das velas (entre 0,4318 e $0,76 \mathrm{~mm})$

- Avanço da centelha, devido à baixa velocidade de chama dos combustíveis gasosos como o biogás;

- Aprimoramento no serviço de manutenção.

Para o cálculo da relação ar-combustível, considera-se que para a combustão completa de $1 \mathrm{~m}^{3}$ de metano são requeridos $9,52 \mathrm{~m}^{3}$ de ar. Já para $1 \mathrm{~m}^{3}$ de biogás com $65 \%$ de metano e $35 \%$ de $\mathrm{CO}_{2}$, serão requeridos $6,19 \mathrm{~m}^{3}$ de ar. A equação de combustão completa para $1 \mathrm{~m}^{3}$ de biogás é dada por:

$$
0,65 \mathrm{CH}_{4}+0,35 \mathrm{CO}_{2}+1,3\left(\mathrm{O} 2+3,76 \mathrm{~N}_{2}\right) \rightarrow 1 \mathrm{CO}_{2}+1,3 \mathrm{H}_{2} \mathrm{O}+4,89 \mathrm{~N}_{2}
$$

Com finalidade de obter uma eficiência adequada, Jewell et al. (1986) indicam que a combustão do biogás deve ocorrer com excesso de ar, com uma razão de equivalência $(\Phi)$, definida pela Eq. (4.1), que deve flutuar entre 0,8 e 0,9.

$$
\mathrm{AC}_{\mathrm{ef}}=\frac{\mathrm{AC}_{\mathrm{stq}}}{\Phi}
$$


$\mathrm{Na}$ equação anterior $\mathrm{AC}_{\text {stq }}$ é a relação ar-combustível estequiométrica e $\mathrm{AC}_{\mathrm{ef}}$ a relação efetiva. Conforme o valor de $\Phi$ tem-se:

$$
\begin{aligned}
& \Phi=1 \text { : relação estequiométrica } \\
& \Phi<1 \text { : excesso de ar } \\
& \Phi>1 \text { : excesso de combustível }
\end{aligned}
$$

Jewell et al. (1986) afirmam que na substituição da gasolina pelo biogás, é registrada uma queda de 15 a 20\% na máxima potência do motor de uso automotivo, por conta de não ter sido projetado para operar com combustíveis gasosos. Por outro lado, no acionamento de motores estacionários movidos a biogás, em diversos trabalhos (WALSH et al., 1988, JEWELL et al., 1986, WERNER et al., 1989) essa queda geralmente não é registrada.

Para a determinação do consumo de biogás, incluindo uma possível perda de potência no motor, podem ser utilizadas as seguintes equações:

$$
\begin{gathered}
\dot{\mathrm{m}}_{\text {biogás }}=\mathrm{FC}_{\text {biogás }} \times(1-\mathrm{FPP}) \times \dot{\mathrm{W}}_{\text {motor }} \\
\mathrm{FC}_{\text {biogás }}=\frac{\mathrm{FC}_{\text {gasolina }} \cdot \mathrm{PCI}_{\text {gasolina }}}{\mathrm{PCI}_{\text {biogás }}}
\end{gathered}
$$

Onde $\mathrm{W}_{\text {motor }}$ é a potência do motor, FPP o fator de perda de potência e $\mathrm{FC}_{\text {biogás }}$ o fator de consumo de biogás, $\mathrm{PCI}_{\text {biogás }}$ e $\mathrm{PCI}_{\text {gasolina }}$ são o poder calorífico inferior do biogás e da gasolina, e $\mathrm{FC}_{\text {gasolina }} \mathrm{o}$ fator de consumo de gasolina.

Werner et al. (1989) consideram que esse $\mathrm{FC}_{\text {biogás }}$ seja de 0,5 a $0,8 \mathrm{~m}^{3} / \mathrm{kWh}$. Piccinini et al. (1996), por sua vez consideram que para operar um motor de $15 \mathrm{~kW}$ alimentado por biogás (65\% de metano), é requerido $0,58 \mathrm{~m}^{3} / \mathrm{kWh}$. 
A vazão de ar de combustão requerido pode ser determinada a partir do fator de consumo de biogás e da relação estequiométrica. Dessa forma obtém-se, segundo a Eq. 4.4, o fator de admissão de ar ( $\left.\mathrm{FA}_{\mathrm{ar}}\right)$.

$$
\mathrm{FA}_{\mathrm{ar}}=\left(\frac{\mathrm{AC}_{\mathrm{stq}}}{\Phi}\right) \times \mathrm{FC}_{\text {biogás }}
$$

É importante destacar que o consumo específico de combustível por unidade de energia mecânica produzida depende da qualidade, temperatura e pressão do biogás, assim como da própria eficiência e ponto de operação do motor. Assim, deve ser acertado o tempo de ignição e a mistura combustível adequada e a filtragem do $\mathrm{H}_{2} \mathrm{~S}$ presente no biogás, considerada. Por outro lado, se o conteúdo de $\mathrm{CO}_{2}$ superar em 3 vezes o conteúdo de metano no biogás, não haverá combustão.

\subsubsection{Substituição Parcial de Diesel por Biogás em MCI de Ciclo Diesel}

As primeiras aplicações comerciais da substituição parcial de combustíveis fósseis convencionais por combustíveis alternativos como GN e biogás em MCI datam de 1935. Na Segunda Guerra Mundial, por exemplo, já eram utilizadas misturas de gás de carvão, biogás, metano e gasolina de baixa qualidade em forma de vapor gaseificado.

No setor agropecuário, tem sido dada preferência para motores diesel operando com uma mistura de biogás de 10 a 20\% de combustível diesel (porcentagem mínima necessária para manter a ignição), por conta de sua alta disponibilidade. Essa porcentagem varia com o ponto de operação e os parâmetros do motor (HENHAM e MAKKAR, 1998). Segundo Fulford (1984), na Índia essas configurações já estavam comercialmente disponíveis na época.

Para operar um motor a diesel com a mistura do combustível diesel-biogás são necessárias apenas modificações simples no sistema de alimentação com a flexibilidade de voltar a operar só com diesel em casos de queda no fornecimento de 
biogás, isso sem alterar o funcionamento (BARI, 1996). Por outro lado, Jawurek et al. (1987) afirmam que esses motores a diesel, principalmente os pequenos de alta rotação e sujeitos a carga variável, requerem complexas modificações. Riva (1992) recomenda que os motores operem na faixa de 1000 a $1500 \mathrm{rpm}$ e com sistema de arrefecimento por água a fim de permitir a recuperação do calor.

Como desvantagens podem ser apontadas a dependência de dois combustíveis, o difícil controle sobre a alimentação desses e a provável redução da vida útil dos bicos injetores por causa do superaquecimento.

Silva (1995) indica que tal superaquecimento pode ser reduzido com substituições inferiores a $70-80 \%$ do diesel. Esse autor também afirma que o controle da alimentação de combustíveis de diferentes características termodinâmicas (um líquido e outro gasoso), é difícil e do seu aprimoramento depende o melhor desempenho do motor.

Por outro lado, Mitzlaff (1988) sinaliza que tal controle pode ser executado sobre a alimentação do gás combustível, promovendo a formação de misturas pobres com a consequiente queda na temperatura por conta da baixa liberação de calor. Porém, misturas muito pobres (taxa de excesso de ar, $\lambda>4,0$ ), podem comprometer a combustão. Ainda, o autor, indica que o sistema carburador deve garantir uma mistura homogênea, variar o fluxo conforme a carga do motor e promover uma taxa de excesso de ar $\lambda=1,5(\Phi=0,7)$, considerando a necessidade de ar para a combustão do diesel piloto.

Para Silva (1995), uma câmara de mistura simples pode resultar da conexão de um tubo de suprimento de gás combustível na câmara do filtro de ar do motor. A depressão própria da admissão de ar no motor facilita a descarga do gás que ainda pode ser controlada por uma válvula. Tal mistura ar/gás possibilitará que o motor opere bem em determinado regime estável de rotação e carga, portanto adequado para unidades estacionárias que não demandam potência variável.

No trabalho desenvolvido por Silva (1995), determinou-se que o avanço do ponto de injeção, embora permita um funcionamento mais estável de unidades com 
estreito regime de rotação de trabalho, como o trator agrícola ou motores estacionários, não limita a operação com duplo combustível. Essas unidades não dispõem de avanço centrífugo na bomba injetora. Além disso, a economia de combustível em motores a duplo combustível será maior quanto maior for a potência de operação (carga).

Em um motor Diesel a duplo combustível, uma maior potência pode ser obtida, porém com redução na eficiência térmica e incremento da temperatura de exaustão. Essas temperaturas, segundo Mitzlaff (1988), podem variar entre 500 e $700^{\circ} \mathrm{C}$ para um motor a duplo combustível e entre 400 a $600{ }^{\circ} \mathrm{C}$ para operação com $100 \%$ de diesel.

Outros estudos sobre a substituição parcial do diesel com biogás têm concluído que menores rendimentos estão associados tanto com maiores concentrações de $\mathrm{CO}_{2}$ quanto com maiores substituições de diesel. Segundo Henham e Makkar (1998), para substituições acima de $60 \%$ do diesel, o motor começa a fazer barulho, e a temperatura dos gases de escape e a emissão de $\mathrm{CO}$ são mais afetadas pela substituição do diesel que pela qualidade do biogás.

No estudo realizado por Bari (1996) sobre o efeito do $\mathrm{CO}_{2}$ no desempenho de um motor bi-combustível diesel-biogás, conclui-se que o rendimento do motor não varia muito com conteúdo abaixo de $30 \%$ de $\mathrm{CO}_{2}$ no biogás, e nem precisa de lavagem (scrubbing). O conteúdo acima de $45 \%$ origina um funcionamento "áspero" do motor.

Por outro lado, Moustafa et al. (1991) avaliaram o comportamento de um MCI de $5 \mathrm{HP}$ alimentado com diesel e com mistura diesel-biogás $\left(\mathrm{CH}_{4}=68 \%\right.$ e $\mathrm{CO}_{2}=$ $30 \% ; \mathrm{PCI}=22.540 \mathrm{~kJ} / \mathrm{m}^{3}$ ). A eficiência térmica a $75 \%$ de carga passa de $18 \%$ (só diesel) para $16 \%$ quando alimentado com mistura, em função do baixo PCI do biogás e da menor velocidade de chama. Adicionalmente, determinou-se que a operação do MCI com 45\% de substituição de diesel, segundo a capacidade de geração de biogás do biodigestor, seria de $1 \mathrm{~h}$ para uma potência elétrica de 1.650 Watts (melhor eficiência). 


\subsubsection{Manutenção de motores com substituição parcial ou total de biogás}

Embora um MCI seja projetado para operar por longo tempo (aproximadamente 20.000 horas), certos procedimentos de manutenção programada e preventiva devem ser seguidos para assegurar a longevidade do motor, pois o uso do biogás (combustível não padrão) afeta o ciclo de substituição de componentes. Para o uso de biogás, esse ciclo é encurtado, reduzindo-se assim os intervalos de troca de óleo e filtro (manutenção programada) e outros componentes como , assim como velas, juntas, anéis de pistão, componentes eletrônicos, etc. (manutenção preventiva).

Os custos de manutenção variam com o tipo, velocidade, tamanho e número de cilindros do motor. Esses custos estão tipicamente associados com mão de obra e peças, e são diretamente proporcionais à concentração de $\mathrm{H}_{2} \mathrm{~S}$ no gás alimentado, o qual deve ser removido se sua concentração superar os 1000 ppm (CHAMBERS e POTTERS, 2002).

A troca de óleo representa a principal atividade que deve ser levada em conta no aprimoramento do serviço de manutenção de motores alternativos que usam biogás. Diversos autores (WALSH et al., 1988; JEWELL et al., 1986; MITZLAFF, 1988) recomendam que seja efetuada entre 300 a 600 horas de operação, devendo ser utilizados óleos com $\mathrm{TBN}^{4}$ (número de base total) entre 4 e 8 para prevenir a condensação do vapor de água e do $\mathrm{H}_{2} \mathrm{~S}$ no óleo. Recomenda-se ainda manter a temperatura do óleo acima de $88^{\circ} \mathrm{C}$.

\subsection{Sistemas de Resfriamento de Leite}

Nas fazendas leiteiras, para o resfriamento e armazenagem de leite cru, diversos sistemas são utilizados. Os sistemas mais simples usam água de um cano ou poço, nos que o leite chega alcançar de 3 a $5{ }^{\circ} \mathrm{C}$ acima da temperatura da água.

\footnotetext{
${ }^{4}$ TBN (total base number): capacidade do óleo lubrificante neutralizar a formação de ácidos.
} 
Quando houver bastante água de poço, os latões de leite podem ser imersos dentro do poço. Considerando-se o fato de que esta temperatura ainda é alta, para melhor conservar o leite na fazenda são necessárias unidades de resfriamento artificial (equipamentos especializados).

Dentre essas unidades, normalmente são utilizados sistemas de refrigeração por compressão mecânica de vapor, devido à simplicidade da instalação, rapidez de resfriamento e alto rendimento. Porém, a falta de redes de distribuição de energia elétrica, muitas vezes, limita a sua instalação. Assim, sistemas de refrigeração por absorção poderiam se adaptar melhor às condições rurais, uma vez que aproveitariam fontes de energia não convencionais como o biogás.

Uma análise comparativa entre o ciclo de refrigeração por absorção e por compressão de vapor (Fig. 4.2) evidencia que o evaporador, o condensador e o dispositivo de expansão são componentes comuns aos dois tipos de ciclo. Em ambos os sistemas o calor do leite é transferido para o meio de resfriamento (portador frigorífico). Esta transferência ocorre através de uma parede de separação, sem contato direto do leite com o meio de resfriamento.

Esse meio de resfriamento absorve o calor do leite no evaporador $\left(\mathrm{Q}_{\mathrm{ev}}\right)$. Seguidamente, em um processo de compressão o vapor refrigerante é levado para o condensador, dispositivo onde o líquido evaporado é condensado, por meio da cessão de calor para a circunvizinhança (transferência de calor com água ou ar, $\mathrm{Q}_{\mathrm{cd}}$ ). Posteriormente, o refrigerante líquido sofre um processo de expansão (válvula de expansão) em que o refrigerante retoma suas características intrínsecas e ingressa no evaporador para recomeçar o ciclo.

A diferença básica entre esses ciclos está na forma de se elevar a pressão do fluido refrigerante, e conseqüentemente no insumo energético necessário para tanto. Em um sistema por compressão de vapor a elevação da pressão deste, oriundo do evaporador é obtida por meio de um processo de compressão mecânica que por sua vez requer trabalho de eixo, normalmente fornecido por conversão eletromecânica no motor elétrico de acionamento do compressor ou pela queima de um combustível em um motor de combustão. 
Já em um sistema por absorção o vapor que deixa o evaporador é absorvido por uma mistura líquida de refrigerante mais um absorvente (processo que demanda cessão de calor desde o absorvedor para a circunvizinhança, $\mathrm{Q}_{\mathrm{ab}}$ ). A elevação de pressão pode ser realizada por uma bomba (requer energia mecânica ou elétrica para seu acionamento, $\mathrm{W}_{\mathrm{b}}$ ) ou um sistema de termosifão, que leva esse líquido para um gerador onde, por meio de uma fonte de calor, o refrigerante (agora a alta pressão) é liberado da mistura e encaminhado para o condensador. Como o trabalho de bombeamento de líquido é muito menor (aproximadamente representa o 10\%) que o de compressão de um gás, na prática o insumo básico para a operação do ciclo é a fonte de calor no gerador $\left(\mathrm{Q}_{\mathrm{ge}}\right)$, vindo da queima de combustíveis fósseis ou renováveis, como o biogás).

Os sistemas atualmente em uso em fazendas leiteiras, em sua maioria, utilizam ciclos de refrigeração por compressão de vapor.

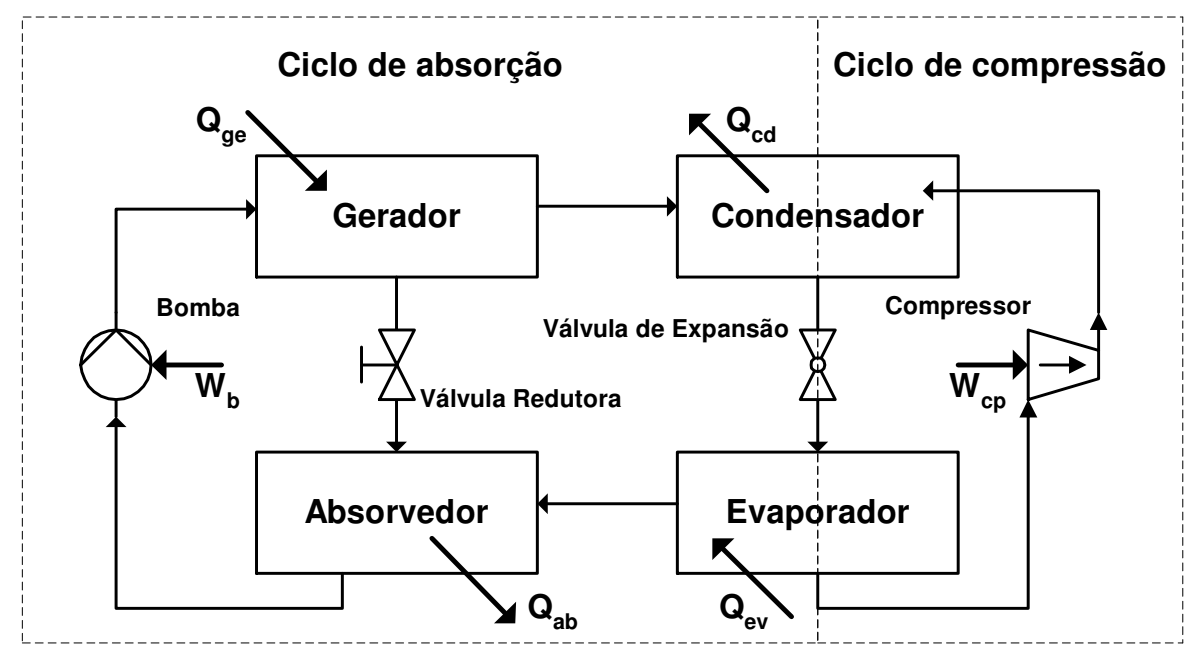

Figura 4.2. Comparação entre os ciclos por compressão de vapor e por absorção Fonte: Oliveira Jr. et al. (2004) 


\subsubsection{Tanque resfriador de leite}

O tanque de resfriamento de leite (Fig. 4.3) é uma unidade composta por um reservatório fabricado em aço inoxidável, cujo fundo é projetado como um evaporador, e um sistema de refrigeração (unidade condensadora), normalmente por compressão de vapor e com acionamento por motor elétrico. Adicionalmente, este equipamento conta com alguns outros componentes, dentre esses:

- um agitador, consistente em um moto-redutor acoplado a uma pá mecânica, encarregada da distribuição uniforme da gordura no leite e evitar a criação de crostas no processo de resfriamento (contato térmico);

- uma válvula de descarga de leite, por onde é realizado o bombeamento do leite ao caminhão-tanque coletor e a evacuação dos resíduos da lavagem;

- um sistema de controle de temperatura, que visa a manutenção da temperatura adequada de resfriamento.

Tanque de leite (reservatorio)

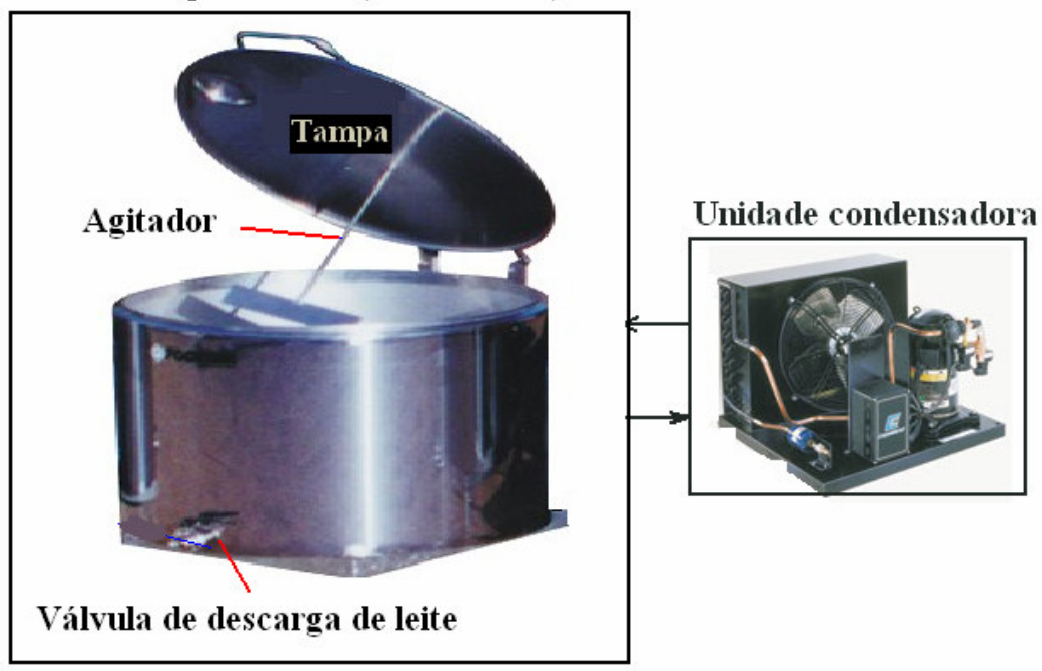

Figura 4.3. Tanque resfriador de leite

Fonte: DELAVAL (2005). 
As características de fabricação e operação destes equipamentos se encontram estipulados na legislação brasileira e descritas na Instrução Normativa 53 (IN53), cujos aspectos principais encontram-se no anexo B.

Nessa instrução, a designação de um tanque de resfriamento está caracterizada pelo número de ordenhas, a temperatura de operação e o tempo de resfriamento de leite. Por exemplo, o equipamento de resfriamento com o código 4BII destina-se a um tanque para quatro ordenhas, com capacidade resfriamento calculada a uma temperatura ambiente de $32{ }^{\circ} \mathrm{C}$ e um tempo de resfriamento menor a três horas para cada ordenha..

\subsubsection{Outros sistemas de resfriamento}

Como mencionado anteriormente, os tanques atualmente disponíveis no mercado utilizam unidades condensadoras por compressão mecânica de vapor, que requerem energia elétrica para seu acionamento. Essa energia elétrica, no setor agropecuário, pode não estar disponível em locais de difícil acesso, tornando necessária a utilização de geradores elétricos para suprir a demanda de energia.

Assim, os sistemas de refrigeração por absorção apresentam um grande potencial para adaptar-se às condições rurais, uma vez que podem aproveitar fontes de energia não convencionais, como o biogás. Miranda (2004), por exemplo, desenvolveu na Argentina o protótipo de um resfriador de leite para unidades produtivas de micro e pequena escala, capaz de operar com fontes de energia alternativa como o gás natural, biogás e energia solar, entre outras.

Já nos EUA, a Universidade da Geórgia, em parceria com o Ministério de Energia e Minerais e a Corporação do leite da Uganda comprovaram a viabilidade técnico-econômica de um sistema de refrigeração por absorção amônia-água, operado com biogás para o resfriamento de 3.500 litros de leite. Em uma segunda fase, o grupo de pesquisa vem trabalhando sobre pequenos volumes (50 a 100 litros) (KISAALITA, 2004). 
No Brasil, Abreu (1999) desenvolveu o protótipo de um sistema de refrigeração por absorção de calor de pequeno porte e baixo custo, para o aproveitamento de fonte de calor rejeitado e com isso suprir a demanda de localidades isoladas na faixa de 3 a $70,3 \mathrm{~kW}$ de potência frigorífica.

Por outro lado vêm sendo desenvolvidos sistemas baseados no aproveitamento da energia solar. A Food and Agricultural Organization (FAO), segundo Tuszynski, et al. (1983) tem promovido estudos desse tipo.

\subsection{Sistemas de Cogeração}

Por definição, a cogeração representa um meio alternativo e racional de gerar simultaneamente calor e energia eletromecânica a partir de uma única fonte de energia primária, para suprir as necessidades de uma unidade de processo, seja ela do setor industrial, terciário, agrícola ou um sistema isolado (BALESTIERI, 2002).

Para suprir a demanda de energia elétrica e de calor, um sistema convencional de geração de energia consome $41 \%$ a mais de energia primária que um sistema de cogeração. Além dos ganhos econômicos, o sistema de cogeração produz benefícios ambientais por quanto as reservas de energia não renováveis são preservadas e a poluição ambiental reduzida (MAIDMENT e PROSSER, 2000). Detalhadas análises econômicas e técnicas devem ser incluídas para a determinação da viabilidade.

A utilização de sistemas de cogeração para aplicações industriais e agroindustriais de grande porte (como usinas de açúcar e álcool), já é algo relativamente consolidado em termos conceituais e tecnológicos. Mais recentemente, os avanços tecnológicos estão permitindo que o campo de aplicação seja ampliado, caracterizando duas novas escalas de sistemas segundo a potência elétrica produzida. Plantas com até $200 \mathrm{~kW}$ são denominadas de pequenas e com menos de $100 \mathrm{~kW}$ de micro plantas (ALANNE e SAARI, 2004). Plantas com essas escalas permitem que também pequenas propriedades rurais e empresas no setor terciário, como restaurantes, edifícios comerciais, supermercados e hotéis, entre outros, utilizem esse tipo de sistema para suprir suas demandas de energia, aquecimento e resfriamento. 
Para essas pequenas escalas de geração, a configuração básica do sistema de cogeração é um equipamento para geração de energia elétrica a partir da queima de um combustível, com o posterior aproveitamento dos rejeitos térmicos para os processos de aquecimento e/ou resfriamento. Para o primeiro processo podem ser utilizados motores de combustão interna (MCI), assim como:

- micro-turbinas: são turbinas a gás com potência elétrica de 25 a $250 \mathrm{~kW}$, não são pesadas, são silenciosas, ocupam pouco espaço e operam a altas rotações; as elevadas temperaturas dos gases de exaustão favorecem a recuperação de calor e suas emissões são baixas. A baixa eficiência, especialmente em carga parcial, e o custo elevado são os principais entraves a uma maior utilização;

- motor Stirling: motor de combustão externa, onde o(s) pistão(ões) é(são) acionado(s) pela compressão e expansão de um gás de trabalho (hélio, hidrogênio), obtidas por meio do aquecimento e resfriamento cíclico do(s) cilindro(s). É silencioso e suas emissões são baixas (especialmente NOx). Devido à combustão externa, podem ser utilizados vários tipos de combustíveis, dentre esses, os alternativos sólidos, como a biomassa;

- células combustível: produzem eletricidade a partir de um processo eletroquímico de combinação de hidrogênio e oxigênio, com a intervenção de um ânodo, um cátodo e um eletrólito, produzindo água como subproduto. São silenciosas e de grande adaptabilidade à variação de carga. A disponibilidade de hidrogênio e o elevado custo de investimento (três vezes maior que um MCI) limitam seu uso. O hidrogênio pode ser obtido de vários combustíveis mediante processos de reforma.

Uma característica comum a todos esses equipamentos é a possibilidade de, além dos combustíveis convencionais (diesel, querosene, gasolina), utilizarem gás natural ou combustível alternativos como biomassa gaseificada, biogás, etc., tornando a cogeração, um empreendimento de menor impacto ao ambiente. Esses combustíveis são normalmente selecionados segundo o preço e a disponibilidade no local de consumo. 
Os sistemas de cogeração podem contribuir para a ampliação da capacidade instalada e/ou aumento da confiabilidade do sistema de transmissão. Assim a matriz energética se diversifica e as oportunidades de negócio para o capital privado crescem (RUCKER e BAZZO, 2004). A atratividade econômica de uma planta de cogeração será tanto maior quanto maior for o custo da energia primária substituída.

Segundo Maidment e Prosser (2000), pequenas unidades de cogeração foram recentemente desenvolvidas e vêm sendo utilizadas em novas aplicações com sucesso. Isto as converte no maior componente dentro da estratégia do governo do Reino Unido para reduzir as emissões de $\mathrm{CO}_{2}$. Para o ano de 2010, objetiva-se a instalação de $10 \mathrm{GW}$ baseados nessa tecnologia.

Na análise de Murphy et al. (2004), determinou-se que para uma planta CHP com uma eficiência elétrica de $35 \%$ e térmica de $40 \%$, consegue-se produzir 2,04 $\mathrm{kWh}$ de eletricidade e 2,33 kWh de calor para cada $\mathrm{m}^{3}$ de biogás (PCI de 21.000 $\mathrm{kJ} / \mathrm{m}^{3}$ ). Os rejeitos térmicos, nos sistemas de cogeração de micro e pequena escala, podem ser utilizados em sistemas de refrigeração por absorção (SRA). 


\section{O EFEITO ESTUFA E O SETOR AGROPECUÁRIO}

\subsection{Introdução}

Os seres humanos sempre influenciaram o meio ambiente, porém foi somente após o início da Revolução Industrial, em meados do século XVIII, que o impacto das atividades humanas tomou proporções globais.

A queima de combustíveis fósseis para o uso industrial e residencial, o rápido crescimento da população mundial, a agricultura mais extensiva e principalmente a queima da biomassa (desmatamento ou queimadas), produzem gases de efeito estufa que afetam a composição da atmosfera, o que por sua vez contribui para o aumento da temperatura média mundial, colocando em risco o equilíbrio ecológico e conseqüentemente a própria sobrevivência da espécie humana.

A necessidade por alimentos, que acompanha o gradativo crescimento da população mundial, tem contribuído enormemente como a emissão de gases de efeito estufa (GEE). A pecuária leiteira, considerada uma das principais fontes de alimento, vem ampliando suas fronteiras de exploração para o suprimento da crescente demanda por leite. Essa situação pode contribur com o aumento das emissões de GEE se não forem adotadas medidas para o gerenciamento adequado dos detritos gerados.

Dentre os GEE, destaca-se o gás carbônico $\left(\mathrm{CO}_{2}\right)$, óxidos nitrosos $\left(\mathrm{NO}_{\mathrm{X}}\right)$, metano $\left(\mathrm{CH}_{4}\right)$ e os halocarbonos, emitidos pela queima de combustíveis fósseis, queima de biomassa e produção agropecuária, refrigeração e aerossóis, respectivamente (LIBORIO, 2005).

Para estudar o problema das emissões de GEE, foi criado pela Organização das Nações Unidas (ONU), em 1988, o Painel Intergovernamental sobre Mudanças 
Climáticas (IPCC). Em seu primeiro relatório, de 1990, o Painel afirmava que em cem anos o nível de $\mathrm{CO}_{2}$ dobraria, elevando a temperatura média global entre 1,0 e $3,5^{\circ} \mathrm{C}$. Como comparação, no século XIX esse aumento ficou entre 0,3 e $0,6^{\circ} \mathrm{C}$ (BNDES, 1999).

Nos últimos 70 anos, registrou-se um aumento médio de $0,6^{\circ} \mathrm{C}$ na temperatura da superfície do globo. Vale citar que os níveis de $\mathrm{CO}_{2}$ aumentaram de 280 ppm, no período que antecede à Revolução Industrial, para quase 360 ppm em volume nos dias de hoje (BNDES, 1999).

Na ECO-92 (Conferência das Nações Unidas sobre o Meio Ambiente e Desenvolvimento - UNCED), realizada no Rio de Janeiro em 1992, nasceu a Convenção-Quadro das Nações Unidas sobre Mudança do Clima (UNFCC) com objetivo de combater o efeito estufa provocado por intervenção antrópica. Essa é hoje a principal fonte normativa internacional a regular a questão.

Posteriormente, foi assinado o Protocolo de Kyoto, estabelecendo metas de redução na emissão de GEE. O protocolo exige que os países desenvolvidos (Partes constantes do Anexo I), reduzam em média 5,2\% de suas emissões de gases de efeito estufa até o ano 2012, tendo como base os índices de 1990, enquanto os países em desenvolvimento (Partes não Anexo I) assumem o compromisso de se desenvolverem de maneira mais limpa e sustentável. Os países do Anexo I assumem maiores e mais restritivas obrigações por conta da forma predatória com que alcançaram seu atual grau de riqueza.

A contribuição do Brasil no delineamento do Protocolo de Kyoto foi marcante, com a apresentação de diversas propostas relevantes, dentre as quais a da criação de um Fundo de Desenvolvimento Limpo, que posteriormente se transformou no atual Mecanismo de Desenvolvimento Limpo, que junto com o comércio de emissões e a Implementação Conjunta, foram estabelecidos pelo protocolo para ajudar às partes constantes do Anexo I da UNFCC a reduzir os custos para o cumprimento das metas de emissões (LIBORIO, 2005). 


\subsection{O Mecanismo de Desenvolvimento Limpo (MDL)}

O Mecanismo de Desenvolvimento Limpo (MDL) é um instrumento previsto no artigo 12 do Protocolo de Kyoto, com o intuito de ajudar os países emergentes, incentivando-os a alcançar o desenvolvimento sustentável. Ao mesmo tempo, ele flexibiliza as exigências aos países desenvolvidos que não consigam ou não queiram cumprir suas metas de redução de emissões, por meio da comercialização de Certificados de Emissões Reduzidas (CERs). Esses certificados, também chamados de "Créditos de Carbono", são uma espécie de moeda ambiental, apresentada por partes não Anexo I ao secretariado do MDL para colocação no mercado.

Os CERs podem ser obtidos por diversos meios, tais como:

- projetos que absorvam gases de efeito estufa da atmosfera, como o reflorestamento, por exemplo;

- redução das emissões provenientes da queima de combustíveis fósseis;

- substituição de combustíveis fósseis por fontes renováveis;

- aproveitamento das emissões, que de outra maneira seriam descarregados na atmosfera, para geração de energia, como por exemplo o aproveitamento do biogás produzido em aterros sanitários ou em biodigestores para o gerenciamento adequado dos resíduos agropecuários, tais como os detritos animais e restos de cultura, entre outros.

\subsubsection{Etapas de um Projeto MDL}

Com a vigência do Protocolo de Kyoto, para que os projetos de Mecanismo de Desenvolvimento Limpo possam gerar créditos de carbono, estes projetos devem utilizar metodologias de avaliação, monitoramento e verificação aprovados e reconhecidos pela Junta Executiva do MDL. Assim, cada projeto submetido passa por uma criteriosa avaliação antes que que ele possa gerar e vender créditos de carbono. 
Quando os projetos são concebidos, estes devem se adequar às metodologias já aprovadas ou desenvolver novas metodologias que sujeitam, portanto, o projeto a uma fase de pré-análise. É importante entender esse processo, pois à medida que novas metodologias são aprovadas dissemina-se o conhecimento técnico obtido e permite-se a sua replicabilidade, esperando-se assim uma redução de esforços e custos operacionais na elaboração de projetos e agilização dos procedimentos transacionais do MDL.

As fases para o registro de um Projeto MDL (ADD Consultoria, 2006) são:

- Prospecção de oportunidade de desenvolver um projeto MDL;

- estudo de viabilidade técnica (EVT);

- desenvolvimento do Documento de Concepção do Projeto MDL (DCP);

- apresentação do DCP a uma Entidade Operacional Designada pela ONU (EOD);

- obtenção da carta de encaminhamento do DCP à ONU, junto à Comissão Interministerial sobre Mudança Global do Clima (CIMGC);

- registro do projeto junto ao Conselho Executivo da ONU;

- implantação e monitoramento do projeto;

- verificação do monitoramento junto a uma EOD;

- obtenção (certificação) e comercialização dos créditos de carbono.

\subsubsection{O Brasil e a Redução de Emissões}

O Brasil, como país em desenvolvimento, não é obrigado a reduzir suas emissões, porém mesmo antes da ratificação do Protocolo de Kyoto o empresariado brasileiro se preparou para tirar proveito do mercado de créditos de carbono. Assim, o primeiro acordo desse tipo foi fechado em 2002, entre o Fundo Protótipo de Carbono do Banco Mundial e a siderúrgica mineira Plantar, visando a substituição de 
carvão mineral por vegetal, advindo do estabelecimento de plantios sustentáveis de florestas de eucalipto, para a redução de $\mathrm{CO}_{2}$ e $\mathrm{CH}_{4}$ em 13 milhões de toneladas equivalentes de $\mathrm{CO}_{2}$ em um período de 28 anos (GRUPO PLANTAR, 2006).

Especialistas estimam que no mundo os créditos de carbono movimentarão US\$ 13 bilhões em 2007. Assim, os países em desenvolvimento terão à disposição capital estrangeiro de baixo custo para promover o desenvolvimento sustentável e a geração de empregos.

Segundo o Banco Mundial, o Brasil respondeu por $12 \%$ do volume total de projetos MDL negociados no período de janeiro de 2003 a dezembro de 2004. E $13 \%$ do volume total negociado entre janeiro de 2004 e abril de 2005 (BRUNACCI, 2005).

Embora não existam metas oficiais de aumento da participação brasileira em projetos MDL, estudo do Núcleo de Assuntos Estratégicos (NAE) da Presidência da República estima que a demanda por créditos de emissões, em 2012, seja de US\$ 30 bilhões por ano e a futura participação brasileira fique em, no mínimo, 10\% deste mercado (BRUNACCI, 2005).

Os projetos MDL apresentam em geral altos custos de implementação, principalmente na fase inicial, em que o processo de aprendizagem está em curso e as metodologias estão ainda em fase de consolidação, onerando particularmente os projetos de pequeno porte. Para superar obstáculos dessa natureza, seria conveniente o exame de mecanismos de incentivo adequados.

Existem atualmente 244 projetos de MDL em andamento em todo o mundo Os principais países beneficiados são, pela ordem, o Brasil, a Índia e a China, com 74 (30\% do total), 54 (22\%) e 14 (8\%) projetos em andamento (GUIMARÃES, 2005).

A maioria desses projetos se relaciona com geração de energia ou de manejo e tratamento de resíduos. A negociação de créditos de carbono já beneficia uma série de empresas siderúrgicas, de papel e celulose, agroindustriais, de reflorestamento, dentre outros. Consequientemente, no primeiro período de crédito dos projetos, conseguiu-se reduzir as emissões em cerca de 130 milhões de toneladas-equivalentes 
de $\mathrm{CO}_{2}$, o que corresponde a cerca de $10 \%$ do inventário brasileiro de 1990 (GUIMARÃES, 2005).

Portanto, iniciativas para o aproveitamento de fontes alternativas renováveis de energia como o biogás (aterro sanitário, dejetos animais, esgoto), carvão vegetal, biodiesel, casca de arroz e bagaço de cana e o reflorestamento, contribuirão no acréscimo de projetos de MDL.

\subsection{Emissões do Setor Pecuário}

O adequado gerenciamento do esterco na pecuária contribui significativamente com a redução das emissões de metano. Por exemplo, na Nova Zelândia essas emissões correspondem a 49,2 \% do total de emissões da agricultura (REUTERS, 2005).

De acordo com Souza (2005) há a intenção de muitos investidores de colocarem dinheiro em projetos que envolvam biodigestores. Segundo essa fonte, uma empresa irlandesa, especializada na venda de créditos de carbono, com unidades no Brasil, Canadá, EUA, Irlanda e México já construiu cerca de 500 biodigestores no Brasil, pretendendo chegar em breve aos 1,5 mil. Essa empresa entra com o dinheiro para bancar o equipamento na propriedade do produtor, que fica encarregado pela operação do biodigestor, podendo utilizar o biogás e o efluente, e, além disso, recebe $10 \%$ da renda obtida com a comercialização dos créditos de carbono pela empresa.

Até o 2015 (um período de 10 anos aproximadamente), essa empresa quer investir no Brasil entre US\$ 100 milhões e US\$ 150 milhões em projetos em fazendas de suínos e bovinos. Os aportes serão utilizados desde a infra-estrutura até as operações de venda dos créditos de carbono.

Segundo a comunidade virtual Suíno.com (2005), outras iniciativas para a redução das emissões próprias dos dejetos animais vêm sendo desenvolvidas por empresas brasileiras em projetos de construção de biodigestores nas propriedades suinícolas, financiados pelo Banco Mundial a fundo perdido. 
Da mesma forma, o Governo do Estado de Minas Gerais, pretende construir unidades demonstrativas de biodigestores em Bambuí, Rio Pomba e Viçosa, em parceria com universidades federais (REVISTA NEGÓCIOS, 2006).

Atualmente existem duas metodologias de de referência aprovadas pelo Conselho Executivo do MDL: a AM0016 e a AM0006. Ambas são destinadas ao manejo adequado de resíduos animais, porém foram colocadas novamente em análise pelo Painel de Metodologias devido à falta de regras claras para o monitoramento da queima do metano em "flares" 5 ". O Conselho Executivo do MDL está atualmente recebendo comentários públicos sobre essa questão, bem como a colaboração de consultores especializados (ECONERGY, 2006).

Segundo o último informativo da consultoria Econergy, desde março de 2006 o preço do credito de carbono tem-se mantido acima dos €9,00, com um ligeiro crescimento a cada mês, até ter atingido um valor aproximado de $€ 13,00$ em agosto passado (ECONERGY, 2006).

\subsection{Projeto MDL para Fazendas Leiteiras}

Os herbívoros ruminantes, como bovinos, ovinos, bubalinos e caprinos, geram metano por meio da fermentação entérica, um processo digestivo que ocorre no rúmen do animal. As emissões globais desse gás geradas a partir dos processos entéricos são estimadas em 80 milhões de toneladas anuais, correspondendo a cerca de $22 \%$ das emissões totais de metano geradas por fontes antrópicas (U.S. EPA, 2000 apud LIMA, 2002). As emissões de metano próprias dos dejetos animais representam uma menor parcela, porém potencialmente poluidora, de aproximadamente 5\% das emissões por fermentação entérica.

No ano 2000 foi apresentado o primeiro inventário brasileiro de emissões de metano da pecuária, elaborado conforme contrato firmado entre o Programa das

\footnotetext{
${ }^{5}$ Flare: queimador do tipo tocha, usado para queimar o biogás diretamente no ambiente
} 
Nações Unidas para o Desenvolvimento (PNUD), a agência implementadora do Fundo Global para o Meio Ambiente e a Empresa Brasileira de Pesquisa Agropecuária (EMBRAPA), no âmbito do Projeto BRA/95/G31, com apoio financeiro (acordo bilateral) do United States Country Studies Program (LIMA et al., 2006).

Segundo esse inventário, do total das emissões de metano provenientes de atividades agrícolas em 1994, a pecuária contribui com cerca de 96\%, correspondendo a cerca de 9,8 milhões de toneladas de $\mathrm{CH}_{4}$, das quais 9,4 milhões são atribuídas à fermentação entérica e o restante aos sistemas de gerenciamento do esterco animal. Naquele ano o Brasil possuía cerca de 158 milhões de cabeças de gado, sendo $87 \%$ de gado de corte e $13 \%$ de gado leiteiro (LIMA et al., 2006).

A maior parte desses animais pertencem a pequenos proprietários, que operam sistemas de produção extensivo e de baixo investimento de capital. O gado é geralmente alimentado com forragens com baixa qualidade nutricional, promovendo baixo crescimento, um lento desempenho reprodutivo e baixa produção de leite. Os aumentos de produção são devidos mais ao aumento do número de animais que a uma melhora na produtividade (LIMA, 2002).

Para evitar a acumulação dos dejetos animais e a conseqüente proliferação de doenças e infecções na fazenda leiteira, a limpeza diária dos estábulos e o manejo dos dejetos como líquido é apontada como uma forma adequada para o seu gerenciamento, sendo as lagoas anaeróbicas os sistemas de tratamento mais simples. Porém, esse tipo de sistema intensifica as emissões de metano.

No Brasil, devido às características de pecuária extensiva, as lagoas de tratamento anaeróbico constituem apenas uma pequena fração dos sistemas de manejo. Mesmo para o gado confinado, observa-se o uso restrito de instalações de tratamento de dejetos animais (LIMA et al, 2006). Os dejetos produzidos acabam sendo depositados no campo como material sólido, onde secam e se decompõem.

Como já destacado anteriormente, sendo a especialização da atividade leiteira um requisito para acompanhar as crescentes mudanças do mercado, e como parte do 
desenvolvimento sustentável do agronegócio, a aplicação da digestão anaeróbica no gerenciamento do esterco do gado leiteiro para eventual aproveitamento energético do biogás, apresenta as características básicas de um projeto MDL. As consequiências serão positivas, desde que tragam benefícios às partes envolvidas, principalmente relacionadas com um aumento da eficiência energética global da fazenda leiteira e com um aumento na lucratividade da atividade ao longo da vida útil do projeto por meio das rendas associadas aos créditos de carbono (CERs).

Sendo o foco do presente estudo a eventual utilização do biogás produzido como insumo energético para o resfriamento do leite in loco e não o desenvolvimento de um projeto MDL de digestão anaeróbica em fazendas leiteiras, será abordada unicamente a preparação do DCP no que se refere à quantificação e comparação das emissões de GEE do projeto proposto em relação a uma configuração de referência, destacando o potencial de redução de emissões e a quantidade de biogás disponível para posterior utilização. Essa quantificação será feita utilizando o Manual de Referência do Intergovernmental Panel on Climate Change (IPCC, 1996).

\subsection{Quantificação das Emissões}

No presente estudo, para a quantificação das emissões de gases de efeito estufa (GEE) foram considerados principalmente dois gases: o metano $\left(\mathrm{CH}_{4}\right)$ e o óxido nitroso $\left(\mathrm{NO}_{2}\right)$. Quantificou-se a emissão de cada um deles, calculou-se os possíveis vazamentos e, finalmente, a redução líquida aparente de emissões de GEE.

\subsubsection{Emissões de Metano $\left(\mathrm{CH}_{4}\right)$}

As emissões de metano podem ocorrer de duas formas:

- fermentação entérica;

- gerenciamento do esterco. 


\subsubsection{Fermentação Entérica}

Os bovinos, como outros herbívoros ruminantes, produzem metano através da fermentação entérica (processo próprio do processo digestivo que ocorre no rúmen do animal). O primeiro passo na quantificação dessas emissões é caracterizar uma série de parâmetros como a composição da população animal por tipo e quantidade de cabeças, a dieta alimentar diária média, que varia com o peso do animal, tipo de criação (confinamento, pastoreio, etc.), e a porcentagem de vacas grávidas por ano, entre outros.

Definidos esses parâmetros, o fator de emissão de metano por fermentação entérica $\left(\mathrm{FE}_{\mathrm{CH} 4, \mathrm{fe}}\right)$ é calculado conforme descrito a seguir:

\section{a) Requerimento Energético Líquido do Animal (EN)}

Refere-se à somatória da energia (MJ/dia) requerida pelas funções fisiológicas do animal (metabolismo, crescimento, lactação, alimentação e gravidez).

a.1) metabolismo:

$$
\mathrm{EN}_{\mathrm{m}}=0,335 \times\left(\mathrm{m}_{\text {vaca }}\right)^{0,75}
$$

onde $\mathrm{m}_{\text {vaca }}$ é o peso da vaca $(\mathrm{kg})$.

a.2) Crescimento:

$$
\mathrm{EN}_{\mathrm{cr}}=4,18 \times\left\lfloor\left(0,035 \times\left(\mathrm{m}_{\text {vaca }}\right)^{0,75} \times\left(\mathrm{m}_{\mathrm{g}}\right)^{1,119}\right)+\mathrm{m}_{\mathrm{g}}\right\rfloor
$$


ou

$$
\mathrm{EN}_{\mathrm{cr}}=(1,42 \times \mathrm{EM})-\left(0,174 \times \mathrm{EM}^{2}\right)+\left(0,0122 \times \mathrm{EM}^{3}\right)-1,65
$$

onde $\mathrm{m}_{\mathrm{g}}$ é peso ganho por vaca em $\mathrm{kg}$ (sendo igual a zero para vaca madura), e EM é a energia metabolisável, dada por:

$$
\mathrm{EM}=0,82 \times \mathrm{ED}
$$

onde ED é a energia digestível, porção aproveitada pelo animal e não excretada, que por sua vez é função do tipo de alimentação do animal. Como referência, a energia digestível para alguns tipos de alimentação é:

- subprodutos do milho - 50 a $60 \%$ da energia bruta do alimento;

- dietas baseadas em forragem e grãos como suplemento - 60 a 70\%;

- dieta baseada em grãos em regime de confinamento - 75 a $85 \%$.

a.3) Lactação

$$
\mathrm{EN}_{1}=\mathrm{m}_{\text {leite }} \times\left(1,47+0,4 \times \mathrm{TG}_{\text {leite }}\right)
$$

onde $\mathrm{m}_{\text {leite }}$ é a produção diária de leite $(\mathrm{kg} / \mathrm{dia})$ e $\mathrm{TG}_{\text {leite }} \mathrm{o}$ teor de gordura.

$$
\text { a.4) Alimentação }
$$




$$
\mathrm{EN}_{\mathrm{al}}=\left(\mathrm{F}_{\mathrm{A}}\right) \times \mathrm{EN}_{\mathrm{m}}
$$

onde $\mathrm{F}_{\mathrm{A}}$ é um fator determinado pelo tipo de criação do animal, sendo igual a 0 para confinamento, 0,17 para pastoreio intensivo, e 0,37 para pastoreio extensivo.

a.5) Prenhez

$$
\mathrm{EN}_{\mathrm{pr}}=0,075 \times \mathrm{EN}_{\mathrm{m}}
$$

\section{b) Energia Bruta Ingerida (EB)}

Refere-se ao total de energia que é ingerida pelo animal durante o processo de alimentação (Eq. 5.8).

$$
\mathrm{EB}=\frac{\left(\mathrm{EN}_{\mathrm{m}}+\mathrm{EN}_{1}+\mathrm{EN}_{\mathrm{al}}+\mathrm{EN}_{\mathrm{pr}}\right) \times\left(\frac{100}{\mathrm{ED}}\right)}{\left(\frac{\mathrm{EN}}{\mathrm{ED}}\right)+\left[\frac{\mathrm{EN}_{\mathrm{cr}}}{\left.\mathrm{EN}_{\mathrm{cr} / \mathrm{ED}}\right]}\right.}
$$

Considerando uma digestibilidade menor ou igual a $65 \%$, os termos no denominador podem ser determinados por:

$$
\begin{aligned}
& \frac{\mathrm{EN}}{\mathrm{ED}}=0,298+(0,00335 \times \mathrm{ED}) \\
& \frac{\mathrm{EN}_{\mathrm{cr}}}{\mathrm{ED}}=-0,036+(0,00535 \times \mathrm{ED})
\end{aligned}
$$


c.) Fator de Emissão de Metano e Emissão por Fermentação Entérica

O fator de emissão por fermentação entérica (kg/vaca.ano) é dado por:

$$
\mathrm{FE}_{\mathrm{CH}_{4}, \mathrm{fe}}=\frac{365 \times \mathrm{EB} \times \mathrm{TCM}}{55,65\left(\mathrm{MJ} / \mathrm{kg}_{\mathrm{CH}_{4}}\right)}
$$

onde TCM é a taxa de conversão de metano, que para vacas leiteiras maduras com razoável nível de alimentação em regime confinado, varia de $4 \%$ e $6 \%$, sendo menor quanto maior for a qualidade do alimento (alta digestibilidade) (IPCC, 1996).

Uma vez determinado o fator de emissão, tem-se que a emissão total de metano

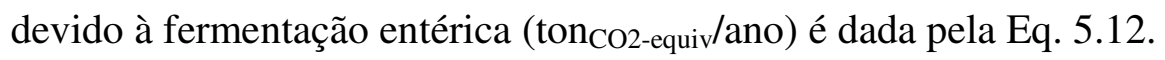

$$
\mathrm{ET}_{\mathrm{CH}_{4}, \mathrm{fe}}=\left(\mathrm{FE}_{\mathrm{CH}_{4}, \mathrm{fe}} \times \mathrm{n}\right) \times \frac{\mathrm{GWP}_{\mathrm{CH}_{4}}}{1000}
$$

onde $\mathrm{n}$ é o número de cabeças considerado, e GWP é o potencial de aquecimento global do metano em relação ao $\mathrm{CO}_{2}$.

\subsubsection{Gerenciamento do Esterco}

O cálculo das emissões de metano pelo sistema de gerenciamento de esterco animal (SGEA) é feito a partir da quantidade de sólidos voláteis presente no esterco e do potencial de produção de metano (Bo), tabelado pelo IPCC (Tab. 5.1), levando em conta a região do planeta em que a fazenda estiver situada. 
Tabela 5.1. Potencial de produção de metano e sólidos voláteis de gado leiteiro

\begin{tabular}{cccc}
\hline Região & \multicolumn{3}{c}{ Características do gado leiteiro } \\
& $\begin{array}{c}\text { Massa } \\
(\mathrm{kg})\end{array}$ & $\begin{array}{c}\text { Bo } \\
\left(\mathrm{m}^{3} \mathrm{CH}_{4} / \mathrm{kg}_{\mathrm{SV}}\right)\end{array}$ & $\begin{array}{c}\mathrm{SV} \\
\mathrm{kg} / \mathrm{animal} / \mathrm{dia}\end{array}$ \\
\hline América do Norte & 600 & 0,24 & 5,2 \\
Oeste Europeu & 550 & 0,24 & 5,1 \\
Leste Europeu & 550 & 0,24 & 4,1 \\
Oceania & 500 & 0,24 & 3,5 \\
América Latina & 400 & 0,13 & 2,9 \\
África & 275 & 0,13 & 1,9 \\
Oriente Médio & 275 & 0,13 & 1,9 \\
Ásia & 350 & 0,13 & 2,8 \\
\hline
\end{tabular}

Fonte: Manual de Referência do IPCC (1996)

Os sólidos voláteis (SV) representam a matéria orgânica degradável do esterco, e sua quantidade é estimada a partir da energia bruta ingerida pelo animal (EB), segundo a Eq. 5.13.

$$
\mathrm{SV}=\mathrm{EB} \times \frac{1 \mathrm{~kg}_{\mathrm{ms}}}{18,45 \mathrm{MJ}} \times\left(1-\frac{\mathrm{ED}}{100}\right) \times\left(1-\frac{\mathrm{C}_{\mathrm{CI}}}{100}\right)
$$

onde $\mathrm{C}_{\mathrm{CI}}$ é o conteúdo de cinza no esterco (aproximadamente de $8 \%$ para gado) e ED a energia digestível do alimento.

O fator de emissão de metano para o SGEA ( $\left.\mathrm{FE}_{\mathrm{CH} 4, \mathrm{SGEA}}\right)$ será dado por:

$$
\mathrm{FE}_{\mathrm{CH}_{4}, \mathrm{SGEA}}=365 \times\left[\mathrm{Bo} \times \mathrm{SV} \times\left(\frac{\mathrm{FCM}}{100}\right)\right] \times \rho_{\mathrm{CH}_{4}}
$$


onde Bo é o potencial de produção de metano, FCM é o fator de conversão de metano, encontrado na Tab. 5.2 em função do tipo de SGEA utilizado e do clima da região, e $\rho_{\mathrm{CH} 4}$ é a massa específica do metano $\left(\mathrm{kg} / \mathrm{m}^{3}\right)$. Uma vez determinado $\mathrm{FE}_{\mathrm{CH} 4, \mathrm{SGEA}}$, a emissão total de metano do SGEA é dada por:

$$
\mathrm{ET}_{\mathrm{CH}_{4}, \mathrm{SGEA}}=\left(\mathrm{FE}_{\mathrm{CH}_{4}, \mathrm{SGEA}} \times \mathrm{n}\right) \times \frac{\mathrm{GWP}_{\mathrm{CH}_{4}}}{1000}
$$

Onde $\mathrm{GWP}_{\mathrm{CH} 4}$ representa o potencial de aquecimento global do metano e tem um valor de 21 (o metano é 21 vezes mais nocivo que o dióxido de carbono).

Tabela 5.2. Fator de conversão de metano (FCM)

\begin{tabular}{cccc}
\hline SGEA & Clima \\
& Frio & temperado & quente \\
\hline Lagoa anaeróbica (lagoon) & $90,0 \%$ & $90,0 \%$ & $90,0 \%$ \\
Lodo (liquid) & $10,0 \%$ & $35,0 \%$ & $65,0 \%$ \\
Estocagem sólida (solid storage) & $1,0 \%$ & $1,5 \%$ & $2,0 \%$ \\
Lote seco (drylot) & $1,0 \%$ & $1,5 \%$ & $5,0 \%$ \\
Pastagem (pasture/range) & $1,0 \%$ & $1,5 \%$ & $2,0 \%$ \\
Esterco armazenado no local de origem e usado & $0,1 \%$ & $0,5 \%$ & $1,0 \%$ \\
posteriormente como adubo (daily spread) & \multicolumn{3}{c}{$5-10,0 \%$} \\
Digestor (digester) \\
Queima como combustível (burned for fuel) & $10,0 \%$ & $10,0 \%$ & $0,0 \%$ \\
Outros & $1,0 \%$ & $1,0 \%$ & $1,0 \%$ \\
\hline
\end{tabular}

Fonte: Manual de Referência do IPCC (1996)

\subsubsection{Emissões de Óxido Nitroso $\left(\mathrm{N}_{2} \mathrm{O}\right)$ dos SGEA}

Essas emissões dependem da quantidade de nitrogênio ingerida nos alimentos. A retenção de nitrogênio em produtos animais como o leite, carne, é de 5 a $20 \%$ do 
total de nitrogênio ingerido, e que o resto é excretado na urina e nos dejetos fecais, que irão para o SGEA.

As emissões de $\mathrm{N}_{2} \mathrm{O}$ correspondem às emissões diretas, próprias do SGEA usado e da volatilização do nitrogênio e outros, bem como às emissões indiretas devidas à disposição da matéria orgânica no campo. Sendo as primeiras as mais significativas e de interesse à etapa do gerenciamento do esterco, para o seu cálculo, utiliza-se:

$$
\mathrm{ET}_{\mathrm{N}_{2} \mathrm{O}}=\left(\mathrm{FE}_{\mathrm{N}_{2} \mathrm{O}} \times \mathrm{n}\right) \times \frac{\mathrm{GWP}_{\mathrm{N}_{2} \mathrm{O}}}{1000}
$$

onde $\mathrm{GWP}_{\mathrm{N} 2 \mathrm{O}}$ representa o potencial de aquecimento global do óxido nitroso e tem um valor de 310 (ou seja, o $\mathrm{N}_{2} \mathrm{O}$ é 310 vezes mais nocivo que o dióxido de carbono), $\mathrm{FE}_{\mathrm{N} 2 \mathrm{O}}$ é o fator de emissão oxido nitroso e $\mathrm{n}$ o número de animais. $\mathrm{O}$ fator $\mathrm{FE}_{\mathrm{N} 2 \mathrm{O}}$, por sua vez, é dado por:

$$
\mathrm{FE}_{\mathrm{N}_{2} \mathrm{O}}=\mathrm{Nex} \times \mathrm{FE}_{\mathrm{SGEA}} \times \mathrm{C}_{\mathrm{m}}
$$

onde $\mathrm{N}_{\mathrm{ex}}$ é a excreção de nitrogênio ( $\mathrm{kg}_{\mathrm{N}} /$ animal.ano), dada pela Tab. 5.3, $\mathrm{C}_{\mathrm{m}}$ é o fator de conversão de $\mathrm{N}_{2} \mathrm{O}-\mathrm{N}$ para $\mathrm{N}_{2} \mathrm{O}(44 / 28)$ e $\mathrm{FE}_{\text {SGEA }}$ é o fator de emissão de $\mathrm{N}_{2} \mathrm{O}$ em função do tipo de SGEA, dado pela Tabela 5.4. 
Tabela 5.3. Taxa de excreção de nitrogênio segundo a região (kg/animal/ano)

\begin{tabular}{ccccccc}
\hline \multirow{2}{*}{ Região } & \multicolumn{5}{c}{ Tipo de animal } \\
& Gado $\begin{array}{c}\text { Gado } \\
\text { leiteiro }\end{array}$ & Aves & Ovelha & Suínos & $\begin{array}{c}\text { Outros } \\
\text { Animais }\end{array}$ \\
\hline América do Norte & 70 & 100 & 0,6 & 16 & 16 & 25 \\
Oeste Europeu & 70 & 100 & 0,6 & 20 & 20 & 25 \\
Leste Europeu & 50 & 70 & 0,6 & 16 & 16 & 25 \\
Oceania & 60 & 80 & 0,6 & 20 & 20 & 25 \\
América Latina & 40 & 70 & 0,6 & 12 & 12 & 40 \\
África & 40 & 60 & 0,6 & 12 & 12 & 40 \\
Oriente Médio e Mediterrâneo & 50 & 70 & 0,6 & 12 & 12 & 40 \\
Ásia e Extremo Oriente & 40 & 60 & 0,6 & 12 & 12 & 40 \\
\hline
\end{tabular}

Fonte: Manual de Referencia do IPCC (1996)

Tabela 5.4. Valores estimados para os fatores de emissão de $\mathrm{N}_{2} \mathrm{O}$ de diversos sistemas de gerenciamento de detritos animais $\left(\mathrm{kg}_{\mathrm{N} 2 \mathrm{O}-\mathrm{N}} / \mathrm{kg}_{\mathrm{Nex}}\right)$.

\begin{tabular}{cc}
\hline SGEA & FE $_{\text {SGEA }}$ \\
\hline Lagoa anaeróbica & $0,001(<0,002)$ \\
Sistemas líquidos & $0,001(<0,001)$ \\
Espalhamento diário & 0 \\
Armazenamento sólido e drylot & $0,02(0,005-0,03)$ \\
Pastagem & $0,02(0,005-0,03)$ \\
Outros sistemas & 0,005 \\
\hline
\end{tabular}

Fonte: Manual de Referencia do IPCC (1996)

\subsection{Redução de Emissões de GEE}

A redução de emissões de GEE da atividade de um projeto de MDL será dada pela diferença entre as emissões da configuração de referência (CR) e as emissões do projeto (PR), ou seja:

$$
\mathrm{RE}=\mathrm{ET}_{\mathrm{CR}}-\mathrm{ET}_{\mathrm{PR}}
$$




\section{ENGENHARIA DE CUSTOS}

\subsection{Introdução}

Para a avaliação se um determinado projeto é tecnicamente viável e se sua implementação é capaz de alcançar as metas traçadas pelo empreendedor, a análise econômica tem um papel importante no processo de tomada de decisão e escolha da alternativa mais adequada dentre as várias alternativas disponíveis.

Os itens a seguir apresentam alguns conceitos e definições de engenharia econômica que serão utilizados neste trabalho para a análise do impacto da inserção e aprimoramento de sistemas térmicos para o resfriamento do leite produzido na fazenda.

\subsection{Valores Presentes}

\subsubsection{Valor Presente de Um Valor Futuro}

$\mathrm{O}$ valor presente de um valor futuro representa o montante que se investido hoje sob uma determinada taxa de juros, produziria um determinado valor em uma data particular do futuro. Trazer esse valor para o presente, permite comparar seu valor "hoje".

O valor presente (VP) é dado por:

$$
\mathrm{VP}_{\mathrm{F}}=\mathrm{P}=\frac{\mathrm{F}}{(1+\mathrm{i})^{\mathrm{n}}}=\mathrm{F} \times(1+\mathrm{i})^{-\mathrm{n}}
$$


Onde F é o valor adicionado no futuro, $\mathrm{P}$ o valor presente, i a taxa de juros e $\mathrm{n}$ o número de anos considerado na análise.

Alguns autores preferem expressar o valor presente, da seguinte forma:

$$
\mathrm{VP}=(\mathrm{F}) \times(\mathrm{P} / \mathrm{F}, \mathrm{i}, \mathrm{n})
$$

sendo $(\mathrm{P} / \mathrm{F})$ o fator de valor presente, dado por:

$$
\mathrm{P} / \mathrm{F}=(1+\mathrm{i})^{-\mathrm{n}}
$$

\subsubsection{Valor Presente de uma Série Uniforme de Montantes $\left(V P_{S}\right)$}

Representa o valor presente de uma série de montantes iguais, pagos cada final de ano por um determinado período. É determinado segundo o fator de valor presente $(\mathrm{P} / \mathrm{F})$.

$$
\mathrm{VP}_{\mathrm{S}}=(\mathrm{F}) \times(\mathrm{P} / \mathrm{F}, \mathrm{i}, \mathrm{n})
$$

onde para os montantes iguais, tem-se que:

$$
\mathrm{F}=\mathrm{S} \times\left[\frac{(1+\mathrm{i})^{\mathrm{n}}-1}{\mathrm{i}}\right] \times(\mathrm{P} / \mathrm{F}, \mathrm{i}, \mathrm{n})
$$

Portanto, para o valor presente de uma série $\left(\mathrm{VP}_{\mathrm{S}}\right)$ temos: 


$$
\begin{gathered}
\mathrm{VP}_{\mathrm{S}}=\mathrm{S} \times\left[\frac{(1+\mathrm{i})^{\mathrm{n}}-1}{\mathrm{i}}\right] \times\left(\frac{1}{(1+\mathrm{i})^{\mathrm{n}}}\right) \\
\mathrm{VP}_{\mathrm{S}}=\mathrm{S} \times\left[\frac{(1+\mathrm{i})^{\mathrm{n}}-1}{\mathrm{i} \times(1+\mathrm{i})^{\mathrm{n}}}\right]
\end{gathered}
$$

Da mesma forma que no caso anterior, a Eq. 6.7 acima pode ser expressa como:

$$
\mathrm{VP}_{\mathrm{S}}=(\mathrm{S}) \times(\mathrm{P} / \mathrm{S}, \mathrm{i}, \mathrm{n})
$$

sendo $\mathrm{P} / \mathrm{S}$ o fator de valor presente de séries

$$
\mathrm{P} / \mathrm{S}=\left[\frac{(1+\mathrm{i})^{\mathrm{n}}-1}{\mathrm{i} \times(1+\mathrm{i})^{\mathrm{n}}}\right]
$$

\subsection{Custo de Capital ou Investimento Total (IT)}

Representa os recursos econômicos que são inseridos em um determinado empreendimento, para sua operação. Esse custo de investimento engloba custos diretos (CDT) e indiretos totais (CIT):

$$
\mathrm{IT}=\mathrm{CDT}+\mathrm{CIT}
$$

onde 


$$
\begin{gathered}
\mathrm{CDT}=\mathrm{C}_{\text {equipamento }}+\mathrm{C}_{\text {instalação }}+\mathrm{C}_{\text {preparação-área }} \\
\mathrm{CIT}=\mathrm{C}_{\text {ad min istrativos }}+\mathrm{C}_{\text {impostos }}+\mathrm{C}_{\text {seguros }}+\ldots \ldots . .
\end{gathered}
$$

\subsection{Custo Anual Total (CAT)}

Também denominado custo de operação e manutenção, é dado por:

$$
\mathrm{CAT}=\mathrm{CAD}+\mathrm{CAI}
$$

onde CAD e CAI são os custos anuais diretos e indiretos, dados pelas Eqs. (6.14) e (6.15):

$$
\begin{gathered}
\mathrm{CAD}=\mathrm{C}_{\text {matéria prima }}+\mathrm{C}_{\text {operacional }}+\mathrm{C}_{\text {manutenção }}+\mathrm{C}_{\text {serviços }}+\ldots \\
\mathrm{CAI}=\mathrm{C}_{\text {ad min istrativos }}+\mathrm{C}_{\text {impostos }}+\mathrm{C}_{\text {seguro }}+\ldots
\end{gathered}
$$

\subsection{Técnicas de Análise de Investimento}

Na tomada de decisão por parte das firmas ou empreendedores em que projetos investirem, são utilizados indicadores econômicos. Entre os mais usados destacam o valor atual líquido (VAL), a taxa interna de retorno (TIR); definidos a seguir.

\subsubsection{Método do Valor Presente Líquido (VPL)}

O VPL é o critério mais recomendado por especialistas em finanças para decisão de investimento, uma vez que o método considera o valor temporal do 
dinheiro (uma unidade monetária disponível hoje vale mais do que amanhã, porque ela pode ser investida e render juros), não é influenciado por decisões menos qualificadas (preferências do gestor, métodos de contabilização, rentabilidade da atividade atual), e utiliza todos os fluxos de caixa futuros gerados pelo projeto, refletindo assim toda a movimentação de caixa.

Além disso, esse método permite uma decisão mais acertada quando há dois tipos de investimentos, pois, ao considerar os fluxos futuros a valores presentes, os fluxos podem ser adicionados e analisados conjuntamente.

O VPL é dado por:

$$
\mathrm{VPL}=-\mathrm{IT}+\sum \mathrm{VP}(\mathrm{P} / \mathrm{F}, \mathrm{i}, \mathrm{n})
$$

\subsubsection{Método da Taxa Interna de Retorno (TIR)}

Constitui um caso especial do método VPL, em que o valor presente líquido é considerado zero, deixando a taxa de juros como uma variável independente.

Assim:

$$
0=-\mathrm{IT}+\mathrm{VPL}
$$

A TIR encontrada deverá ser comparada com a taxa de juros no momento da decisão do investimento ou financiamento. Como regra geral para tomadas de decisão de investimento, tem-se que:

- $\quad$ Se TIR $>\mathrm{i} \rightarrow$ VPL positivo $\rightarrow$ aceitar;

- $\quad$ Se TIR $=\mathrm{i} \rightarrow$ VPL nulo $\rightarrow$ indiferente;

- Se TIR $<\mathrm{i} \rightarrow$ VPL negativo $\rightarrow$ rejeitar. 
De forma inversa, para financiamentos tem-se:

- $\quad$ Se TIR $>\mathrm{i} \rightarrow$ VPL negativo $\rightarrow$ rejeitar;

- $\quad$ Se TIR $=\mathrm{i} \rightarrow$ VPL nulo $\rightarrow$ indiferente;

- Se TIR $<\mathrm{i} \rightarrow$ VPL positivo $\rightarrow$ aceitar.

\subsection{Comparação de Opções de Projeto em Termos de Custos}

A comparação de custos é utilizada quando existe a necessidade de tomar uma decisão dentre as diversas configurações que satisfazem os requisitos de um certo projeto. Jaluria (1998) descreve algumas metodologias que podem ser utilizadas nessa comparação e posterior tomada de decisão. Dentre essas metodologias, duas se apresentam como adequadas para o desenvolvimento do presente trabalho, e são descritas a seguir.

\subsubsection{Análise pelo Valor Presente (VP)}

Utilizada quando as diferentes alternativas apresentam o mesmo tempo de vida. Todos os custos e benefícios (economia, valores residuais da depreciação, etc.) de cada uma das possíveis configurações são trazidos para valores presentes pela Eq. (6.18), e a alternativa que apresentar o menor valor presente deverá ser escolhida.

$$
\mathrm{VP}=\mathrm{IT}+(\mathrm{CAT}-\mathrm{EC}-\mathrm{VR}) \times(\mathrm{P} / \mathrm{S}, \mathrm{i}, \mathrm{n})+\mathrm{CF} \times(\mathrm{P} / \mathrm{F}, \mathrm{i}, \mathrm{n} 1)
$$

onde EC é a economia anual de uma dada configuração em relação a um custo de referência (por exemplo na substituição de um insumo energético mais caro por um mais barato), VR é o valor de resgate ou de venda do equipamento no final da vida do projeto, e CF é o custo de eventuais reformas dos equipamentos ao longo da vida do projeto. 


\subsubsection{Análise da Economia de Ciclo de Vida (ECV)}

Esta metodologia permite determinar as condições sobre a qual uma alternativa é vantajosa com respeito de outra, para isso considera a diferença entre o valor presente dos custos de duas alternativas. A equação 6.23 descreve a expressão para a economia de ciclo de vida.

$$
\begin{aligned}
\mathrm{ECV}= & \left(\mathrm{IT}_{\mathrm{A}}-\mathrm{IT}_{\mathrm{B}}\right)+\left(\mathrm{CAT}_{\mathrm{A}}-\mathrm{CAT}_{\mathrm{A}}\right) \times(\mathrm{P} / \mathrm{S}, \mathrm{i}, \mathrm{n})+\left(\mathrm{CF}_{\mathrm{A}}-\mathrm{CF}_{\mathrm{B}}\right) \times\left(\mathrm{P} / \mathrm{F}, \mathrm{i}, \mathrm{n}_{1}\right) \\
& -\left(\mathrm{EC}_{\mathrm{A}}-\mathrm{EC}_{\mathrm{B}}\right) \times(\mathrm{P} / \mathrm{S}, \mathrm{i}, \mathrm{n})-\left(\mathrm{VR}_{\mathrm{A}}-\mathrm{VR}_{\mathrm{B}}\right) \times(\mathrm{P} / \mathrm{F}, \mathrm{i}, \mathrm{n})
\end{aligned}
$$

Jaluria (1998) ressalta que a preferência de uma alternativa com respeito de outra é função tanto da taxa de juros quanto do tempo de vida do projeto, portanto com a variação de ambos os parâmetros podem ser achados a taxa de retorno do investimento, assim como o tempo de retorno do investimento, sendo registrados graficamente.

Para a taxa de retorno do investimento é variada a taxa de juros e mantido constante o tempo de vida do projeto e para o tempo de retorno deverá ser feito o contrário (manter fixa a taxa de juros), os seus valores correspondem ao ponto em que a ECV se torna zero.

O valor positivo do ECV indicará que os custos da alternativa A são maiores e, portanto a alternativa deverá ser selecionada, ou seja, indicará que um melhor retorno será obtido com a alternativa $\mathrm{B}$, uma vez que a taxa de retorno é maior que a taxa de juros considerada. Além disso, indicará que o tempo de retorno é menor que o tempo de vida do projeto, com isso, a escolha da alternativa B é confirmada. 


\section{ANÁLISE DE CENÁRIOS}

\subsection{Introdução}

A inserção da tecnologia na produção de leite cru para atender às novas exigências do mercado tem sido limitada por dois fatores:

- a disponibilidade de energia elétrica, escassa em algumas regiões afastadas das redes de distribuição e de baixa qualidade em outras;

- a falta de capital por parte dos produtores, principalmente os de pequeno porte para a aquisição de equipamentos adequados.

Em relação ao primeiro fator, a utilização de recursos energéticos renováveis disponíveis na área rural, como o biogás, torna-se interessante pois sua produção resolve tanto o problema ambiental quanto o problema da disponibilidade de energia. Quanto à falta de capital, a implantação de um projeto de MDL pode gerar os recursos necessários para a modernização do processo produtivo.

Existem hoje no mercado empresas interessadas no desenvolvimento de projetos de MDL de pequena escala para a comercialização dos créditos de carbono, que se propõem assumir os custos da implantação do projeto MDL de pequena escala, deixando as tarefas de operação do biodigestor a cargo do produtor rural, que pode utilizar o biogás produzido. Além disso, uma parte dos recursos advindos da venda dos créditos de carbono gerados (tipicamente 10\%) é repassada pelas empresas para o produtor (SOUZA, 2005).

Assim, o presente trabalho analisa a situação de um produtor de médio porte, com um rebanho da ordem de 50 vacas, que já faz uso ou visa introduzir a tecnologia do resfriamento do leite com o intuito de atender às exigências de qualidade impostas pela legislação brasileira, bem como aumentar a produtividade, rentabilidade e 
competitividade de seu negócio, e que implantará, em conjunto com uma empresa, um projeto de MDL baseado em um biodigestor. São avaliados dois cenários para demonstrar quais as oportunidades de um determinado produtor viabilizar a implantação desse tipo de sistema e qual o resultado ou influência desse produtor ser inserido em um projeto MDL.

No cenário 1 é considerado que o produtor não conta com um resfriador de leite, e assim são avaliados sistemas utilizando diversas fontes de energia. No cenário 2 é avaliada a viabilidade de substituir o consumo de energia elétrica comprada da rede (onde ela está disponível) por energia gerada a partir do biogás para operação de um tanque resfriador por expansão, já instalado e operando na fazenda.

O estudo proposto inicia-se com o cálculo da carga térmica de refrigeração que o sistema de resfriamento deve atender, a quantificação da redução de emissões, posteriormente é dimensionada capacidade necessária do biodigestor e finalmente são avaliados os cenários considerados.

\subsection{Dimensionamento do Sistema de Resfriamento de Leite}

O sistema de refrigeração a ser selecionado deve atender à demanda térmica de resfriamento e conservação do leite produzido pelas 50 vacas leiteiras em duas ordenhas por dia, sendo a primeira no período de manhã e a outra à tarde. Considerase que os volumes de leite produzidos em cada ordenha são os mesmos, podendo atingir um pico de $60 \%$ na ordenha da manhã e $40 \%$ na da tarde. Cada vaca produz, em média, 20 litros/dia de leite no total das duas ordenhas, e dessa forma a produção diária de leite será de 1.000 litros/dia.

A coleta do leite na fazenda será realizada a cada dois dias (48 horas), o que significa que o sistema deve ter a capacidade para armazenar e conservar o leite de 4 ordenhas (2.000 litros). O período de 48 horas entre coletas é função da Instrução Normativa 51 (IN51). 
Levando em conta que uma vaca produtora passa por uma fase de "seca" de aproximadamente 60 dias, que começa no final da gestação e acaba no início da lactação (produção de leite para amamentar as crias), cada vaca produzirá leite 305 dias ao ano, e dessa forma a produção anual de leite (período de lactação) será de 305.000 litros para as 50 vacas consideradas.

\subsubsection{Carga Térmica do Leite}

O sistema de resfriamento de leite deverá cumprir duas funções: a de resfriamento e a de conservação do leite, como descrito anteriormente. Em relação ao resfriamento, a IN51, estabelece que o "Leite Cru Refrigerado Tipo B", deve ter sua temperatura reduzida desde a temperatura de ordenha $\left(35-36^{\circ} \mathrm{C}\right)$ até $4^{\circ} \mathrm{C}$ em no máximo três horas após a ordenha.

Em função das considerações feitas nos itens anteriores e do estipulado na legislação (IN53), para o resfriamento desse volume de leite será necessário um tanque de resfriamento de código 4BII (ver anexo B). Os fabricantes, em função da legislação, costumam considerar uma capacidade frigorífica padrão para o dimensionamento desse equipamento (500 litros em cada uma das ordenhas), que deverá ser suficiente para resfriar o $25 \%$ do volume total de leite (500 litros neste caso) em menos de 3 horas.

Dessa forma, considerando os ganhos de calor devidos ao produto (leite cru) e à transmissão de calor pelas paredes/isolamento do tanque, calcula-se a carga térmica que deverá ser atendida pela unidade resfriadora. Os ganhos de calor devido ao agitador, necessário para manter a adequada homogeneidade do leite, podem ser considerados desprezíveis, uma vez que o mesmo atuará num esquema típico de 2 minutos de operação a cada 15 minutos, e com uma velocidade reduzida.

O ganho de calor devido ao produto é dado por:

$$
\dot{\mathrm{Q}}_{\text {ordenha }}=\frac{\left(\mathrm{V}_{\text {ordenha }} \times \rho_{\text {leite }}\right)}{\Delta \mathrm{t}} \times \mathrm{c}_{\text {leite }} \times\left(\mathrm{T}_{\mathrm{i}, \text { leite }}-\mathrm{T}_{\mathrm{f}, \text { leite }}\right)
$$


onde $c_{\text {leite }}$ é o calor específico do leite $(3,94 \mathrm{~kJ} / \mathrm{kg} . \mathrm{K})$ e $\rho_{\text {leite }}$ a sua massa específica $(1,034 \mathrm{~kg} / \mathrm{l}) . \mathrm{T}_{\mathrm{i}, \text { leite }}$ e $\mathrm{T}_{\mathrm{f}, \text { leite }}$ são as temperaturas inicial $\left(35^{\circ} \mathrm{C}\right)$ e final $\left(4^{\circ} \mathrm{C}\right)$ do leite, $\Delta$ t o tempo máximo de resfriamento (3 horas), e $\mathrm{V}_{\text {ordenha }}$ é o volume de leite produzido numa dada ordenha.

Para a demanda frigorífica padrão, correspondente a 500 litros, tem-se:

$$
\begin{gathered}
\dot{\mathrm{Q}}_{\text {ordenha-padrão }}=\frac{(500 \times 1,034)}{3 \times 3600} \times 3,94 \times(35-4) \\
\dot{\mathrm{Q}}_{\text {ordenha-padrão }}=5,85 \mathrm{~kW}
\end{gathered}
$$

Considerando um pico máximo de produção de $60 \%$ na ordenha de manhã, é estimada qual a demanda frigorífica de pico para esse volume (600 litros). Assim, tem-se:

$$
\begin{gathered}
\dot{\mathrm{Q}}_{\text {ordenha-manh̃̃ }}=\frac{(600 \times 1,034)}{3 \times 3600} \times 3,94 \times(35-4) \\
\dot{\mathrm{Q}}_{\text {ordenha-manhã }}=7,02 \mathrm{~kW}
\end{gathered}
$$

O ganho de calor por transmissão do tanque de resfriamento deve ser tal que o aumento de temperatura não deve exceder a $1^{\circ} \mathrm{C}$ em um período de 4 horas sem atuação do sistema de refrigeração, considerando o tanque no nível máximo (2000 litros), conforme a IN 53. Assim, na pior situação este ganho por transmissão será menor ou igual a $0,57 \mathrm{~kW}$, que é uma parcela praticamente desprezível em relação aos ganhos devido ao produto. 
Assim, a capacidade nominal necessária da unidade de resfriamento é de 5,85 $\mathrm{kW}$, e a eventual carga térmica de pico, considerando um volume máximo de 600 litros é de 7,02 kW, que pode ser manejada com um maior tempo de operação da unidade frigorífica, ligando-a antes de terminar a ordenha para garantir o cumprimento da norma (tempo de resfriamento de até três horas após o fim da ordenha).

\subsection{Quantificação das Emissões de GEE e dos Créditos de Carbono Gerados}

Para a quantificação dos GEE alguns conceitos precisam ser definidos:

- Atividade do projeto de MDL (project activity): é a atividade cujo desenvolvimento permitirá reduzir a emissão de GEE de determinado empreendimento (configuração alternativa).

- Configuração de referência (baseline): é o cenário que representa as emissões/remoções de GEE que ocorreriam na ausência do projeto.

- Adicionalidade: a atividade de um projeto de MDL é considerada adicional se as emissões antrópicas de $\mathrm{CO}_{2}$ equivalente forem menores do que as que ocorreriam na ausência do projeto.

Maiores detalhes podem ser consultados nas metodologias AM0006 e AM0016, disponíveis no site do Conselho Executivo do MDL ${ }^{6}$.

\subsubsection{Gerenciamento do Esterco}

Considerando uma fazenda com 50 vacas adultas (maduras), criadas em regime de confinamento com alimentação razoável, um índice de gravidez de $80 \%$ e os parâmetros indicados na Tab. 7.1, as emissões de GEE serão quantificadas conforme o procedimento descrito no Capítulo 5, admitindo para o Brasil uma situação semelhante à dos Estados Unidos e Europa, em função da característica nacional de especialização na produção de leite.

\footnotetext{
${ }^{6}$ Disponível em: http://cdm.unfccc.int/methodologies
} 


\subsubsection{Emissões de Metano}

- Energia Bruta

$$
\begin{gathered}
\mathrm{EN}_{\mathrm{m}}=0,335 \mathrm{~m}_{\text {vaca }}^{0,75}=0,335.600^{0,75}=40,6 \mathrm{MJ} /(\text { vaca.dia }) \\
\mathrm{EN}_{1}=20 \times(1,47+0,4 \times 4)=61,4 \mathrm{MJ} / \mathrm{Vaca} \times \text { dia } \\
\mathrm{EN}_{\mathrm{gr}}=0,075 .(40,61)=3,05 \mathrm{MJ} / \mathrm{Vaca} \times \mathrm{dia} \\
\mathrm{EN}_{/ \mathrm{ED}}=0,298+(0,00355 \times 65)=0,52875 \\
\mathrm{EN}_{\mathrm{cr} / \mathrm{ED}}=-0,036+(0,00535 \times 65)=0,3118
\end{gathered}
$$

Tabela 7.1. Parâmetros para o cálculo da emissão de metano

\begin{tabular}{cc}
\hline Parâmetro & Valor \\
\hline Digestibilidade (ED) & $65 \%$ \\
Taxa de conversão de metano $\left(\mathrm{TC}_{\mathrm{CH} 4}\right)$ & $6 \%$ \\
Produção de leite $\left(\mathrm{m}_{\text {leite }}\right)$ & $20 \mathrm{~kg} / \mathrm{dia}$ \\
Teor de gordura do leite $\left(\mathrm{TG}_{\text {leite }}\right)$ & $4 \%$ \\
Peso do animal $\left(\mathrm{m}_{\text {vaca }}\right)$ & $600 \mathrm{~kg}$ \\
Peso acumulado no crescimento $\left(\mathrm{m}_{\mathrm{g}}\right)$ & $0($ animais adultos $)$ \\
Conteúdo de cinzas $(\mathrm{CCI})$ & $8 \%$ \\
Taxa de prenhez & $80 \%$ \\
Potencial de produção de metano $(\mathrm{BO})$ & $0,24 \mathrm{~m}^{3} / \mathrm{kg}_{\mathrm{Sv}}$ \\
\hline
\end{tabular}


A energia para crescimento $\left(\mathrm{EN}_{\mathrm{cr}}\right)$ é zero por conta que a vaca madura não ganha peso.

$$
\begin{gathered}
\mathrm{EB}=\frac{\left[(40,61+0+61,4)+\frac{80}{100} \times 3,05\right] \times\left(\frac{100}{65}\right)}{0,5288+\left(\frac{0}{0,3118}\right)} \\
\mathrm{EB}=197,52 \mathrm{MJ} / \text { vaca } \times \text { dia }
\end{gathered}
$$

- Sólidos Voláteis

$$
\begin{gathered}
\mathrm{SV}=197,52 \times \frac{1 \mathrm{~kg}_{\mathrm{ms}}}{18,45 \mathrm{MJ}} \times\left(1-\frac{65}{100}\right) \times\left(1-\frac{8}{100}\right) \\
\mathrm{SV}=3,45 \mathrm{~kg} / \text { vaca } \times \text { dia }
\end{gathered}
$$

- Fatores de Emissão das Configurações

Para a emissão total de metano, de acordo com o item 5.5.1.2, foi selecionada uma lagoa anaeróbica (SGEA-1) como configuração de referência, por ser comumente utilizada como solução ao acúmulo progressivo de dejetos no estábulo e para o aprimoramento das operações de limpeza do estábulo por lavagem, porém grande poluidora (Fig. 7.1). 


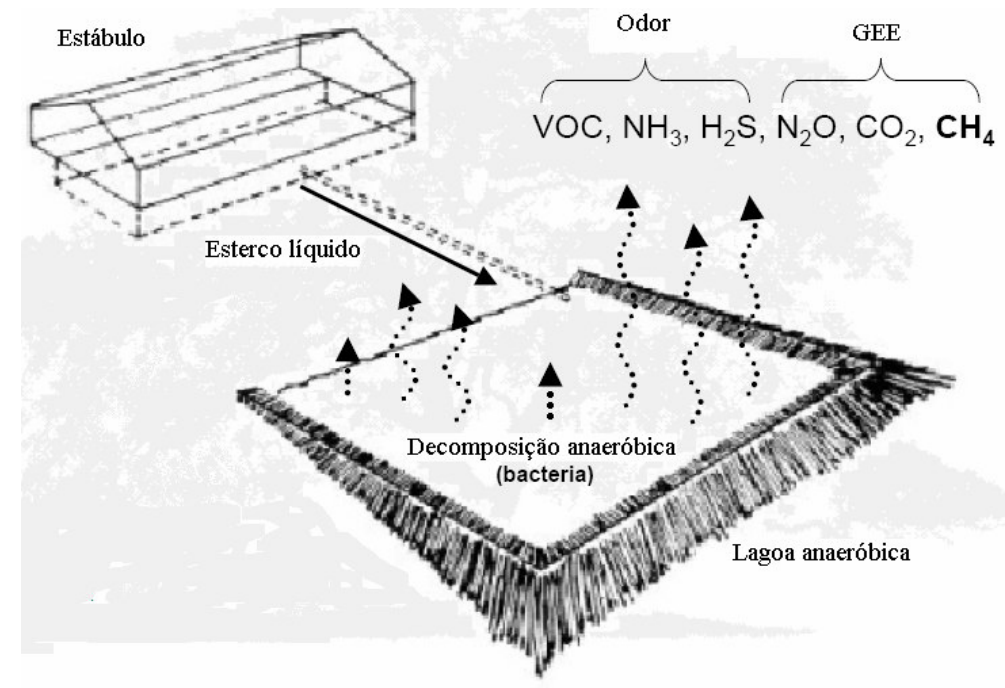

Figura 7.1. Gerenciamento do esterco por lagoa anaeróbica

Fonte: Jensen (2006)

Segundo o IPCC (1996), essa configuração apresenta um fator de conversão de metano (FCM) de 90\%, e assim o fator de emissão é:

$$
\begin{gathered}
\mathrm{FE}_{\mathrm{CH}_{4}}=365 \times\left[0,24 \times 3,45 \times\left(\frac{100}{100} \times \frac{90}{100}\right)\right] \times 0,718 \\
\mathrm{FE}_{\mathrm{CH}_{4}}=365 \times 0,535 \mathrm{~kg} / \text { vaca } \times \text { dia } \\
\mathrm{FE}_{\mathrm{CH}_{4}}=195,28 \mathrm{~kg} / \mathrm{vaca} \times \text { ano }
\end{gathered}
$$

O biodigestor a instalar, representa a configuração alternativa (SGEA-2), a que permitira reduzir as emissões próprias da lagoa anaeróbica (Fig. 7.1). 


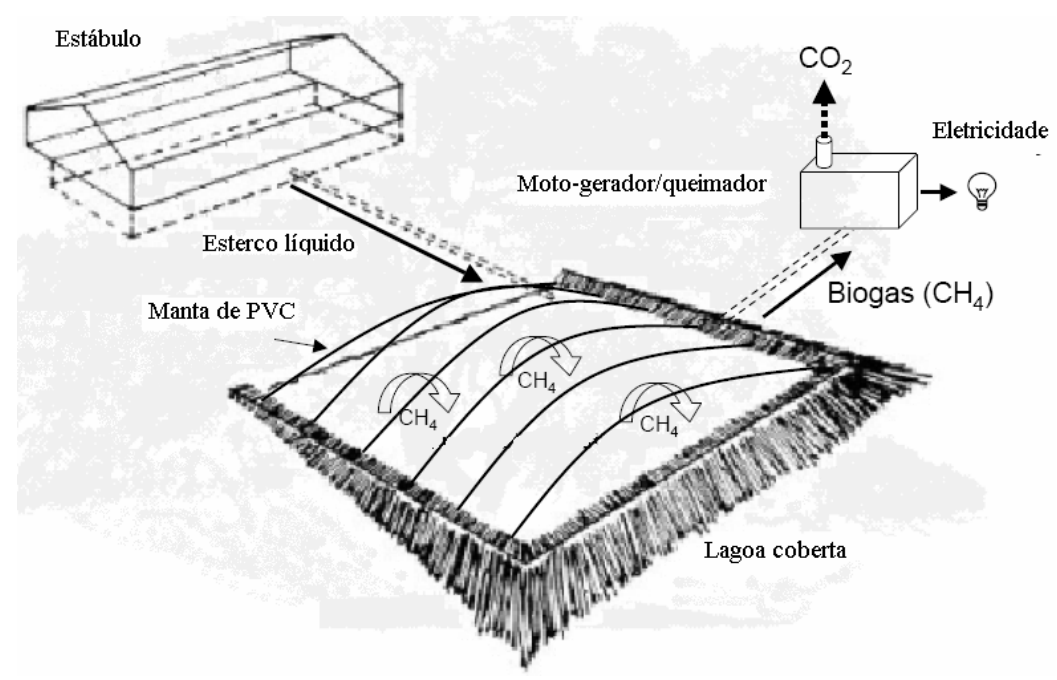

Figura 7.2. Gerenciamento do esterco por biodigestor.

Fonte: Jensen (2006)

Esse sistema de gerenciamento de esterco apresenta um FCM de 5 a $10 \%$ (IPCC, 1996). Assim, considerando o valor mínimo de 5\%:

$$
\begin{gathered}
\mathrm{FE}_{\mathrm{CH}_{4}}=365 \times\left[0,24 \times 3,45 \times\left(\frac{100}{100} \times \frac{5}{100}\right)\right] \times 0,718 \\
\mathrm{FE}_{\mathrm{CH}_{4}}=365 \times 0,02972 \mathrm{~kg} / \mathrm{vaca} \times \mathrm{dia} \\
\mathrm{FE}_{\mathrm{CH}_{4}}=10,84 \mathrm{~kg} / \mathrm{vaca} \times \text { ano }
\end{gathered}
$$


- Emissões Totais Equivalentes das configurações

\section{- Configuração de Referência:}

$$
\begin{aligned}
\mathrm{ET}_{\mathrm{CH}_{4}} & =(195,28 \times 50) \times \frac{21}{1000} \\
\mathrm{ET}_{\mathrm{CH}_{4}} & =205,04^{\text {ton }_{\mathrm{CO}_{2} \text {-equiv }} / \text { ano }}
\end{aligned}
$$

\section{- Configuração Alternativa:}

$$
\begin{aligned}
& \mathrm{ET}_{\mathrm{CH}_{4}}=(10,84 \times 50) \times \frac{21}{1000} \\
& \mathrm{ET}_{\mathrm{CH}_{4}}=11,38^{\text {ton }_{\mathrm{CO}_{2} \text {-equiv }} / \text { ano }}
\end{aligned}
$$

É importante destacar que, para efeitos de redução das emissões de GEE, não se considera as emissões devidas à fermentação entérica uma vez que elas não são condicionadas pelo tipo de sistema de gerenciamento de esterco. Apenas como ilustração, para o presente caso as emissões por fermentação entérica são da ordem de 82 toneladas equivalentes de $\mathrm{CO}_{2}$.

\subsubsection{Emissão de Óxido Nitroso $\left(\mathrm{N}_{2} \mathrm{O}\right)$}

Para o calculo das emissões diretas de $\mathrm{N}_{2} \mathrm{O}$, da mesma forma que no caso das emissões de metano, são consideradas tanto a lagoa anaeróbica e o biodigestor. As 
emissões indiretas não são consideradas pois seriam iguais em ambos os SGEA (disposição no campo da matéria orgânica resultante).

\section{- Configuração de Referência:}

Nex $=100$ kg/animal.ano (Tab. 5.3)

$\mathrm{FE}_{\mathrm{SGEA}}=0,002 \mathrm{~kg}_{\mathrm{N} 2 \mathrm{O}-\mathrm{N}} / \mathrm{kg}_{\mathrm{N}}(\mathrm{Tab} .5 .4)$

Assim

$$
\begin{gathered}
\mathrm{FE}_{\mathrm{N}_{2} \mathrm{O}}=100 \times \frac{100}{100} \times 0,002 \times \frac{44}{28} \\
\mathrm{FE}_{\mathrm{N}_{2} \mathrm{O}}=0,314 \mathrm{~kg}_{\mathrm{N}_{2} \mathrm{O}} / \text { vaca } \times \text { ano } \\
\mathrm{ET}_{\mathrm{N}_{2} \mathrm{O}}=0,314 \times 50 \times \frac{310}{1000} \\
\mathrm{ET}_{\mathrm{N}_{2} \mathrm{O}}=4,87^{\text {ton }_{\mathrm{CO}_{2} \text {-equiv }} / \text { ano }}
\end{gathered}
$$

\section{- Configuração Alternativa:}

A emissão de oxido nitroso de um biodigestor (sistemas de gerenciamento de esterco) pode ser considerada nula (IPCC, 1996). Portanto: 


$$
\mathrm{ET}_{\mathrm{N}_{2} \mathrm{O}}=0
$$

\subsubsection{Quantificação da Emissão de GEE na Utilização do Biogás}

No caso da utilização de um biodigestor como SGEA, tem-se uma emissão adicional pelo "uso" do biogás gerado, que deve ser queimado. Segundo Murphy et al. (2003), o fator de emissão equivalente da queima do biogás é de 1,96 $\mathrm{kg}_{\mathrm{CO} 2 \text {-equiv }} / \mathrm{m}^{3}$.

Considerando que é recuperado biogás com um conteúdo de $65 \%$ de $\mathrm{CH}_{4}$ e 35 $\mathrm{CO}_{2}$, calcula-se a vazão volumétrica de biogás disponível:

$$
\begin{gathered}
\dot{\mathrm{V}}_{\text {biogás }}=\frac{\left(\mathrm{FE}_{\mathrm{CH}_{4}-\mathrm{CR}}-\mathrm{FE}_{\mathrm{CH}_{4}-\mathrm{PR}}\right)}{\rho_{\mathrm{CH}_{4}}} \times\left(\frac{100}{\% \mathrm{CH}_{4}}\right) \\
\dot{\mathrm{V}}_{\text {biogás }}=\frac{(0,535-0,029)}{0,718} \times \frac{100}{65} \\
\dot{\mathrm{V}}_{\text {biogás }}=1,08 \mathrm{~m}^{3} / \text { vaca.dia }
\end{gathered}
$$

As 50 vacas consideradas produzirão aproximadamente $50 \mathrm{~m}^{3}$ de biogás por dia no biodigestor e estará disponível para sua queima.

A emissão total de $\mathrm{CO}_{2}$ associado com a queima do biogás recuperado é:

$$
\mathrm{ET}_{\text {queima }}=\frac{365 \times(50 \times 1,96)}{1000}
$$




$$
\mathrm{ET}_{\text {queima }}=35,77^{\text {ton }_{\mathrm{CO}_{2}-\text { equiv }}} / \text { ano }
$$

\subsubsection{Emissão Total e Redução Líquida de GEE}

Quantificada as emissões de cada um dos GEE para a configuração de referência (lagoa anaeróbica) e da configuração alternativa (biodigestor), tem-se:

$$
\begin{gathered}
\mathrm{ET}_{\mathrm{CR}}=205,04+4,87 \\
\mathrm{ET}_{\mathrm{CR}}=209,91^{\text {ton }_{\mathrm{CO}_{2} \text {-equiv }} / \text { ano }} \\
\mathrm{ET}_{\mathrm{PR}}=11,38+0+35,77 \\
\mathrm{ET}_{\mathrm{PR}}=47,15^{\text {ton }} \mathrm{CO}_{2} \text {-equiv } / \text { ano }
\end{gathered}
$$

Dessa forma, a redução líquida que será obtida com a implantação de um biodigestor é:

$$
\begin{gathered}
\mathrm{RE}=\mathrm{ET}_{\mathrm{CR}}-\mathrm{ET}_{\text {projeto }} \\
\mathrm{RE}=209,91-47,15 \\
\mathrm{RE}=162,76 \approx 163^{\text {ton }} \mathrm{CO}_{2} \text {-equiv } / \text { ano }
\end{gathered}
$$


Considerando um tempo de vida do projeto MDL de 10 anos, a redução de emissões correspondente à instalação de um biodigestor, geraria 1.630 créditos de carbono, e para um valor aproximado, no mercado europeu, de $€ 10,00$ ou $\mathrm{R} \$ 27,80$ por crédito de carbono (GAMEZ, 2006; ECONERGY, 2006), o ganho por venda desses créditos representaria uma receita total de $\mathrm{R} \$ 45.314$. Esse ganho é dividido entre o produtor (10\%) e a empresa financiadora do projeto (90\%).

\subsection{Sistema de Produção de Biogás - O Biodigestor}

Diversos autores apontam que o biodigestor de campânula de membrana plástica (lagoa coberta) apresenta o menor custo de investimento. Entre eles, Higham (1998) afirma que o custo por unidade de volume de biodigestor de campânula representa de 20 a $40 \%$ do custo de um biodigestor "tradicional" (alvenaria, aquecidos, misturados, etc.).

Já Perdomo e Oliveira (2000) consideram um custo aproximado de R \$150,00 por $\mathrm{m}^{3}$ de câmara de digestão para um biodigestor com base em alvenaria retangular com gasômetro de manta flexível de PVC. Quando considerado um biodigestor de fluxo ascendente, esse custo se eleva para $\mathrm{R} \$ 210,00$ por $\mathrm{m}^{3}$ construído (EMBRAPA, 2006).

Em função disso, para esse trabalho será selecionado um biodigestor do tipo campânula, com base nos cálculos apresentados a seguir.

\subsubsection{Dimensionamento}

A massa de afluente (mistura de esterco e água) que será introduzida diariamente no biodigestor é dada por:

$$
\dot{\mathrm{m}}_{\text {afluente }}=\dot{\mathrm{m}}_{\text {esterco }}+\dot{\mathrm{m}}_{\text {agua }}
$$


onde

$$
\dot{\mathrm{m}}_{\text {água }}=\dot{\mathrm{m}}_{\text {esterco }}=\frac{\dot{\mathrm{m}}_{\text {biogás }}}{\mathrm{FP}_{\text {biogás }}} \times \mathrm{n}_{\text {vacas }}
$$

Considerando um fator de produção de biogás ( $\left.\mathrm{FP}_{\text {biogás }}\right)$ de 0,0372 $\mathrm{m}^{3}$ biogás $/ \mathrm{kg}_{\text {esterco }}$ (VERASTEGUI e MATERO, 1979), determinou-se uma produção de esterco fresco de $27 \mathrm{~kg} / \mathrm{dia} / \mathrm{vaca}$ (cerca de 5\% do peso da vaca). Para os 50 animais, tem-se uma produção de $1.350 \mathrm{~kg}$ de esterco que com os $1.350 \mathrm{~kg}$ de água necessários para propiciar condições adequadas ao processo de fermentação, formam uma mistura de $2.700 \mathrm{~kg}$ que será introduzida no biodigestor a cada dia.

Em termos de volume, considerando-se a massa específica da mistura da ordem de $1.000 \mathrm{~kg} / \mathrm{m}^{3}$, teremos $2,7 \mathrm{~m}^{3} / \mathrm{dia}$. A partir desse volume é determinado o volume da câmara de digestão $\left(\mathrm{V}_{\mathrm{cd}}\right)$ por:

$$
\mathrm{V}_{\mathrm{cd}}=\mathrm{V}_{\text {afluente }} \times \mathrm{TRH}
$$

onde o tempo de retenção hidráulica (TRH) varia de 20 a 55 dias, dependendo do conteúdo orgânico dos detritos e da eficácia do biodigestor utilizado. Nesse trabalho está sendo adotado um TRH de 55 dias, e para os $2,7 \mathrm{~m}^{3}$ de matéria orgânica por dia, o volume da câmara de digestão deve ser da ordem de $149 \mathrm{~m}^{3}$.

O volume total do biodigestor é dado pela soma dos volumes da câmara de digestão e da câmara de armazenamento de biogás (gasômetro). Normalmente o volume da câmara de digestão representa $70 \%$ do volume total do biodigestor e, portanto, o volume total do biodigestor e da câmara de armazenamento de biogás serão de 149 e $63 \mathrm{~m}^{3}$, respectivamente. 
Uma vez definido o volume necessário, foi selecionado um biodigestor tubular de manta PVC, cuja base é constituída por uma fossa recoberta com manta PVC e apresenta um custo de investimento aproximado de $\mathrm{R} \$ 120,00$ por $\mathrm{m}^{3}$ de câmara de digestão (incluindo a fossa). As principais características de construção, operação e produção de biogás são mostradas na Tab. 7.2 e Fig. 3.4.

Na Tab. 7.3 é mostrada uma aproximação das características do biogás que será produzido no biodigestor selecionado.

Tabela 7.2. Ficha técnica do biodigestor selecionado.

\begin{tabular}{cc}
\hline Dado & Valor \\
\hline Diâmetro $(\mathrm{m})$ & 3,0 \\
Comprimento $(\mathrm{m})$ & 29 \\
Volume do biodigestor $\left(\mathrm{m}^{3}\right)$ & 212 \\
Câmara de digestão $\left(\mathrm{m}^{3}\right)$ & 149 \\
Reservatório de biogás $\left(\mathrm{m}^{3}\right)$ & 63 \\
Área de manta PVC $\left(\mathrm{m}^{2}\right)$ & 317 \\
Tempo de vida do biodigestor $($ anos $)$ & 15 \\
Investimento total no biodigestor $(\mathrm{R} \$)$ & 14.600 \\
\hline
\end{tabular}

Tabela 7.3. Principais características do biogás considerado.

\begin{tabular}{cc}
\hline Descrição & Valor \\
\hline $\mathrm{CH}_{4}$ & $65 \%$ \\
$\mathrm{CO}_{2}$ & $\approx 35 \%$ \\
$\mathrm{H}_{2} \mathrm{~S}$ & $\approx 1000 \mathrm{ppm}$ \\
$\rho\left(\mathrm{kg} / \mathrm{m}^{3}\right)$ & 1,2 \\
$\mathrm{PCI}\left(\mathrm{kJ} / \mathrm{m}^{3}\right)$ & 23.100 \\
\hline
\end{tabular}

\subsubsection{Uso do Biogás na Geração de Potência}

Esta quantidade de biogás é suficiente para acionar um MCI de ciclo Otto de $8,0 \mathrm{~kW}$ por cerca de 10,45 horas/dia, considerando um biogás descrito na Tab. 7.3, uma eficiência do motor da ordem de $26 \%$ e um consumo específico do motor de 0,6 
m³/kWh (WERNER et al., 1989). A Tab. 7.4 apresenta outros tempos de operação em função da potência do motor.

Tabela 7.4. Tempo de operação em função da potência do MCI.

\begin{tabular}{lcccccc}
\hline $\mathrm{W}_{\text {motor }}(\mathrm{kW})$ & 56,00 & 23,00 & 19,00 & 15,00 & 11,00 & 8,00 \\
$\mathrm{t}_{\text {oper }}(\mathrm{h} / \mathrm{dia})$ & 1,49 & 3,64 & 4,41 & 5,58 & 7,61 & 10,46 \\
\hline
\end{tabular}

\subsection{Análise dos Cenários}

\subsubsection{Cenário 1}

Como comentado anteriormente, nesse cenário é analisada qual a melhor configuração para instalação de um sistema de resfriamento de leite em uma fazenda leiteira que ainda não conta com um equipamento desse tipo. Assim, é desenvolvida uma análise técnico-econômica de algumas configurações adequadas para atender à demanda térmica do leite (resfriamento) calculada no item 7.2. Serão analisadas as seguintes configurações:

- Configuração $\mathrm{N}^{\circ}$ 01: um tanque de resfriamento com unidade condensadora por compressão de vapor, acionada por energia elétrica comprada da rede de distribuição, quando disponível;

- Configuração $\mathrm{N}^{\circ}$ 02: a mesma configuração anterior, com a energia elétrica sendo gerada a partir de biogás em um moto-gerador de ciclo Otto;

- Configuração $\mathrm{N}^{\circ}$ 03: a mesma configuração anterior, utilizando uma mistura biogás-diesel queimada em um moto-gerador de ciclo Diesel;

- Configuração $\mathrm{N}^{\circ}$ 04: um tanque de resfriamento com unidade condensadora por absorção com queima direta de biogás. 
É importante destacar que o biogás está sendo produzido em um biodigestor instalado por um projeto MDL de pequena escala, em parceria entre o produtor e uma empresa que negociará os créditos de carbono gerados, e que por isso esse insumo energético tem custo zero para o produtor, pois se trata da utilização de um insumo que seria queimado sem aproveitamento.

Foi considerado um biogás com um conteúdo de $\mathrm{H}_{2} \mathrm{~S}$ menor a 1000 ppm, portanto, não é considerado um sistema de remoção de $\mathrm{H}_{2} \mathrm{~S}$ (CHAMBERS e POTTERS, 2002). Dessa forma o biogás pode ser utilizado diretamente do biodigestor.

\subsubsection{Configuração $\mathrm{N}^{\circ} 01$}

Nesta configuração tem-se um tanque de conservação e uma unidade condensadora por compressão de vapor (UCCV) acionada por energia elétrica comprada da rede de distribuição (Fig. 7.3).

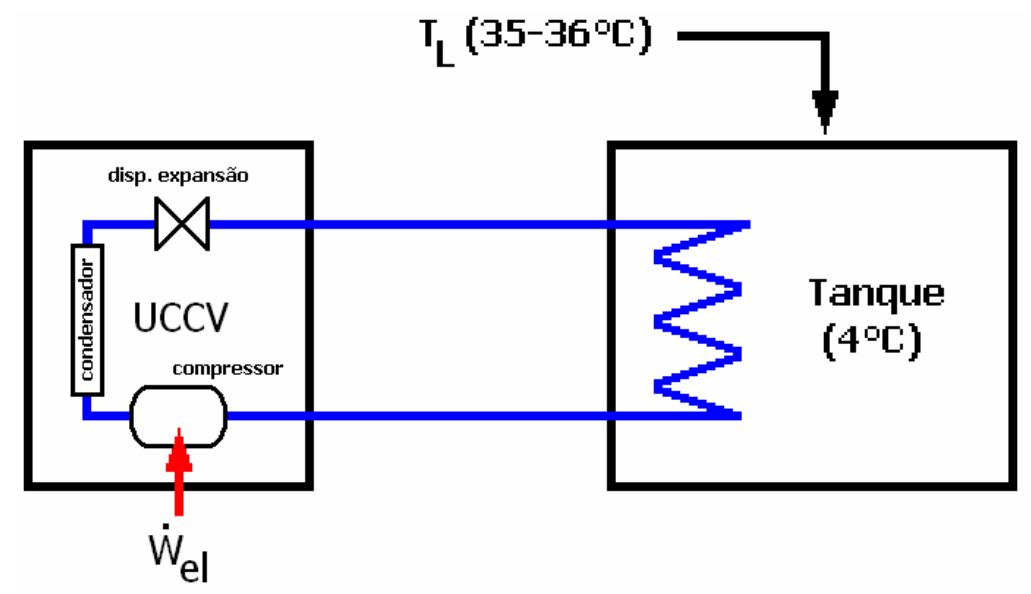

Figura 7.3. Unidade condensadora por compressão de vapor e tanque de resfriamento. 


\section{- Seleção do Equipamento}

A partir dos cálculos de demanda nominal de carga térmica de refrigeração, foi selecionado o equipamento cujas características estão listadas na Tab. 7.5.

Tabela 7.5. Tanque de resfriamento de leite selecionado.

\begin{tabular}{ccc}
\hline Componente & Característica & Valor \\
\hline \multirow{2}{*}{ Tanque } & Volume nominal (litros) & 2000 \\
& Ordenhas por dia & 4 \\
& Isolamento & Poliuretano injetado \\
\hline & Material & Aço inoxidável \\
Unidade & Tipo & Expansão direta \\
condensadora & Acionamento & Elétrico \\
& Compressor & Hermético \\
& Capacidade frigorífica nominal $(\mathrm{kW})$ & 6,25 \\
& Refrigerante & R-22 \\
& Sistema de redução de torque de partida & sim \\
\hline & (pressostato + válvula solenóide) & $17.692,00$ \\
\hline
\end{tabular}

\section{- Custos de Operação e Manutenção}

Os cálculos a seguir, simulando a pior situação, estão baseados no atendimento da demanda frigorífica de pico, correspondente aos $60 \%$ do leite produzido na ordenha de manhã (600 1) e 40\% à tarde (400 1). Dessa forma, são avaliados os tempos de operação da unidade com relação à capacidade frigorífica nominal do equipamento selecionado $(6,25 \mathrm{~kW})$.

Para avaliação do consumo de energia, será considerado que o sistema esteja trabalhando a plena carga. A operação do sistema pode ser dividida em três etapas:

- Etapa de resfriamento

A etapa de refrigeração corresponde ao resfriamento do leite vindo do estábulo logo após a ordenha. 
Considerando o tempo necessário para resfriamento por ordenha e a potência total da unidade condensadora, o consumo $(\mathrm{kWh} / \mathrm{dia})$ será de:

$$
\mathrm{W}_{\text {resf }}=\dot{\mathrm{W}}_{\text {total }} \cdot \mathrm{t}_{\text {resf }}=\left(\dot{\mathrm{W}}_{\text {comp }}+\dot{\mathrm{W}}_{\text {vent }}+\dot{\mathrm{W}}_{\text {agit }}\right) \cdot\left(\mathrm{t}_{\text {resf,manhã }}+\mathrm{t}_{\text {resf, tarde }}\right)(7.27)
$$

O tempo de resfriamento para a situação considerada (Tab. 7.6) é determinado por relação direta com a capacidade frigorífica da unidade selecionada (Eq. 7.28).

Tabela 7.6. Tanque de resfriamento de leite selecionado

\begin{tabular}{ccc}
\hline $\begin{array}{c}\text { Volume de leite } \\
(\mathrm{l})\end{array}$ & $\begin{array}{c}\text { Capacidade frigorífica } \\
(\mathrm{kW})\end{array}$ & $\begin{array}{c}\text { Tempo de resfriamento } \\
(\mathrm{h})\end{array}$ \\
\hline 400 & 4,68 & 2,25 \\
500 & 6,25 & 2,71 \\
600 & 7,02 & 3,37 \\
\hline & \\
& \\
& $\mathrm{t}_{\text {resf }}=\frac{\mathrm{t}_{\text {padrão }} \times \dot{\mathrm{Q}}_{\text {ordenha-manhã }}}{\dot{\mathrm{Q}}_{\text {padrão }}}$
\end{tabular}

Para um tempo de operação de 5,62 horas por dia (3,37 horas de manhã e 2,25 horas à tarde), uma potência total de $2,84 \mathrm{~kW}$, o sistema de refrigeração consome $15,96 \mathrm{kWh} / \mathrm{dia}$.

- Etapa de conservação

Esta corresponde a etapa em que a unidade resfriadora entra em operação para conservar o leite a $4^{\circ} \mathrm{C}$. O consumo depende do tamanho do ventilador e compressor, assim como a periodicidade e tempo de operação. 


$$
\mathrm{W}_{\text {conserv }}=\dot{\mathrm{W}}_{\text {total }} \cdot \mathrm{t}_{\text {conserv }}=\left(\dot{\mathrm{W}}_{\text {comp }}+\dot{\mathrm{W}}_{\mathrm{vent}}+\dot{\mathrm{W}}_{\text {agit }}\right) \cdot \mathrm{t}_{\text {conserv }}
$$

O tempo de operação é calculado em 3 fases, na primeira é determinado o tempo que o volume (600 e 1000 no primeiro dia, e 1600 e 2000 no segundo dia) do tanque tarda em ganhar $1^{\circ} \mathrm{C}$, com uma taxa de absorção de calor máxima de $0,57 \mathrm{~kW}$ ( $\left.\mathrm{t}_{\text {conserv, }}\right)$. Assim determina-se o número de vezes ( $\left.\mathrm{n}_{\text {conserv }}\right)$ que esse ganho de calor é atingido no período entre o final de uma etapa de resfriamento e o começo da seguinte (9 horas). A seguir é determinado o tempo $\left(\mathrm{t}_{\text {conserv, }, 2}\right)$ que o equipamento leva para retirar esse ganho de calor, considerando sua capacidade frigorífica nominal ( $\left.Q_{U C C V}\right)$. Finalmente o tempo de operação diário ( $\mathrm{t}_{\text {conserv }}$ ) é determinado, conforme:

$$
\begin{gathered}
\mathrm{t}_{\text {conserv }, 1}=\frac{\mathrm{m}_{\text {leite }} \mathrm{c}_{\text {leite }} \Delta \mathrm{T}}{\dot{\mathrm{Q}}_{\text {transmissão }}} \\
\mathrm{n}_{\text {conserv }}=\frac{\text { período }_{\text {ordenha }}}{\mathrm{t}_{\text {conserv }, 1}} \\
\mathrm{t}_{\text {conserv }, 2}=\frac{\mathrm{m}_{\text {leite }} \mathrm{c}_{\text {leite }} \Delta \mathrm{T}}{\dot{\mathrm{Q}}_{\mathrm{UCCV}}} \\
\mathrm{t}_{\text {conserv }}=\sum\left(\mathrm{n}_{\text {conserv }} \mathrm{t}_{\text {conserv }, 2}\right)
\end{gathered}
$$

Para o caso em estudo, determina-se que o tanque opera 1,85 e 0,87 horas no primeiro e segundo dia de armazenamento, respectivamente, o que representa uma operação média diária de 1,36 horas, e assim seriam consumidos 3,86 kWh/dia. 
- Etapa de agitação

Nesta etapa o leite é mantido homogeneizado mediante um agitador mecânico, cujo consumo depende da potência, da periodicidade e tempo de operação (Eq. 7.34).

$$
\mathrm{W}_{\text {agit }}=\dot{\mathrm{W}}_{\text {agit }} \cdot \mathrm{t}_{\text {agit }}
$$

Para o cálculo do tempo de operação do agitador $\left(t_{\text {agit }}\right)$, considera-se que este funciona por 2 minutos $\left(\mathrm{t}_{\text {agit, }}\right)$ a cada 15 minutos $\left(\mathrm{f}_{\text {agit }}\right)$, assim:

$$
\mathrm{t}_{\text {agit }}=\frac{\mathrm{t}_{\text {agit }, \mathrm{h}}}{\mathrm{f}_{\text {agit }}} \cdot\left[24-\left(\mathrm{t}_{\text {resf }}+\mathrm{t}_{\text {conserv }}\right)\right]
$$

Considerando a duração das etapas de resfriamento e conservação anteriormente calculadas, o agitador operará 2,27 horas por dia, portanto o seu consumo de energia será de $0,34 \mathrm{kWh} /$ dia.

- Consumo total de energia

Com a somatória do consumo diário das 3 etapas, descritas anteriormente, determina-se o consumo anual de energia elétrica da configuração $\mathrm{N}^{\circ} 01\left(\mathrm{~W}_{\text {conf,01 }}\right)$, como sendo de 7.353,94 kWh. O custo de operação é aquele decorrente do consumo de eletricidade da rede pública, cujo valor no setor rural, segundo as tarifas de 2006 da Agência Nacional de Energia Elétrica (ANEEL) para a região sudeste é de R \$192,78/MWh (Tab. 7.7). Assim, o custo operacional da instalação será de R\$ $1.417,69$.

Finalmente, considerando que o custo anual de manutenção representa 5\% do custo do equipamento, para um tempo de vida útil de aproximadamente 30.000 horas, esse custo será de $\mathrm{R} \$ 900,00$. 
Tabela 7.7. Tarifas médias para o setor rural.

\begin{tabular}{cc}
\hline Região & R\$/MWh \\
\hline N & 204,69 \\
NE & 165,55 \\
SE & 192,78 \\
S & 144,21 \\
CO & 195,95 \\
Brasil & 167,91 \\
\hline
\end{tabular}

Fonte: ANEEL, 2006

\subsubsection{Configuração $\mathrm{N}^{\circ} 02$}

Nesta configuração será analisado um grupo gerador ciclo Otto acionado por biogás para geração da energia elétrica necessária à operação da UCCV (Fig. 7.4).

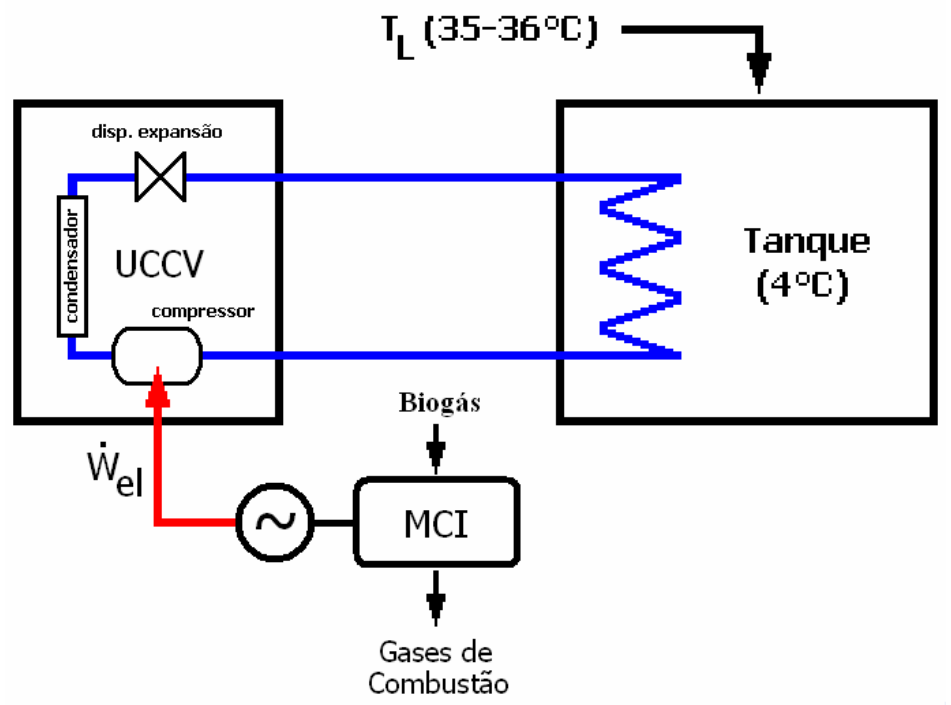

Figura 7.4. Esquema da configuração $\mathrm{N}^{\circ} 02$ 


\section{- Seleção do equipamento}

Levando em conta que a unidade de refrigeração é a mesma considerada na configuração $\mathrm{N}^{\circ} 01$, foi selecionado um grupo gerador de produção nacional cujas características, para operação com gasolina, estão indicadas na Tab. 7.8.

Tabela 7.8. Dados técnicos do grupo gerador ciclo Otto

\begin{tabular}{ccc}
\hline Componente & Característica & Valor \\
\hline \multirow{4}{*}{ Motor } & $\mathrm{N}^{\circ}$ cilindros & 1 \\
& Cilindrada $\left(\mathrm{cm}^{3}\right)$ & 389 \\
& Tipo arrefecimento & ar \\
& Combustível & gasolina \\
& Consumo de gasolina $(\mathrm{kg} / \mathrm{kWh})$ & 0,31 \\
& Potencia máxima do motor $(\mathrm{kW}) @ 3.600 \mathrm{rpm}$ & 9,5 \\
\multirow{4}{*}{ Gerador } & Rotação $(\mathrm{rpm})$ & 3.600 \\
& Fases & Monofásico \\
& Pólos & 2,00 \\
& Potência máxima $(\mathrm{kW})$ & 5,5 \\
& Carregador de baterias $(12 \mathrm{~V})$ & sim \\
\hline
\end{tabular}

Diversas oficinas especializadas na conversão de motores a gasolina para gás natural veicular (GNV) foram consultadas com o intuito de estimar o custo adicional para conversão do motor do grupo gerador selecionado, e esse custo seria da ordem de R\$ 500,00 (MARQUEZ, 2006), por se tratar de um motor estacionário de pequeno porte em que a alimentação pode ser feita a baixa pressão (pressão do biodigestor), dispensando assim o sistema redutor de pressão e de armazenamento a alta pressão necessários na conversão de um motor para aplicações veiculares.

Para a determinação do consumo de biogás, é considerada uma queda de $10 \%$ na potência do motor, e em função da diferença entre os PCI da gasolina e do biogás, o consumo do motor após a conversão é determinado pela Eq. 7.36. 


$$
\dot{\mathrm{m}}_{\text {biogás }}=\left(\frac{\mathrm{FC}_{\text {gasolina }} \times \mathrm{PCI}_{\text {gasolina }}}{\mathrm{PCI}_{\text {biogás }}}\right) \times(1-\mathrm{FPP}) \cdot \dot{\mathrm{W}}_{\text {motor }}
$$

Da equação anterior foi determinado um fator de consumo de $0,59 \mathrm{~m}^{3} / \mathrm{kWh}$, próximo ao utilizado por Piccinini et al. (1996) para operar um motor de $15 \mathrm{~kW}$ alimentado por biogás com $65 \%$ de metano $\left(0,58 \mathrm{~m}^{3} / \mathrm{kWh}\right)$, bem como dentro da faixa $\left(0,5\right.$ a $\left.0,8 \mathrm{~m}^{3} / \mathrm{kWh}\right)$ recomendada por Werner et al. (1989).

\section{- Geração de energia elétrica}

Considerando a queda de potência pela substituição da gasolina, o grupo gerador será capaz de gerar a plena carga uma potência elétrica nominal de 4,87 kW a 3.600rpm, com uma eficiência mecânica de $26,4 \%$ e elétrica de $17 \%$.

\section{- Custo de operação e manutenção do grupo gerador $\left(\mathrm{C}_{O \& M}\right)$}

Como comentado ao final do item 7.5.1, o custo do biogás pode ser considerado nulo, e portanto os custos de operação para essa configuração estarão inteiramente associados às tarefas de manutenção.

Por se tratar de um motor a ciclo Otto modificado para operar com biogás, e devido a que é operado poucas horas por dia (etapa de resfriamento e conservação do leite), os serviços de manutenção deverão ser aprimorados a fim de evitar a diminuição do tempo de vida útil (WALSH et al, 1988; MITZLAFF, 1988). Piccinini et al. (1996) afirma que, sob operação continua e manutenção rigorosa, equipamentos montados e testados em fabrica conseguiram trabalhar até 30.000 horas.

Assim, para um tempo de vida do projeto de 10 anos (ou 23.000 horas aproximadamente) são considerados dois serviços, a manutenção programada e a preventiva. Por conta de serem diversas as considerações sobre as rotinas de manutenção e os custos associados, da revisão da literatura se constataram que as variações de caso para caso são significativas. 
Com base nessa literatura e custos praticados em oficinas especializadas, estimou-se que o custo de manutenção programada é da ordem de $15 \%$ do custo de investimento do equipamento, incluído o custo da conversão ( $\mathrm{R} \$ 474,00)$. Esse custo corresponde às tarefas periódicas de manutenção (limpeza, calibração, troca de óleo e filtros, entre outras).

Costa (2006), a partir do catalogo de um fabricante de motores a biogás considera que o serviço de manutenção preventiva deva ser realizado a cada 5.000 horas, e com um custo que representa $1 / 3$ do investimento inicial. Isto representa um custo de $\mathrm{R} \$ 1.053,33$ a cada 2 anos, dado que o equipamento opera em média 2.550 h/ano.

\subsubsection{Configuração $\mathrm{N}^{\circ} 03$}

Nesta configuração é analisado um grupo gerador acionado por uma mistura combustível constituída por diesel/biogás para acionamento do sistema de refrigeração considerado na configuração $\mathrm{n}^{\circ} .01$ (Fig. 7.5).

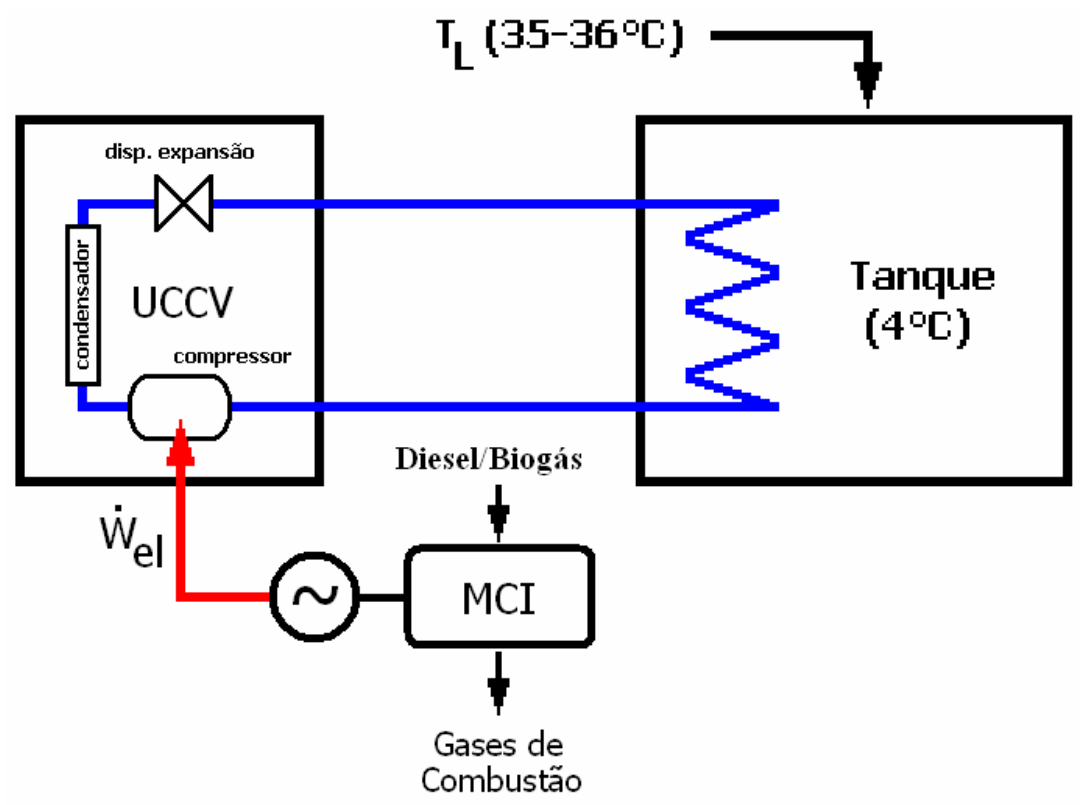

Figura 7.5. Esquema da Configuração $\mathrm{N}^{\circ} 03$ 


\section{- Seleção do equipamento}

Levando em conta que a unidade de refrigeração é a mesma considerada na configuração $\mathrm{N}^{\circ}$ 01, foi selecionado um grupo gerador de produção nacional cujas características, para operação com diesel, estão indicadas na Tab. 7.9.

Como mencionado anteriormente (seção 4.2.2), a conversão de um motor a diesel para operar com mistura diesel/biogás passa pela modificação do sistema de alimentação, com tal finalidade uma câmara de mistura é instalada na entrada de ar de combustão.

Os custos para conversão do equipamento para trabalhar com uma mistura biogás-diesel pode ser considerado similar ao adotado na configuração anterior (R \$ $500,00)$, por conta da semelhança nas modificações.

Tabela 7.9. Dados técnicos do moto-gerador a diesel.

\begin{tabular}{ccc}
\hline Componente & Característica & Valor \\
\hline \multirow{4}{*}{ Motor } & $\mathrm{N}^{\circ}$ cilindros & 1 \\
& Cilindrada $\left(\mathrm{cm}^{3}\right)$ & - \\
& Tipo arrefecimento & ar \\
& Combustível & diesel \\
& Consumo de combustível $(\mathrm{kg} / \mathrm{kWh})$ & 0,26 \\
& Potencia máxima do motor $(\mathrm{kW}) @ 3500 \mathrm{rpm}$ & 7,35 \\
\hline \multirow{3}{*}{ Gerador } & Fases & Monofásico \\
& Pólos & 2,00 \\
& Potência máxima $(\mathrm{kW})$ & 5 \\
& Carregador de baterias $(12 \mathrm{~V})$ & sim \\
\hline
\end{tabular}

\section{- Geração de energia elétrica}

Diversos trabalhos (MITZLAFF, 1988; SILVA, 1995; WERNER et al., 1989, NAN et al., 1994) indicam que o comportamento de um motor diesel não é afetado pela substituição de até $85 \%$ do diesel por biogás. Segundo isso, a partir dos dados 
do fabricante (eficiência total e consumo específico de combustível) e para um fator de substituição (FS) de 60\% do óleo diesel, determinou-se, por meio da Eq. 7.37 o consumo de combustível da unidade. Sendo da ordem de 10,68 $\mathrm{m}^{3} / \mathrm{dia}$ e 4,38 1/dia para o biogás e o diesel, respectivamente.

$$
\dot{\mathrm{V}}_{\text {biogás }}=\frac{\mathrm{FS}_{\text {diesel }} \cdot \dot{\mathrm{m}}_{\text {diesel }} \cdot \mathrm{PCI}_{\text {diesel }}}{\mathrm{PCI}_{\text {biogás }}}
$$

Esse consumo de combustível corresponde à uma potência de $6,62 \mathrm{~kW}$ a $90 \%$ da carga máxima (3.5000 rpm), com uma eficiência elétrica de 26,6\%, suficiente para suprir a demanda do tanque de resfriamento.

\section{- Custo de operação e manutenção do grupo gerador ( Co\&M$\left._{\text {O\& }}\right)$}

Os custos de operação estão associados apenas ao consumo de diesel, uma vez que, como já mencionado, o custo do biogás pode ser considerado nulo. Da mesma forma que no caso anterior é considerado que o grupo gerador opera no período de resfriamento e conservação do leite (cerca de 7 horas ao dia), e assim, na condição de operação prevista o consumo anual de diesel seria de 1.600 litros. Considerando um preço médio ponderado do óleo diesel de R \$ 1,80/litro (ANP, 2006 ${ }^{7}$ ), o custo anual seria de $\mathrm{R} \$ 2.879,47$.

Por conta da utilização parcial de biogás, considera-se que o custo de manutenção deste equipamento corresponde às taxas aplicadas na configuração anterior, sendo de $\mathrm{R} \$ 547,50 /$ ano e $\mathrm{R} \$ 1.383,33 /$ biênio, para a manutenção periódica e reparação, respectivamente.

7 Preços médios de revenda de óleo diesel em nível regional. Fonte: Relatório Mensal de Acompanhamento de Mercado - Maio 2006. Agência Nacional de Petróleo. 


\subsubsection{Configuração $\mathrm{N}^{\circ} 04$}

Nesta configuração é avaliado um chiller de absorção acionado por queima direta de biogás, o resfriamento ocorre em um trocador de placas por onde a água gelada é circulada mediante uma bomba (Fig. 7.6).

\section{- Seleção de equipamento}

Foi notado que no mercado nacional não existe uma cultura de uso do chiller por absorção de pequeno porte para suprir operações de refrigeração industrial, só de ar condicionado. Por isso, foi selecionado um chiller de absorção operado por queima direta de gás natural que eventualmente seria importado por uma firma brasileira. As características estão listadas na Tab. 7.10. O custo de tal equipamento é aproximado e fornecido por uma empresa brasileira de engenharia.

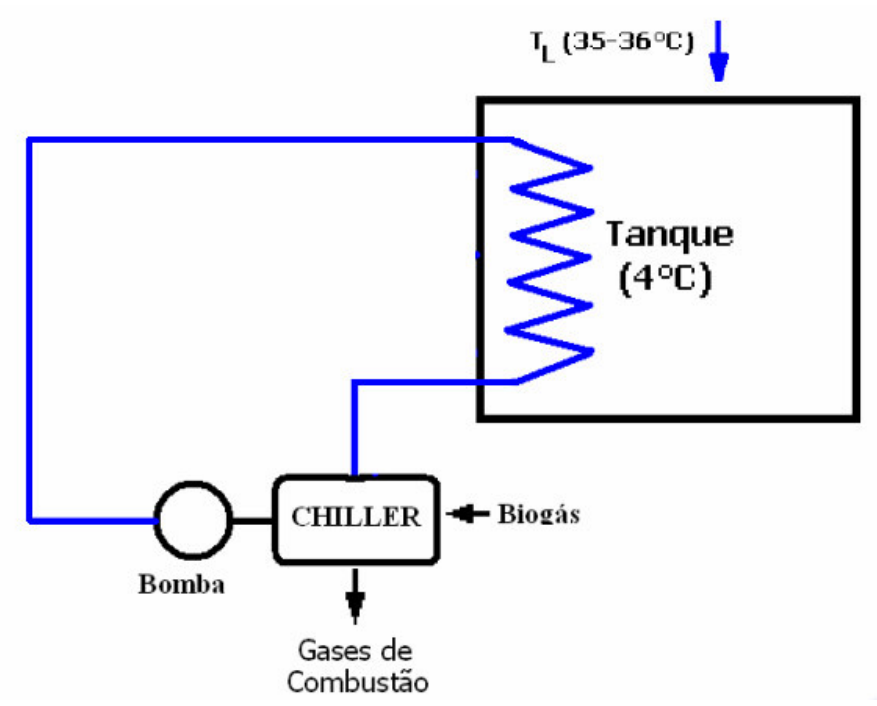

Figura 7.6. Configuração $N^{\circ} 04$ 
Tabela 7.10. Dados técnicos do chiller de absorção

\begin{tabular}{lc}
\hline \multicolumn{1}{c}{ Característica } & Valor \\
\hline Tipo & queima direta \\
Combustível & gás natural \\
Consumo $\left(\mathrm{m}^{3} / \mathrm{h}\right)$ & 2,65 \\
Calor de entrada $(\mathrm{kW})$ & 25,03 \\
Fluido resfriado & Água $+40 \%$ de glicol \\
Vazão mássica nominal de refrigerante $(\mathrm{kg} / \mathrm{h})$ & 2600 \\
Capacidade nominal de resfriamento $(\mathrm{kW})$ & 13,3 \\
Capacidade de resfriamento $(\mathrm{kW})^{*}$ & 13,97 \\
Par absorvente-refrigerante & $\mathrm{H}_{2} \mathrm{O}-\mathrm{Amônia}$ \\
Condensação & $\mathrm{Ar}$ \\
Custo de investimento $(\mathrm{R} \$)$ & $35.000,00$ \\
\hline
\end{tabular}

(*) Capacidade frigorífica para água de entrada a $-5^{\circ} \mathrm{C}$

Ao custo do chiller deve ser adicionado os custos do tanque de armazenamento, que nesse caso utiliza uma serpentina tipo Half-pipe (R \$25.400) e da bomba de circulação de líquido ( $\mathrm{R} \$ 600,00)$, um adicional de $\mathrm{R} \$ 26.000,00$. Dessa forma, o custo total de instalação dessa configuração é de $\mathrm{R} \$ 61.000,00$.

\section{- Custo de operação}

O principal insumo energético para acionamento da unidade de absorção é o biogás. Para o equipamento considerado, levando em conta o consumo de gás natural para uma dada capacidade de refrigeração, o consumo de biogás para se atingir a mesma capacidade pode ser determinado a partir da Eq. 7.38.

$$
\dot{\mathrm{V}}_{\text {biogás }}=\frac{\dot{\mathrm{V}}_{\mathrm{GN}} \times \mathrm{PCI}_{\mathrm{GN}}}{\mathrm{PCI}_{\text {biogás }}}
$$

Assim, como o biogás apresenta um conteúdo energético menor, o consumo da unidade passaria de 2,65 para cerca de $3,9 \mathrm{~m}^{3} / \mathrm{h}$. 
Além do biogás, essa configuração demanda energia elétrica para o acionamento da bomba de água gelada e da bomba de solução da unidade de absorção. Essa energia elétrica pode não estar disponível, e assim seria necessária a instalação de uma unidade geradora, que por sua vez, o que elevaria o custo de instalação e de operação.

Considerando que haja a disponibilidade de energia elétrica, o consumo aproximado da bomba de água e da bomba de solução é de 950 e 1.145,00 kWh/ano, e portanto o custo de operação do sistema em $\mathrm{R} \$ 403,69 /$ ano.

\section{- Custo de manutenção}

O serviço de manutenção considera a manutenção periódica dos componentes móveis da configuração, como a bomba de solução (chiller), a bomba de água gelada e o motor redutor do agitador, assim como do chiller de absorção (queimador), porém devido ao alto grau de incerteza, dada a falta de informação, foi considerado um custo total anual de manutenção de aproximadamente $5 \%$ do custo global de investimento, sendo, portanto de R $\$ 3.050,00$.

\subsubsection{Outras Configurações Analisadas}

Além das configurações apresentadas anteriormente, no desenvolvimento do presente trabalho foram consideradas outras 3 configurações: um moto-gerador movido exclusivamente a diesel, outro movido exclusivamente a gasolina, e um sistema de água gelada composto por um banco de gelo, trocador de placas e uma bomba de circulação de água.

As duas primeiras foram descartadas por utilizarem combustíveis fósseis e apresentarem elevados custos operacionais. Já o sistema de água gelada apresentou elevados custos de instalação e operação, assim como complicações técnicas de operação e manutenção, não sendo portanto competitivo com o tanque de expansão direta. Essas configurações apresentam um custo superior em $100 \%$ às outras aqui avaliadas. 


\subsubsection{Comparação Econômica das Configurações}

A Tabela 7.11 apresenta os custos de investimento, operação e manutenção para cada uma das configurações consideradas (item 7.5.1), bem como uma comparação dos custos totais de cada uma delas, calculados utilizando o método do Valor Presente, descrito no item 6.6.1. Nessa tabela, CO é o custo de operação, CM1 o custo de manutenção do tanque de resfriamento com UCCV, CM2 o custo de manutenção do grupo gerador ou do chiller por absorção e CMT é o custo de manutenção total. Já COH representa o custo de manutenção preventiva.

A taxa de juros considerada corresponde ao programa PROLEITE que é de 8,75\% ao ano (ver item 2.4.2). Esse valor é vigente, é considerado nas cotações feitas por empresas especializadas em equipamento leiteiro.

A tabela mostra que as configurações 2 e 1, na ordem, seriam as mais adequadas para atender ao cenário 1, pois são as que apresentam os menores valores presentes. Cabe ressaltar que, como a análise da configuração $\mathrm{N}^{\circ} 2$ considera várias estimativas relacionadas com a operação do moto-gerador, não é possível afirmar categoricamente que esta representa a melhor opção de investimento, ainda que exista esta tendência. Para tal, a análise deverá ser aprofundada, principalmente na questão relacionada com o serviço de manutenção.

Tabela 7.11. Comparação de custos para o cenário 1

\begin{tabular}{ccccc}
\hline Valores & \multicolumn{4}{c}{ Configurações } \\
$(\mathrm{R} \$)$ & 1 & 2 & 3 & 4 \\
\hline IT & 18.000 & 21.160 & $22.150,00$ & 61.000 \\
CO & $1.417,69$ & 0,0 & $2.879,47$ & 403,69 \\
CM1 & 900,00 & 900,00 & 900,00 & - \\
CM2 & & 474,00 & 622,50 & $3.050,00$ \\
CMT & 900,00 & $1.374,00$ & $1.522,50$ & $3.050,00$ \\
COH & 0,00 & $1.053,30$ & $1.383,33$ & 0,00 \\
\hline VP & $33.039,24$ & $32.667,87$ & $54.118,15$ & $83.410,61$ \\
\hline
\end{tabular}




\subsubsection{Custo de Resfriamento do Leite}

Ao longo do tempo de vida do projeto o custo médio de resfriamento do leite pode ser determinado a partir do valor presente calculado para cada uma das configurações e da produção anual de leite. Esse custo representa mais uma ferramenta que pode ser utilizada na definição da melhor opção a ser implementada para o resfriamento do leite.

Para uma produção anual de 305.000 litros de leite foi determinado qual o custo de resfriamento do litro de leite segundo a Eq. 7.36 para as diversas configurações, e os resultados estão na Tab. 7.12.

$$
\mathrm{CRU}_{\text {leite }}=\frac{\mathrm{VP}_{\mathrm{x}}}{\mathrm{V}_{\text {leite } \mathrm{T}}}
$$

$\mathrm{Na}$ equação anterior, VP é o valor presente da configuração em questão e

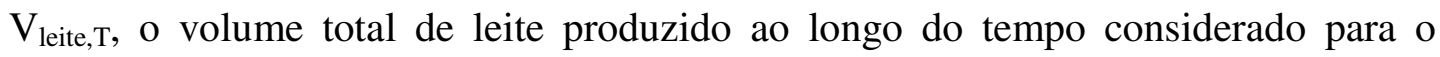
projeto (10 anos). De forma análoga ao item 7.5.1.5, as configurações nos. 01 e 02 apresentam o menor custo unitário, e a diferença entre elas é menor que $1 \%$.

Considerando às questões ambientais e a não disponibilidade de energia da rede, o moto-gerador operado com biogás surge como alternativa atraente para suprir o resfriamento do leite. Para tanto, é implementada a análise de investimento mediante o método TIR (item 6.5.2). Dessa forma, considerando um preço médio de leite de R\$ 0,52/litro, para as 5 maiores bacias leiteiras (CEPEA, 2005) e uma taxa conservadora de $5 \%$ como incentivo econômico ao resfriamento do leite na fazenda (SANT'ANNA et al., 2003), obteve-se uma TIR de 26\%. Os ganhos econômicos pagariam o investimento em aproximadamente 4 anos. Por sua vez, os ganhos em qualidade do leite, garantiriam ou permitiriam a negociação de um novo contrato de compra-venda de leite com a empresa coletora ou laticínio. 
Tabela 7.12. Análise de custos para o cenário 1

\begin{tabular}{ccccc}
\hline Valores & \multicolumn{4}{c}{ Configurações } \\
$(\mathrm{R} \$)$ & 01 & 02 & 03 & 04 \\
\hline $\mathrm{VP}$ & $33.039,24$ & $32.667,87$ & $54.118,15$ & $83.410,61$ \\
$\mathrm{CRU}_{\text {leite }}$ & 0,0108 & 0,0107 & 0,0177 & 0,0273 \\
\hline
\end{tabular}




\subsubsection{Cenário 2}

Este cenário analisa a viabilidade da substituição da compra de energia elétrica, necessária para o acionamento de um tanque de resfriamento de leite já existente na fazenda, por um sistema de geração de energia in loco, utilizando o biogás como insumo energético, uma vez que, com a inclusão da fazenda em um projeto MDL de digestão anaeróbica, esse insumo energético estará disponível a custo zero para o produtor.

A análise desse cenário será realizada com base nos resultados do cenário 1 , que mostra que a geração de eletricidade a partir da queima de biogás em um grupo gerador ciclo Otto é uma melhor opção que um grupo gerador ciclo Diesel com mistura biogás-diesel.

Dessa forma, considera-se como configuração existente A um tanque resfriador semelhante ao da configuração $\mathrm{N}^{\circ} 01$. que apresenta um custo operacional de $\mathrm{R} \$$ 1.397,50/ano. Dado que o tanque resfriador é um equipamento comum às duas alternativas, os custos de manutenção foram desconsiderados, uma vez que existiriam em ambas as situações.

Além disso, está sendo considerado que o tempo de vida do projeto é menor ao tempo de vida útil do tanque (15 anos aproximadamente).

Ao se introduzir a configuração alternativa B (grupo gerador ciclo Otto), há um custo de investimento de $\mathrm{R} \$ 3.160,00$, e custos de manutenção programada e preventiva de $\mathrm{R}$ \$ 474,00/ano e $\mathrm{R} \$ 1.053,33 /$ biênio, respectivamente.

A análise econômica, apresentada na Tab. 7.13, utiliza os métodos de Valor Presente e Economia de Ciclo de Vida, descritos no Capítulo 6, considerando uma taxa de juros de $8,75 \%$ e um tempo de vida do projeto de 10 anos. 
Tabela 7.13. Comparação de custos do cenário 2.

\begin{tabular}{ccc}
\hline Valores (R\$) & Configuração A & Configuração B \\
\hline IT & 0,00 & $3.160,00$ \\
CO & $1.417,69$ & 0,00 \\
CM2 & 0,00 & 474,00 \\
COH & 0,00 & $1.053,33$ \\
\hline VP & $9.199,24$ & $9.054,69$ \\
\hline ECV & \multicolumn{3}{c}{144,55} \\
\hline
\end{tabular}

Tanto a análise de VP quanto a de ECV indicam que, por uma margem muito pequena, o motor-gerador representa a melhor alternativa de investimento. Contudo, devido aos cálculos estarem baseados em estimativas, considera-se que é indiferente mudar ou continuar com o atual sistema, pois não há um ganho que justifique categoricamente o retrofit da instalação. Já a análise pela taxa interna de retorno indica um valor de TIR de 43\%, com um tempo de retorno de investimento de 27 meses (2,25 anos).

É importante destacar que está sendo analisada apenas a substituição da energia elétrica para o sistema de resfriamento por energia gerada in loco. A possibilidade de geração de uma quantidade maior de energia para atender a outras demandas da fazenda, como a operação de sistemas de ordenha e de bombeamento, deve muito provavelmente aumentar a atratividade dessa substituição. É necessário aprofundar o estudo nesse sentido. 


\section{CONCLUSÕES E RECOMENDAÇÕES}

Os novos tempos exigem o desenvolvimento sustentável das atividades econômicas do homem para garantir a subsistência de gerações futuras, razão pela qual maiores esforços devem ser canalizados no desenvolvimento de pesquisas para o aprimoramento e/ou desenvolvimento de sistemas térmicos que auxiliem às atividades agropecuárias, uma área "verde", porém potencialmente poluidora se medidas não forem adotadas para o gerenciamento dos detritos gerados.

Como descrito nos capítulos anteriores, no intuito de fortalecer a participação do produtor leiteiro dentro da cadeia produtiva do leite, conseguiu-se estabelecer uma modelagem que visualiza quais as alternativas tecnológicas que podem ser adotadas pelo produtor leiteiro para resfriar o leite na fazenda, e assim satisfazer as exigências do Programa Nacional de Melhoria da Qualidade do Leite (PNQL).

A quantificação da redução de emissões de GEE, permitiu demonstrar que a instalação de biodigestores para o adequado gerenciamento dos detritos animais produzidos numa fazenda de pequeno e médio porte pode gerar retribuições econômicas se incluídas em projetos de MDL coletivos, que vem despertando o interesse e já sendo promovidos por investidores internacionais, especialmente na suinocultura. A tendência para o período de 2008-2012, no qual as exigências do Protocolo de Kyoto deverão ser cumpridas, é que o preço do crédito de carbono venha a duplicar ou mesmo triplicar.

A análise de cenários indicou que a utilização do biogás em um sistema de geração de energia elétrica acionado por motor de combustão de ciclo Otto com o intuito de atender a demanda do sistema frigorífico de conservação do leite cru é técnica e economicamente viável para o cenário 1, sendo a melhor opção onde não há disponibilidade de energia elétrica. Onde essa disponibilidade existe, essa opção 
apresenta viabilidade econômica semelhante à de um tanque com acionamento "convencional" por energia elétrica da rede, ficando a critério do fazendeiro optar por uma configuração com menor custo inicial e maior custo operacional (acionamento "convencional") ou uma com investimento maior e custo operacional menor (acionamento com gerador).

Além disso, quando um produtor de leite tipo $\mathrm{C}$ implementa um sistema de resfriamento de leite na fazenda, ele passa a produzir leite tipo B, passando dessa forma a receber mais da empresa coletora. Considerando que as retribuições econômicas vindas do resfriamento do leite, variam e dependem diretamente dos termos contratuais realizado entre o produtor e a empresa coletora, o valor adicional pago por litro de leite pode chegar a $\mathrm{R} \$ 0,20 /$ litro (incentivo de $40 \%$ ), principalmente para cooperativas com grandes volumes de produção de leite.

A análise mostrou que este ganho, para a escala de produção aqui estudada, seria suficiente para financiar a instalação de um tanque de expansão operado com energia elétrica gerada a partir da queima de biogás em um moto-gerador ciclo Otto.

Em relação ao cenário 2, os resultados indicam, apesar das incertezas nas estimativas dos custos de manutenção, que a substituição da compra de energia elétrica por geração in loco é uma alternativa interessante, ainda que apresente um tempo de retorno de investimento (2,25 anos) relativamente elevado para os padrões brasileiros.

Uma dificuldade encontrada no desenvolvimento do presente foi a falta de colaboração dos fabricantes e/ou fornecedores dos equipamentos analisados, principalmente na disponibilização das suas características técnicas e tarefas programadas de manutenção.

Como recomendação de trabalhos futuros pode-se destacar a realização de um estudo semelhante a esse para analisar outras demandas energéticas que poderiam ser atendidas pelo biogás para melhor utilizar o insumo energético disponível, e conseqüentemente melhorar a atratividade econômica da implantação das configurações baseadas em sistemas de geração de energia in loco. Nessa linha, seria 
interessante analisar a viabilidade de sistemas de micro-cogeração para atender demandas combinadas de frio/calor e potência.

Outro estudo que se recomenda como continuidade deste trabalho é a implementação de um protótipo de pequeno porte para atender as necessidades levantadas nesta dissertação, visando validar experimentalmente os resultados obtidos. Algumas das empresas contatadas no desenvolvimento do trabalho manifestaram o interesse de eventualmente formar parcerias com a Universidade para essa implantação.

Adicionalmente, os resultados deste trabalho podem ser utilizados como um pré-estudo de viabilidade para a implantação de um centro de resfriamento coletivo (cooperativa) para um conjunto de pequenos produtores de leite. O tamanho de rebanho aqui avaliado corresponde a cerca de 20 associados com 50 litros/dia cada.

A redução de emissões seria basicamente a mesma, desde que biodigestores de baixo custo seriam instalados em cada uma das propriedades. Para esse caso a operação do tanque com energia elétrica da rede seria a melhor opção, já que o abastecimento com biogás de um moto-gerador seria inviabilizado por conta das distâncias entre propriedades. Esse biogás, porém, poderia ser utilizado para iluminação e cozimento de alimentos. 


\section{REFERÊNCIAS BIBLIOGRÁFICAS}

ABREU, A.F. Sistema de refrigeração por absorção intermitente: concepção, dimensionamento, construção, ensaio e considerações econômicas. 1999. 236 p. Tese (Doutorado) - Instituto Interunidades de Electrotécnica e Energia (IEE) da Universidade de São Paulo, São Paulo 1999.

ADD Consultoria. Mercado de carbono, 2006. Disponível em: $<$ http://www.addconsultoria.com>. Acesso em: 29 maio 2006.

AGÊNCIA NACIONAL DE ENERGIA ELÉTRICA (ANEEL). Referência Janeiro de 2006. Dispovível em: <http://www.aneel.gov.br/98.htm>. Acesso em: 07 maio 2006.

AGÊNCIA NACIONAL DE PETRÓLEO (ANP). Relatório mensal de acompanhamento de Mercado. Coordenadoria de Defesa da Concorrência (CDC), Maio de 2006.

AGSTAR Digest 2002. Disponível em: <http://www.epa.gov/agstar/pdf/2002digest.pdf > . Acesso em: 10 agos. 2005.

AHRING, B.; ANGELIDAKI, I. Monitoring and controlling the biogas process. In: Proceedings of the Eighth International Conference on Anaerobic Digestion, vol. 1, p. 40-50, 1997.

ALANNE, K.; SAARI, A. Sustainable small-scale CHP technologies for buildings: the basis for multi-perspective decision-making. Renewable and Sustainable Energy Reviews, v. 8, p. 401-431. 2004

ALEGRE, J. A.V. Simulação de processos e análise exergética do motor de ciclo diesel. 1993. Tese ( Doutorado) Engenharia Mecânica- Universidade Estadual de Campinas, Fundação de Amparo à Pesquisa do Estado de São Paulo. São Paulo, 1993.

ALFA-LAVAL, 1990. Manual de industrias lácteas. Segunda Edición. AMV Ediciones Mundi Prensa.

AN, B. X. et al. Installation and performance of low-cost polyethylene tube biodigesters on small-scale farms. Livestock Research for Rural Development, v.9, n.2, 1997. 
AN, B. X. The role of low-cost plastic tube biodigesters in integrated farming systems in Vietnam (Part I). SECOND FAO ELECTRONIC CONFERENCE ON TROPICAL FEEDS Livestock Feed Resources within Integrated Farming Systems.1997.

BALESTIERI, J.A.P. Cogeração: geração combinada de eletricidade e calor. UFSC: Florianópolis, 279 p .2002

BALSAM, J. Anaerobic digestion of animal wastes: factors to consider. Appropriate Technology Transfer for Rural Areas, U.S. Department of Agriculture. Disponível em: <www.attra.ncat.org >. Acesso: 20 jun. 2005.

BARI, S. Effect of carbon dioxide on the performance of biogas/diesel duel-fuel engine. Renewable Energy, v.9, p. 1007-1010, 1996.

BAYER M.M; MARINHO, J.N; PANNIERSELVAM, P.V. Estudo de engenharia de processo e custo para valorização de biogás via cogeração de energia auxiliado por computador. In: CONGRESSO BRASILEIRO DE ENGENHARIA QUÍMICA, XIII., 2000, São Paulo. Anais ... Águas de São Pedro, São Paulo. 2000

BENINCASA, M.; ORTOLANI, A.F.; LUCAS JR., J. Biodigestores convencionais. Faculdade de Ciências Agrárias e Veterinárias - UNESP, Jaboticabal, 25 p.1990

BNDES. Efeito estufa e a convenção sobre mudança do clima. Banco Nacional de Desenvolvimento Econômico e Social. 1999. Disponível em: $<$ http://www.mct.gov.br/clima/quioto/bndes.htm>. Acesso em 20 fev. 2006.

BRUNACCI, A. Brasil lança primeiro pregão de carbono na América Latina. Ministério do Desenvolvimento, Industria e Comercio Exterior. Disponível em: $<$ http://www.desenvolvimento.gov.br/sitio/ascom/noticias/noticia.php?cd_noticia=66 51>. Acesso em: 06 fev. 2006.

BURKE, D. Dairy Waste Anaerobic Digestion Handbook, Options for Recovering Beneficial Products From Dairy Manure, Minnesota Department of Agriculture. Disponível em: <http://www.mda.state.mn.us/feedlots/digester.htm. $>$ Acesso em: 20 mar. 2004.

CAETANO, L. Proposição de um sistema modificado para quantificação de biogás. 1985. Dissertação (Mestrado). Fac. de Cs. Agronômicas do campus Jaboticabal da Universidade Estadual Paulista (UNESP). Botucatu, 1985.

CARVALHO, L.A.; NOVAES, L.P.; GOMES, A.T.; MIRANDA, J.E.C.; RIBEIRO, A. C.C.L. Sistema de Produção de Leite (Zona da Mata Atlântica). Empresa Brasileira de Pesquisa Agropecuária: sistemas de produção, 2003. Disponível em: $<$ http://sistemasdeproducao.cnptia.embrapa.br/FontesHTML/Leite/LeiteZonadaMata Atlantica/importancia.html>. Acesso em: 10 ago. 2006.

CAVIDAD, A. Utilización del biogas para generación de electricidad. Fundación CIPAV. Disponível em: <http://www.cipav.org.co/>. Acesso em: 2 mar. 2005. 
CEPEA . Preços ao produtor cem antes do previsto. Centro Especializado em Pesquisas Agrícolas - ESALQ. Disponível em: <www.cepea.esalq.usp.br>. Acesso em: jul de 2005.

CHAMBERS, A. K.; POTTER, I. Gas Utilization from Sewage Waste. Carbon and Energy Management. Alberta Research Council Edmonton, Alberta, (T6N 1E4) Canada 2002.

COSTA, D. Geração de energia elétrica a partir do biogás de tratamento de esgoto. 2006. 194 p. Dissertação (Mestrado). Instituto Interunidades de Electrotécnica e Energia (IEE) da Universidade de São Paulo, São Paulo, 2006.

DELAVAL . Porque resfriar o leite. Informações Técnicas da DeLaval. Disponível em: <http://www.delaval.com.br>. Acesso em: 10 nov. 2005.

ECONERGY. Carbon Market. Newsletter ago. 2006. Disponível em: http://www.econergy.com/Asp/DisplayPDF.Asp?NUMBER=250. Acesso em: 05 set. 2006.

EMBRAPA. Informe econômico do leite. Empresa Brasileira de Pesquisa Agropecuária- Comissão Nacional de Pecuária de leite (CNPL). Ano 3, n. 3, abr. 2003.

EMBRAPA. O leite de que o Brasil precisa. Empresa Brasileira de Pesquisa Agropecuária. Disponível em: <www.cnpgl.embrapa.com.br>. Acesso em: 05 jun. 2005.

EMBRAPA. Produção, industrialização e comercialização. Empresa Brasileira de Pesquisa Agropecuária, 2006a. Disponível em: $<$ http://www.cnpgl.embrapa.br/producao/producao.php>. Acesso em: 28 ago. 2006.

EMBRAPA. Sistemas de tratamentos de dejetos suínos: inventario tecnológico. Empresa Brasileira de Pesquisa Agropecuária, 2006. Disponível em: < http://www.cnpsa.embrapa.br/invtec/09.html>. Acesso em: 20 jun. 2006.

EMBRATER. Encontro sobre Biogás Automotivo para a Empresa Rural, 1984, Empresa de Assistência Técnica e Extensão Rural, Londrina, 73p.

ESQUIVEL, R., et al. O. Important features of the introduction of biodigesters in small scale dairy farms. Livestock Research for Rural Development, v.14, n.3 2002.

FAO. Diseño de una Estrategia Regional para la Promoción y Desarrollo de Alianzas Productivas. Food and Agriculture Organization of the United Nations: conferencias electrónicas, 2004. Disponível em: http://www.rlc.fao.org/foro/alianza/. Acesso em: 15 ago. 2006.

FARINA, E.M.M.Q. et al. Private and public milk standars in Argentina and Brazil. Food Policy, n. 30, p. 302-315,2005. 
FULFORD, D. J., 1984. Use of dual-fuel engines with biogas in Nepal. Inst of Energy, p. 133-139.

GAMEZ, M., 2006. Os bilhões do carbono. Isto é, 16 de ago. 2006.

GASPAR, R. B. L. Utilização de biodigestores em pequenas e médias propriedades rurais com ênfase na agregação de valor: um estudo de caso na região de Toledo-PR. Programa de Pós-Graduação em Engenharia de Produção e Sistemas. Florianópolis, 2003.

GENEROSO, F.B. Quantificação e caracterização de dejetos produzidos em propriedade com exploração leiteira para uso em biodigestores e reciclagem de nutrientes. 2001. 66 p. (Trabalho apresentado para obtenção de graduação em zootecnia) - Faculdade de Ciências Agrárias e Veterinárias, Universidade Estadual Paulista, Jaboticabal, 2001.

GONÇALVES, R. Gerente da área de resfriadores de leite da empresa INCOMAR. Cotação de tanque para resfriamento de leite [Conversação pessoal] jul. 2006.

GRUPO PLANTAR. Projetos Créditos de Carbono: o projeto Plantar, 2006. Disponível em: $<$ http://www.plantar.com.br/portal/page?_pageid=73,332306\&_dad=portal\&_schem a=PORTAL>. Acesso em: 20 ago. 2006.

GUIMARÃES, S. Brasil ocupa a liderança mundial com 74 projetos baseados em MDL. Valor Econômico n. 90198, 2005. Disponível em: $<$ http://infoener.iee.usp.br/infoener/hemeroteca/imagens/90198.htm>. Acesso em: 24 fev. 2005.

GUSTAVSSON, M. Biogas Technology : solution in Search of Its Problem, A Study of Small-Scale Rural Technology Introduction and Integration. Section Human Ecology Dept. Interdisciplinary Studies Göteborg University., 2000.

HARRIS, P. L. Beginners Tour of Biogas. Disponível em: $<$ http://www.roseworthy.adelaide.edu.au/ pharris/biogas/beginners.html $>$. Acesso em: 13 mar. 2005.

HENHAM A., MAKKAR, M.K. Combustion of simulated biogas in a dual-fuel diesel engine. Energy conversion management, v.39, n.16-18, p. 2001-2009, 1998.

HIGHAM, I. Economics of anaerobic digestion of agricultural waste. Technical Summary. AEA Technology Environment, 1998.

INTERGOVERNMENTAL PANEL FOR CLIMATE CHANGE (IPCC). Guidelines for national greenhouse gas inventories : Reference Manual, 1996.

JALURIA, Y. Design and optimization of thermal system. McGraw Hill, Singapore. 1998. 
JANK, F.S. Gestão da Pecuária Leiteira : sob Medida para o Brasil. Revista Agroanalysis, v.18, n 6 p.20-23, Jun. 1998.

JASH T.; BASU S. Development of a mini-biogas digester for lighting in India. Energy, v.24, p. 409-411, 1999.

JAWUREK, H. H.; LANE, N. W.; RALLIS, C. J. Biogas/petrol dual fuelling of si engine for rural third world use. Biomass, v.13, n .2, p 87-103, 1987.

JAWUREK, H. H.; RALLIS, C.J. Biogas-fuelling of small engine-alternator set for rural applications. In: Proceedings of the Intersociety Energy Conversion Engineering Conference, p. 670-674, 1984.

JENSEN, J. Carbon Credits: New Opportunities Carbon Credits: New Opportunities for U.S. Livestock Industry, AgSTAR National Conference, 2006. Disponível em $<$ http://www.epa.gov/agstar/pdf/conf06/jensen.pdf>. Acesso em : 20 ago. 2006

JENSEN, J. K.; JENSEN, A. B. Biogas and natural gas fuel mixture for the future. First World Conference and exhibition on biomass for energy and industry, Sevilla, 2000.

JEWELL, W. J. et al. Cogeneration of electricity and heat from biogas. New York : Dept. of Energy, Solar Energy Research Instituite, 1986. (Report for science and education Administration)

JONSSON ,O. Biogas upgrading and use as transport fuel. Swedish Gas Centre, $2004 . \quad$ Disponível em: $<$ http://websrv2.tekes.fi/opencms/opencms/OhjelmaPortaali/Kaynnissa/Streams/fi/D okumenttiarkisto/Viestinta_ja_aktivointi/Seminaarit/2004/9-9-2004/6-biogas.pdf $>$. Acesso em: 2 out. 2005.

KHANG, D. N.; TUAN, L. M. Transfering the low cost plastic film biodigester technology to farmers. Proceedings Biodigester Workshop 2002. Disponivel em: <www. Mekarn.org/procbio/khang2.htm>. Acesso em: 30 abr. 2005.

KISAALITA, W. Professor associado do Departamento de Engenharia Biológica e Agrícola da Universidade de Geórgia. Refrigeração por absorção e o resfriamento do leite [Conversação pessoal], 2004.

LEITE BRASIL. A origem do drama do leite. Associação Brasileira dos Produtores de Leite, 2001. Disponível em: <http://www.leitebrasil.org.br/artigos.htm>. Acesso em: 06 fev. 2006.

LIBORIO, I.T. Bases do Mecanismo de desenvolvimento limpo. Jusgentium, Angra dos Reis, 2005. Disponível em: <www.jusgentium.com/2005030702.pdf.> Acesso em: 18 fev. 2006.

LIMA, M. A. Agropecuária brasileira e as mudanças climáticas globais: Caracterização do problema, oportunidades e desafios. Cadernos de Ciência \& Tecnologia, Brasília, v.19, n. 3, p.451-472, set./dez. 2002. 
Lima, M. A.; Pessoa, M. C. P. Y.; Ligo, M. A.V. Primeiro inventário brasileiro de emissões antrópicas de gases de efeito estufa: Emissões de metano da pecuária. Ministério da Ciência e Tecnologia (MCT), 2006. Disponível em: < http://www.mct.gov.br/upd_blob/8806.pdf>. Acesso em: 10 maio 2006.

MACHADO, P. L. O. A. Soil carbon and the mitigation of global climate change. Quím. Nova, v. 28, n .2, p. 329-334, mar./abr. 2005.

MAGALHÃES E. A; at al. Confecção e avaliação de um sistema de remoção do CO2 contido no biuogás. Acta Scientiarum Technology, v. 26, n. 1, p. 11-19, Maringá, 2004.

MAIDMENT, G.G.; PROSSER, G. The use of CHP and absorption cooling in cold storage. Applied Thermal Engineering, v. 20, p. 1059-1073, 2000.

MAPA. Ministério de Agricultura, Pecuária e Abastecimento, 2002.

MÁRQUEZ, C. Engenheiro da CM Racing. Conversão de motores de combustão interna para biogás. [Comunicação pessoal] 2006.

MARTINS C. M. Competitividade da cadeia produtiva do leite no Brasil. Revista de Política Agrícola, Ano XIII, n. 3 , p. 38-51, jul./ago./set. 2004.

MARTINS, P. Pagamento por qualidade no Brasil: motivações e obstáculos. 2004. Disponível em: <www.milkpoint.com.br>. Acesso em: 10 out. 2005.

MASSOTTI, Z. Viabilidade técnica e econômica do biogás ao nível de propriedade. Epagri - Concórdia, SC, 2003.

MEARS, D.T. Biogas Applications for Large Dairy Operations: alternatives to conventional Engine-Generators. Cornell Cooperative Extension Association of Wyoming County, USA, 102 p., 2001.

Ministério das Minas e Energia (MME). PROINFA: Programa de Incentivo às Fontes Alternativas de Energia. [S.1:s.n], 2005. Disponível em:<http:/www.mme.gov.br/programs display.do?prg=5>. Acesso em: 17 fev.2005.

MIRANDA, N.M. Innovación Tecnológica para el enfriamiento de leche em proyectos de micro e pequena escala. Disponível em: <http://webs.advance.com.ar/friotecnologia/pmle.htm>. Acesso em: 5 fev. 2004.

MITZLAFF, K. V. Engines for biogas. Deutsche Gesellschaft für Technische Zusammenarbeit (GTZ) GmbH, Eschborn 1988.

MOOG, F. A. at al. Promotion and utilization of polyethylene biodigester in smallhold farming systems in the Philippines. Livestock Research for Rural development, v. 9, n. 2, 1997.

MOSER, M. Resource potential and barriers facing the development of anaerobic digestion of animal waste in California. (Report 500-93-039) 1997. 
MOUSTAFA, A.; EL HAGGAR, S.M.; GAD EL MAWLA, A. matching of an anaerobic animal waste digester with a dual-fuel generator unit. Int. J. Environment and pollution, v.12, n.1, p. 97-103. 1991.

MURPHY, J. D., MCKEOGH, E., KIELY, G. Technical/economic/environmental analisys of biogás utilisation. Applied energy, 77, 407-427, 2004.

NAN, L.; BEST, G.; CARVALHO N. C. C. Integrated energy systems in China The cold northeastern region experience: livestock house and biogas system, Rome, 1994. Disponível em: <www.fao.org/docrep/t4470e/t4470e00.htm\#contents>. Acesso em: 08 maio 2006.

NERO et al. Leite cru de quatro regiões leiteiras brasileiras: Perspectivas de atendimento dos requisitos microbiológicos estabelecidos pela Instrução Normativa 51. Ciênc. Tecnol. Aliment.,Campinas, v. 25 , n.1, p. 191-195, 2005.

OLIVEIRA JR, S. et al. Sistemas de refrigeração por absorção. Escola Politécnica da USP, São Paulo, 2004.( Apostila).

ORTOLANI, A.F.; BENINCASA, M.; LUCAS JR., J. Biodigestores rurais modelos indiano, chinês e batelada. Jaboticabal: FUNEP, 35 p. 1991.

PENSA. Competitividade no Agribusiness Brasileiro. Programa De Estudos Dos Negócios Do Setor Agroindustrial. São Paulo, 1998. Disponível em: <http://www.pensa.com.br/>. Acesso em: 15 fev. 2005.

PENSA. Mapeamento do sistema agroindustrial do leite. Programa De Estudos Dos Negócios Do Setor Agroindustrial São Paulo, 2005. Disponível em: $<$ http://www.pensa.com.br/>. Acesso em: 15 fev. 2006.

PERDOMO,C.C.; OLIVEIRA, P.A. Valorize os dejetos animais: use o biodigestor. Embrapa Suínos e Aves. Folder. 2000.

PICCININI, S.; FABBRI, C; RIVA, G. Biogas use in pig breeding: Sizing and installation of cogenerators in italy. CRPA e ENEL, out. 1996.

PRESTON T.R., RODRIGUEZ J. L. Recycling of livestock excreta; an essential feature of sustainable farming systems in the tropics. Food and Agricultural Organization of the United Nations (FAO): Recycling Livestock Wastes, 1996. Disponível em: <http://www.fao.org/ag/aga/agap/frg/Recycle/recycle/recycle.htm.> Acesso em: 21 maio 2006.

PRESTON, T.R.; RODRÍGUEZ, L. Low-cost biodigesters as the epicenter of ecological farming systems. In: Proceedings Biodigester Workshop March 2002. Disponível em: <http://www.mekarn.org/procbiod/contents.htm>. Acesso em: 25 jun 2005.

RECOLAST. Manual do biodigestor: construção e funcionamento de biodigestores com geomembranas de PVC. Disponível em: http://www.recolast.com.br. Acesso em: 20 jun. 2006. 
REUTERS. Vacas, chuteiras e geladerias serão alvo de Kyoto. Agência de notícias internacional, 2005.2 Disponível em: $<$ http://www.tcm.rj.gov.br/hp/saibamais_a.asp?Noticia=1783>. Acesso em: 24 fev. 2005.

RIVA, G. Utilization of renewable energy sources and energy-savings technologies by small-scale milk plants and collection centres. [ s.l.] : Food and Agriculture Organization , 1992. 111p. (FAO animal production and health paper; 93)

RODRIGUEZ J. L., PRESTON T.R., LAI V. N. Integrated farming systems for efficient use of local resources. In: Proceedings of the Internet Conference on Integrated Bio-Systems, $1998 . \quad$ Disponível em: $<\mathrm{http}: / / \mathrm{www}$.ias.unu.edu/proceedings/icibs/rodriguez/paper.htm>. Acesso em: 10 oct. 2004.

ROSTAND, R. Revista Virtual Aonde Vamos - Boletim Enfoque, n.15. 2004. Disponível em: <http://www.aondevamos.eng.br/boletins/edicao15.htm>. Acesso em: 3 mar. 2005.

RUBAB, S.; KANDPAL T., C. A methodology for financial evaluation of biogas technology in India using cost functions. Biomass and Bioenergy, v.10, n.1, p. 11-23, 1996.

RUCKER, C., BAZZO, E. Análise termodinâmica de um sistema compacto de cogeração utilizando microturbina a gás natural. Revista Petro \& Química, 257/fev. 2004

SANT'ANNA, D.; SILVA, C. A.; GOMES, S. T. Risk analysis of investiments infarm milk cooling tanks. Revista de Economia e Sociologia Rural, v. 41, n. 2, Brasilia abr/jun. 2003.

SBRISSIA, G. F.; PONCHIO, L. A. Sistema Agroindustrial do Leite Brasileiro: Situação atual, mudanças e perspectivas. Publicação Cepea/Esalq-USP. Out. de 2004.

SGC-SWEDISH Gás Centre. Disponível em: <www.sgc.se>. Acesso em 15 set. 2005.

SHIAVI, S. M. A. Relatório setorial preliminar: Setor Lácteo, 21 jun. 2005. Disponível em: <www.finep.gov.br> . Acesso em: 01 nov. 2005.

SILVA, F. M. Sistema de alimentação de motores com duplo combustível - metano e diesel. 1995.Tese (Doutorado) - Departamento de Engenharia Mecânica da Universidade de São Paulo. Escola de Engenharia de São Carlos, São Paulo, 1995.

SINGH, K. J.; SOOCH, S. S. Comparative study of economics of different models of family size biogas plants for state of Punjab, India. Energy conversion and management, n.45, p. 1329-1341, 2004. 
SOARES et al. A Digestão Anaeróbia no tratamento de efluentes de origem bovina: viabilidade em explorações da Beira Litoral e Entre Douro e Minho. Cernas, Escola Superior Agrária de Coimbra, 2005.

SOGARI, N. Cálculo de la producción de metano generado por distintos restos orgânicos. Universidad Nacional Del Nordeste. Comunicaciones cientificas y tecnologicas 2003.

Souza, J.C.V.B. Biodigestor é indicado para geração de crédito de carbono. Empresa Brasileira de Pesquisa Agropecuária - EMBRAPA, 2005. Disponível em: < http://www.embrapa.br/noticias/banco_de_noticias/index_htm>. Acesso em: 10 nov. 2005.

TUSZYNSKI, W. B; DIAKOWSKA; HALL, N. S. Solar energy in small-scale milk processing collection and processing. n. 39, 1983. 116 p. (series - FAO Animal Production and Health Paper).

VEIGA DOS SANTOS, M.; FONSECA, L. Granelização e resfriamento do leite e seu impacto sobre a qualidade do leite e derivados. n. 71, jul. 2003. Disponível em: http://www.dipemar.com.br/leite/71/materia_atecnico_leite.htm. Acesso em: 15 maio 2006.

VERÁSTEGUI, J; MATERO, M. Producción de biogás a partir de desechos orgánicos: estudio de casos de manejo ambiental. Lima, 1979. Disponível em: $<$ http://www.oas.org/usde/publications/unit/oea27s/begin.htm\#Contents $>$. Acesso em: 03 mar. 2004.

VILELA, D. Leite: bom para a saúde e melhor ainda para a economia brasileira. Embrapa Gado de Leite. Disponível em: www.cnpgl.embrapa.br. Acesso em 15 out. 2005.

WALSH, J. L. at al. Handbook on biogas utilization. U.S Deparment of Energy, Alabama, 1988.

WERNER, U.; STÖHR, U.; HEES, N. Biogas plants in animal Husbandry. A Publication of the Deutsches Zentrum für Entwicklungstechnologien _ GATE , a Division of the Deutsche Gesellschaft für Technische Zusammenarbeit (GTZ) GmbH, 1989.

WRITGH, P. Overview of Anaerobic Digestion Systems for Dairy Farms , Natural Resource, Agriculture and Engineering Service (NRAES-143), Mar. 2001.

ZICARI, S. Removal Of Hydrogen Sulfide From Biogas. 2003. 115 p. Thesis (Master) - Faculty of the Graduate School, Cornell University. Wyoming, 2003. 


\section{ANEXO A A INSTRUÇÃO NORMATIVA 51}

Neste anexo são apresentados alguns pontos de destaque da IN51 para melhor entender o relacionado com a legislação vigente no relacionado à qualidade do leite. O documento completo pode ser encontrado em:

- http://www.terraviva.com.br/servicos_legislacoes.htm\#instrucao.agricultura

- http://www.baldebranco.com.br/estatistica.htm

- http://www.cnpgl.embrapa.br/

\section{A.1. REgulamento TÉCNICO DE PRODUÇÃo, IDENTIDADE E QUALIDADE DE LEITE TIPO A}

Entende-se por Leite Pasteurizado tipo A o leite classificado quanto ao teor de gordura em integral, padronizado, semidesnatado ou desnatado, produzido, beneficiado e envasado em estabelecimento denominado Granja Leiteira, observadas as prescrições contidas no presente Regulamento Técnico;

Imediatamente após a pasteurização o produto assim processado deve apresentar teste qualitativo negativo para fosfatase alcalina, teste positivo para peroxidase e enumeração de coliformes a $30 / 35^{\circ} \mathrm{C}$ (trinta/trinta e cinco graus Celsius) menor do que 0,3 NMP/mL (zero vírgula três Número Mais Provável / mililitro) da amostra.

Designação (denominação de venda):

- Leite Pasteurizado tipo A Integral;

- Leite Pasteurizado tipo A Padronizado;

- Leite Pasteurizado tipo A Semidesnatado;

- Leite Pasteurizado tipo A Desnatado; 
Deve constar a expressão Homogeneizado na rotulagem do produto, quando for submetido a esse tratamento, nos termos do presente Regulamento Técnico.

\section{A.2. REgulamento TÉCNICO DE PRODUÇÃO, IDENTIDADE E QUALIDADE DO LEITE TIPO B}

Entende-se por Leite Cru Refrigerado tipo B o leite classificado quanto ao teor de gordura como integral, refrigerado em propriedade rural produtora de leite e nela mantido pelo período máximo de $48 \mathrm{~h}$ (quarenta e oito horas), em temperatura igual ou inferior a $4^{\circ} \mathrm{C}$ (quatro graus Celsius), que deve ser atingida no máximo 3h (três horas) após o término da ordenha, transportado para estabelecimento industrial, para ser processado, onde deve apresentar, no momento do seu recebimento, temperatura igual ou inferior a $7^{\circ} \mathrm{C}$ (sete graus Celsius).

Entende-se por Leite Pasteurizado tipo B o leite classificado quanto ao teor de gordura como integral, padronizado, semidesnatado ou desnatado, submetido à temperatura de 72 a $75^{\circ} \mathrm{C}$ (setenta e dois a setenta e cinco graus Celsius) durante 15 a 20s (quinze a vinte segundos), exclusivamente em equipamento de pasteurização a placas, dotado de painel de controle com termo-registrador computadorizado ou de disco e termo-regulador automáticos, válvula automática de desvio de fluxo, termômetros e torneiras de prova, seguindo-se resfriamento imediato em equipamento a placas até temperatura igual ou inferior a $4^{\circ} \mathrm{C}$ (quatro graus Celsius) e envase no menor prazo possível, sob condições que minimizem contaminações;

Imediatamente após a pasteurização o produto assim processado deve apresentar teste qualitativo negativo para fosfatase alcalina, teste positivo para peroxidase e enumeração de coliformes a 30/350C (trinta/trinta e cinco graus Celsius) menor que 0,3 NMP/ml (zero vírgula três Número Mais Provável/ mililitro) da amostra.

Designação (denominação de venda):

- Leite Cru Refrigerado tipo B;

- Leite Pasteurizado tipo B Integral; 


\section{A.3. REgulamento TÉCNICO DE PRODUÇÃo, IDENTIDAde E QUALIDADE DO LEITE TIPO C}

Entende-se por Leite Cru tipo C o leite não submetido a qualquer tipo de tratamento térmico na fazenda leiteira onde foi produzido e integral quanto ao teor de gordura, transportado em vasilhame adequado e individual de capacidade até 501 (cinqüenta litros) e entregue em estabelecimento industrial adequado até as 10:00 h (dez horas) do dia de sua obtenção;

Entende-se por Leite Cru Refrigerado tipo C o Leite Cru Tipo C, após ser entregue em temperatura ambiente até as 10:00 h (dez horas) do dia de sua obtenção, em Posto de Refrigeração de leite ou estabelecimento industrial adequado e nele ser refrigerado e mantido em temperatura igual ou inferior a $4^{\circ} \mathrm{C}$ (quatro graus Celsius);

\section{A.4. REGULAMENTO TÉCNICO DE IDENTIDADE E QUALIDADE DE LEITE CRU REFRIGERADO}

Entende-se por Leite Cru Refrigerado, o leite refrigerado e mantido nas temperaturas constantes da tabela 2 do presente Regulamento Técnico, transportado em carro-tanque isotérmico da propriedade rural para um Posto de Refrigeração de leite ou estabelecimento industrial adequado, para ser processado.

Designação (denominação de venda): Leite Cru Refrigerado.

Composição e Qualidade:

- Aspecto e Cor: líquido branco opalescente homogêneo;

- Sabor e Odor: característicos. O Leite Cru Refrigerado deve apresentar-se isento de sabores e odores estranhos.

Requisitos gerais: Ausência de neutralizantes da acidez e reconstituintes de densidade.

\section{A.5. REgULAMENTO TÉCNICO DE IDENTIDADE E QUALIDADE DE LEITE PASTEURIZADO}


Leite Pasteurizado é o leite fluido elaborado a partir do Leite Cru Refrigerado na propriedade rural, que apresente as especificações de produção, de coleta e de qualidade dessa matéria-prima contidas em Regulamento Técnico próprio e que tenha sido transportado a granel até o estabelecimento processador;

O Leite Pasteurizado definido neste Regulamento Técnico deve ser classificado quanto ao teor de gordura como integral, padronizado a $3 \% \mathrm{~m} / \mathrm{m}$ (três por cento massa/massa), semidesnatado ou desnatado, e, quando destinado ao consumo humano direto na forma fluida, submetido a tratamento térmico na faixa de temperatura de 72 a $75^{\circ} \mathrm{C}$ (setenta e dois a setenta e cinco graus Celsius) durante 15 a 20s (quinze a vinte segundos), em equipamento de pasteurização a placas, dotado de painel de controle com termo-registrador e termo-regulador automáticos, válvula automática de desvio de fluxo, termômetros e torneiras de prova, seguindo-se resfriamento imediato em aparelhagem a placas. 


\section{ANEXO B A INSTRUÇÃO NORMATIVA 53}

Neste anexo são apresentados alguns pontos de destaque da IN53 para melhor entender o relacionado com a seleção e operação de tanques de resfriamento de leite. O documento completo pode ser encontrado em:

- http://www.terraviva.com.br/servicos_legislacoes.htm\#instrucao.agricultura

- http://www.engetecno.com.br/legislacao/leite_tanques_refr_granel.htm

\section{B.1. REGULAMENTO TÉCNICO PARA FABRICAÇÃO, FUNCIONAMENTO E ENSAIOS DE EFICIÊNCIA DE TANQUES REFRIGERADORES DE LEITE A GRANEL}

Este Regulamento Técnico Nacional especifica determinadas exigências para o projeto, construção e desempenho de tanques refrigeradores para leite a granel e os respectivos métodos de teste.

Este Regulamento Técnico Nacional se aplica a tanques refrigeradores para leite a granel, com controle automático, destinados à instalação fixa em fazendas ou pontos de coleta de leite, e se aplica somente a tanques de duas ordenhas (24h) ou de quatro ordenhas (48h).

O desempenho de um tanque será especificado de acordo com a seguinte classificação:

- Número de ordenhas

- O numeral "2" designa um tanque de duas ordenhas;

- o numeral "4" designa um tanque de quatro ordenhas. 
- Temperatura ambiente

\begin{tabular}{ccc}
\hline Código & $\mathrm{TD}\left({ }^{\circ} \mathrm{C}\right)$ & $\mathrm{TOS}\left({ }^{\circ} \mathrm{C}\right)$ \\
\hline $\mathrm{A}$ & 38 & 43 \\
$\mathrm{~B}$ & 32 & 38 \\
$\mathrm{C}$ & 25 & 32 \\
\hline
\end{tabular}

A temperatura de operação depende da temperatura de desempenho (TD), que representa a temperatura ambiente a ser usada ao medir o grau de resfriamento do leite, e a temperatura operacional segura (TOS), que é o limite mais alto da variação de temperatura ambiente na qual o equipamento deve funcionar.

- Tempo de refrigeração do leite

\begin{tabular}{ccc}
\hline & \multicolumn{2}{c}{ Tempo de resfriamento em horas } \\
Classificação & $\begin{array}{c}\text { Todas as ordenhas } \\
\left(35 \mathrm{a} 4^{\circ} \mathrm{C}\right)\end{array}$ & $\begin{array}{c}\text { Segunda ordenha } \\
\left(10 \mathrm{a} 4^{\circ} \mathrm{C}\right)\end{array}$ \\
\hline I & 2,5 & 1,25 \\
II & 3,0 & 1,5 \\
III & 3,5 & 1,75 \\
IV & $*$ & $*$ \\
\hline
\end{tabular}

*O desempenho e as condições pertinentes devem ser fornecidos pelo fabricante, por exemplo, no caso de pré-resfriamento. 


\section{- Capacidade diária}

O sistema de refrigeração, quando operando em temperaturas ambientes entre $5^{\circ} \mathrm{C}$ e a temperatura de desempenho (TD) especificada, deverá ter capacidade suficiente para resfriar o volume nominal de leite em um tanque de duas ordenhas, ou $50 \%$ do volume nominal em um tanque de quatro ordenhas, a cada $24 \mathrm{~h}$, de $35^{\circ} \mathrm{C}$ para $4^{\circ} \mathrm{C}$ e extrair o calor ganho pelo tanque, proveniente de todas as outras fontes.

\section{- Taxa de refrigeração do leite}

Se um tanque de duas ordenhas estiver vazio ou contiver $50 \%$ de seu volume nominal de leite a $4^{\circ} \mathrm{C}$, e $50 \%$ do volume nominal de leite a $35^{\circ} \mathrm{C}$ for adicionado de uma só vez, todo o leite deverá ser refrigerado a $4{ }^{\circ} \mathrm{C}$ dentro do tempo de refrigeração especificado.

Se um tanque de quatro ordenhas estiver vazio ou contiver 25,50 ou $75 \%$ de seu volume nominal de leite a $4^{\circ} \mathrm{C}$, e $25 \%$ do volume nominal de leite a $35^{\circ} \mathrm{C}$ for adicionado de uma só vez, todo o leite deverá ser refrigerado a $4^{\circ} \mathrm{C}$ dentro do tempo de refrigeração especificado.

Se um volume de leite correspondente a uma segunda ordenha for adicionado ao tanque, o volume total de leite deverá ser refrigerado de $10^{\circ} \mathrm{C}$ para $4^{\circ} \mathrm{C}$ dentro do tempo de refrigeração especificado.

As exigências acima serão aplicáveis a temperaturas ambientes entre $5^{\circ} \mathrm{C}$ e a temperatura de desempenho (TD) especificada.

\section{- Armazenagem de leite}

Sob condições operacionais normais, a temperatura média do leite entre os períodos de refrigeração não poderá exceder $4^{\circ} \mathrm{C}$ para tanques de quatro ordenhas e $5^{\circ} \mathrm{C}$ para tanques de duas ordenhas, e nenhuma parte do leite poderá exceder $9^{\circ} \mathrm{C}$. 
Esta exigência será aplicável para temperaturas ambientes entre $5^{\circ} \mathrm{C}$ e a temperatura de desempenho (TD) especificada.

O tanque deverá ter isolamento térmico cuja eficiência será tal que, à temperatura de desempenho (TD) especificada, a taxa de elevação da temperatura média do leite, inicialmente ao redor de $4^{\circ} \mathrm{C}$, não exceda $1^{\circ} \mathrm{C}$ em $4 \mathrm{~h}$ quando o volume nominal fica estacionário.

\section{- Congelamento do leite}

Quando o tanque contiver entre $10 \%$ e $100 \%$ de seu volume nominal e for usado em temperaturas ambientes entre $5^{\circ} \mathrm{C}$ e a temperatura de desempenho (TD) especificada, não deverá haver formação de gelo abaixo do nível de leite nem durante a refrigeração nem durante a armazenagem.

\section{- Agitação do leite}

A operação do agitador não deverá fazer com que o leite extravase quando o tanque contiver qualquer volume de leite até $100 \%$ de seu volume nominal.

Quando um tanque é destinado à coleta direta, isto é, não é necessária agitação extra antes da amostragem, a gordura deverá estar sempre uniformemente distribuída por todo o leite de forma que o conteúdo de gordura das amostras selecionadas aleatoriamente no tanque, em qualquer ocasião, não seja diferente em mais de $0,1 \mathrm{~g}$ de gordura para cada $100 \mathrm{~g}$ de leite.

Quando um tanque não é destinado à coleta direta, o agitador deverá ser capaz de produzir uma distribuição uniforme (veja o parágrafo anterior) de gordura dentro de, no máximo, 2 min. Esta exigência será aplicável quando o tanque contiver qualquer volume de leite entre $10 \%$ e $100 \%$ de seu volume nominal depois da refrigeração a $4{ }^{\circ} \mathrm{C}$ e depois de $6 \mathrm{~h}$ de descanso. No caso de um sistema de agitação periódica, o tempo de descanso deverá ser reduzido para o tempo decorrido entre 
dois períodos sucessivos de agitação. No caso de um sistema de agitação contínua, não é necessário nenhum tempo de descanso.

Estas exigências de desempenho serão alcançadas sem deterioração do leite como, por exemplo, aquela que poderia ocorrer como resultado da formação de espuma ou manteiga. 